\title{
Accounting Conservatism and Bankruptcy Risk
}

\author{
Gary C. Biddle, Mary L. Z. Ma ${ }^{*}$, Frank M. Song \\ Faculty of Business and Economics \\ The University of Hong Kong
}

July 20, 2011

\begin{abstract}
This study presents evidence that unconditional and conditional conservatism help mitigate subsequent bankruptcy risk via their cash enhancing and informational properties. Bankruptcy risk is in turn positively associated with subsequent unconditional conservatism and negatively associated with subsequent conditional conservatism, reflecting auditor and regulator monitoring and managerial career motives. These findings are robust to endogeneity between unconditional and conditional conservatism, conservatism gaming, extreme distress and actual bankruptcy. Combined, these results suggest that accounting conservatism both influences and is influenced by bankruptcy risk, thus lending support to a traditional rationale for conservatism that will help inform ongoing debates regarding conservatism's role as a pervasive trait and tenet of financial accounting.
\end{abstract}

\section{JEL Classification: M41 G32 G33}

Keywords: accounting conservatism; bankruptcy risk; unconditional conservatism; conditional conservatism

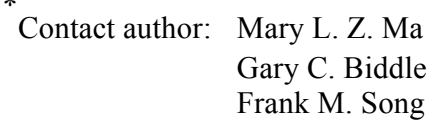

Email: mlizhi@hku.hk

Email: biddle@hku.hk

Email: fmsong@hku.hk

\author{
Telephone number: (852) 2241-5003 \\ Telephone number: (852) 2219-4388 \\ Telephone number: (852) 2857-8507
}

This study derives from Mary Ma's dissertation research at the University of Hong Kong. We thank for their helpful advice and suggestions Sudipta Basu, Kevin Chen, Jinchuan Duan, Dan Givoly, Jens Hilscher, Kai Wai Hui, Mozaffar Khan, Jeong Bon Kim, Anya Kleymenova, Stephannie Larocque, Amy Lau, Ningzhong Li, Xiaohong Liu, Zheng Liu, Yuri Loktionov, Chul Park, Stephen Penman, Xinrong Qiang, Lakshmanan Shivakumar, Anup Srivastava, Zhigang Tao, Kun Yu, Li Zhang, Mingshan Zhang, Xiaojun Zhang and workshop participants at Chinese University of Hong Kong, City University of Hong Kong, University of Hong Kong, Hong Kong University of Science and Technology, London Business School, Moscow School of Management, National University of Singapore, National Taiwan University, Ohio State University, University of Washington, Xiamen University and Yale University. We also thank discussants and participants at the American Accounting Association Annual Meetings in San Francisco, the Financial Accounting Section Meetings in Tampa, the CAPANA Annual Meetings and an anonymous referee. We further appreciate research support from the Asian Case Research Center at the School of Business and the Computer Lab at the School of Economics and Finance of the University of Hong Kong. Any errors remain our responsibility. 


\section{Accounting Conservatism and Bankruptcy Risk}

\section{Introduction}

We examine relations between accounting conservatism and bankruptcy risk and find negative associations between both unconditional and conditional conservatism and subsequent bankruptcy risk that follow from conservatism's accrual nature, cash enhancing and informational properties. Bankruptcy risk is in turn positively related to subsequent unconditional conservatism, consistent with auditor and regulator incentives, and negatively related to subsequent conditional conservatism, consistent with offsetting managerial incentives to withhold bad news. Overall, these findings will help inform ongoing debates regarding conservatism's continuing role as a longstanding tenet and pervasive characteristic of financial accounting.

Evidence that conservatism mitigates bankruptcy risk lends support to a traditional economic rationale for accounting conservatism that it arose at least a millennium ago in response to demands by capital providers to inform lending and liquidation decisions and reduce failure risk (De Ste. Croix (1956), Watts (2003), Basu (2009)). Yet prior empirical evidence is mixed. For example, whereas some studies find conservatism to reduce debt costs and by inference bankruptcy risk others find positive relations between conservatism and debt covenant violations (e.g., Ahmed and Duellman (2002), Zhang (2008), Wittenberg-Moerman (2008) and Li (2010)). We are unaware of any prior study that empirically examines links between accounting conservatism and bankruptcy risk. ${ }^{1}$

Evidence that accounting conservatism lowers bankruptcy risk is also central to the interests of debtholders and other stakeholders who would be adversely affected by firm failure. These stakeholders shareholders (dividends and capital gains), managers and employees (career and compensation), customers (products and services), suppliers (sales), auditors and regulators (compliance) and governments (taxes and financial regulations). This evidence also informs conservatism's role in dampening economic panics, with recent financial crises heightening interest in mechanisms that counter bankruptcy-related contagions across supply chains, sectors and countries (Lang and Stulz (1992), Hertzel et al. (2008), Jorion et al. $(2009)^{2}$

\footnotetext{
${ }^{1}$ Jones (2011) documents that R\&D capitalization increases corporate failures, thus implying that expensing may reduce it. However, R\&D expensing is an extreme form of unconditional conservatism relevant to R\&D-intensive firms that cannot be readily generalized to other types of unconditional and conditional conservatism or firms.

${ }^{2}$ Lang and Stulz (1992) document "contagious" valuation effects of bankruptcy announcements within the same industry. Hertzel et al. (2008) show that bankruptcy filings generate wealth effects for suppliers and customers along the supply chain,
} 
Our findings will also help inform ongoing debates regarding conservatism's continuing role as a pervasive feature and longstanding tenet of financial accounting. In Statement of Financial Accounting Concepts (SFAC) No. 2, the Financial Accounting Standards Board (FASB) defined conservatism as "a prudent reaction to uncertainty to ensure that uncertainty and risks inherent in business situations are adequately considered" (FASB (1980), p. 10). This definition is consistent with conservatism being relevant to assessing bankruptcy risk. However, the FASB and the International Accounting Standards Board (IASB) removed conservatism from their conceptual framework in 2010 for violating neutrality. ${ }^{3}$ In its exposure draft for the Conceptual Framework for Financial Reporting (FASB (2008)), the FASB argued that conservatism may produce information asymmetries that reduce investor insights into future cash flows from growth options. In contrast, Kothari et al. (2010) argue that the broader economic consequences of accounting standards are of first-order significance, while their role in equity valuation is of secondary significance.

Recent studies that document differences between unconditional and conditional conservatism motivate our further examination of how they seperately relate to bankruptcy risk (Beaver and Ryan (2005), Qiang (2007), Ball et al. (2009)). These studies observe that conservatism can arise either "unconditionally" via inherently conservative accounting principles or "conditionally" via a more timely recognition of bad versus good news. Their evidence suggests that unconditional and conditional conservatism can play different roles in contracting, regulation, taxation, valuation and in reducing information asymmetries (Qiang (2007, 2008)), and that they are negatively (positively) correlated in the short (long) run (Beaver and Ryan (2005), Roychowdhury and Watts (2007), Ball et al. (2009)). They further suggest that auditors and regulators focus primarily on unconditional conservatism, litigation risk induces both, and that managers exercise more control over conditional conservatism, at least in the short run, preferring counter-conservative treatments for career advancement (Watts (2003), Qiang (2007), Kothari et al. (2010)).

Our prediction that conservatism reduces subsequent bankruptcy risk is suggested by recent studies of its cash enhancing and informational properties. Specifically, they find that accounting conservatism reduces cash outflows by mitigating capital overinvestment, reducing

and Jorion et al. (2009) provide evidence regarding credit contagions via counter-party effects, suggesting that borrowing firms' bankruptcy announcements cause negative abnormal equity returns and increase credit default swap spreads among creditors.

3 The FASB's Conceptual Framework defines and describes basic concepts by which financial statements are prepared and identifies qualitative characteristics that make information in financial statements useful. It serves as a guide to the Board in developing accounting standards and in resolving accounting issues not addressed directly by an existing standard. The IASB has a corresponding Conceptual Framework. These frameworks were combined into a unified set of accounting concepts and principles in SFAC No. 8 (FASB, 2010). 
risk-shifting, delaying economic losses, promoting precautionary savings and lowering agency costs (Lara et al. (2010a), Callen et al. (2010b), Kirschenheiter and Ramakrishnan (2010), Srivastava and Tse (2010)). Other recent studies find conservatism to increase cash inflows from operations by evoking more favorable terms from trading partners and by paring investment distortions (Hui et al. (2009b), Lara et al. (2010a), Bushman et al. (2010)). These cash enhancing properties of conservatism reduce bankruptcy risk because bankruptcy is fundamentally a condition of cash insufficiency (Kim et al. (1993), Uhrig-Homburg (2005), Campbell et al. (2008)).

Recent evidence also suggests that conservatism lessens information uncertainty and asymmetry via less optimistic reporting of net income and assets and the more timely reporting of bad news (Watts (2003), Guay and Verrecchia (2007)). This informational role of conservatism enhances cash flows and reduces bankruptcy risk as better-informed investors and trading partners provide more favorable financing and contracting terms. Under conditions of distress, conservatism facilitates negotiations and workouts among creditors, equity holders, trading partners, labor unions and other claimants, thus helping avoid bankruptcy filings (Giammarino (1989), Mooradian (1994)). These cash-enhancing and informational properties of conservatism suggest negative causal relations between both unconditional and conditional conservatism and subsequent bankruptcy risk.

That bankruptcy risk might in turn influence subsequent conservatism follows from the reasoning that higher bankruptcy risk induces conservative treatments that will enhance cash and reduce information uncertainty, thus reducing future bankruptcy risk. As bankruptcy risk increases, auditors and regulators pay particular attention to unconditional conservatism as it is the major contributor to total conservatism, is easier to monitor, and is not bad-news-driven ((Ryan (2006), Qiang (2007)). In contrast, managers generally resist both unconditional and conditional conservatism to advance their careers, justify spending and portray more favorable performance, especially when bankruptcy risk increases, with their ability to do so stronger for conditional conservatism. This interaction between auditors' and regulators' interests and managers' career motives suggests that bankruptcy risk will be positively associated with subsequent unconditional conservatism and negatively associated with subsequent conditional conservatism.

These predictions are tested using U.S. firm-year observations for the period 1989-2007 with available data for unconditional and conditional conservatism, bankruptcy risk and control variables. Two of the three bankruptcy risk measures are continuous ex ante estimates derived from Merton (1974) and Campbell et al. (2008), respectively, which permit tests of causal 
relations between accounting conservatism and bankruptcy risk. The third measure is an ex post discrete (zero-one) indicator of actual bankruptcy filings not subject to measurement error. Four measures of unconditional conservatism are considered: total accruals (adapted from Ahmed and Duellman (2007)), rank of industry-adjusted book-to-market ratio (e.g., Ahmed et al. (2002), Zhang (2008)), hidden reserves (Penman and Zhang (2002)), and a factor score from a principal components analysis of the above three metrics. Four measures of conditional conservatism are likewise examined: accumulated non-operating accruals adapted from Zhang (2008), an extended measure of Khan and Watts (2009), a CR ratio measure adapted from Callen et al. (2010a), and a factor score from a principal component analysis of the above three metrics. We mainly employ tri-variate VARX (1) and tri-variate VARX (3) models to examine causal relations between conservatism and bankruptcy risk, extending Lara et al. (2009).

Our main results confirm these predictions: (1) Unconditional and conditional conservatism are negatively associated with subsequent bankruptcy risk, consistent with conservatism's cash enhancing and informational properties serving to mitigate bankruptcy risk, and (2) Bankruptcy risk is positively associated with subsequent unconditional conservatism, consistent with auditors' and regulators' interests, and negatively associated with subsequent conditional conservatism, consistent with countervailing managerial incentives to withhold bad news to advance their careers. These findings are similar for extremely distressed firms and for firms that actually declare bankruptcy.

In further analyses using VARX models with interactions among conservatism, cash holdings and informational properties, we find that both the cash enhancing and informational roles of conservatism help mitigate bankruptcy risk. . We further find that auditor and regulator monitoring increases subsequent unconditional conservatism as bankruptcy risk rises. These results are robust to endogeneity between unconditional and conditional conservatism, extreme distress, actual bankruptcy, conservatism gaming, debt contracting, earnings management, other control variables and alternative measures of unconditional and conditional conservatism and bankruptcy risk.

The remainder of the study is organized as follows: Section 2 details the conceptual framework and hypotheses. Section 3 describes the data and test methodologies. Section 4 presents empirical results and Section 5 concludes. Appendices A and B examine relations among bankruptcy risk and alternate measures of unconditional and conservatism, respectively. 


\section{Theoretical Framework}

Conservatism has been a characteristic of financial accounting for at least a millennium (Basu (2009)). Figure 1 depicts the continuum along which firms evolve from financial health to bankruptcy. Accounting conservatism, by definition, reduces net income and net assets but not cash flows and balances in itself. Bankruptcy, by comparison, is fundamentally a condition of cash insufficiency. Firms can operate indefinitely with reduced or even negative net income without entering either default (Figure 1,T=2) or bankruptcy (Figure 1, $T=3$ ), so long as cash arrives from some source to meet arising obligations. ${ }^{4}$ Conservatism operates in both the "health" and "distress" stages (Figure 1, $T=0,1$ ), as well as the "default" stage (Figure 1, $T=$ $2)$, to enhance cash and transparency regarding net assets and net income, thereby helping avert progressions into ultimate conditions of default or bankruptcy.

\subsection{The Cash Enhancing Role of Accounting Conservatism}

Prior studies suggest that accounting conservatism enhances cash availability by both increasing cash inflows and reducing cash outflows. Conservatism increases cash inflows by promoting precautionary savings, reducing capital costs, alleviating underinvestment and increasing operating cash flows (OCF). Kirschenheiter and Ramakrishnan (2010) argue analytically that prudent decision makers invoke conservative accounting to facilitate decisions regarding precautionary savings as future cash inflows become riskier, thereby increasing (reducing) cash holdings (expenditures). Ahmed and Duellman (2002), Lara et al. (2010b) and Li (2010) document that conservatism lowers the cost of capital and facilitates external financing, thereby increasing reducing capital underinvestment and enhancing future OCF. ${ }^{5}$ Hui et al. (2009b) argue that within some range, conservatism engenders more lenient contracting terms from suppliers, which has the effect of increasing OCF. In a more general setting, BMS (2011) document that both unconditional and conditional conservatism mitigate future OCF downside risk.

Conservatism reduces cash outflows by discouraging cash disbursements, reducing cash wastage and lowering agency costs associated with cash holdings. By delaying net income and

\footnotetext{
${ }^{4}$ Whereas certain creditors monitor funds with broader definitions than cash such as working capital, they are ultimately interested in the cash that working capital provides. Indeed, a firm with ample working capital can be bankrupt due to cash insufficiency if its working capital otherwise is illiquid. Anecdotal evidence suggests that counter-conservatism can also contribute to financial distress. As an illustration, before the 2009 financial crisis, AIG insured financial institutions but did not accrue related contingent liabilities. When the financial crisis arose, AIG experienced large losses and would have been forced into bankruptcy without a government bailout. Similarly, before 2007, subsequently bankrupt GM reported pension assets and liabilities as off-balance-sheet items under SFAS No. 87, rather than as contingent liabilities following SFAS No. 5, since before 2007, SFAS No. 87 allowed firms to report estimated net pension liabilities in footnotes to their financial statements as an exception to the more conservative treatment in SFAS No. 5.

${ }^{5}$ Ahmed and Duellman (2002) provide evidence that conservatism increases the debt ratings, thus lowering interest expenditures as confirmed by Zhang (2008). Lara et al. (2010a) document that conservative accounting reduces the cost of equity capital. $\mathrm{Li}$ (2010) reports that conservatism reduces the cost of both debt and equity capital in a cross-country setting.
} 
net asset recognition, conservatism reduces or defers cash expenditures for performance-based compensation, taxes and dividends (Biddle (1980), Watts (2003), Callen et al. (2010b)). ${ }^{6}$ Lara et al. (2010b) argue that conditional conservatism increases managerial incentives to avoid suboptimal investments ex ante, and to abandon loss projects more quickly ex post (see also Srivastava and Tse (2010)). Bushman et al. (2010) and Francis and Martin (2010) report that timely loss recognition curbs over-investment in cross-country and in acquisition settings, respectively, and Loktionov (2009) argues that in distressed firms, conditional conservatism reduces risk-shifting in investment projects by speeding up technical defaults. Louis et al. (2009) document that timely loss recognition reduces value-destroying agency costs associated with increased cash holdings.

Ultimately, conservatism's cash enhancing role helps mitigate bankruptcy risk because bankruptcy is fundamentally a condition of cash insufficiency as suggested by theories and evidence in finance. Kim et al. (1993), Anderson and Sundaresan (1996) and Uhrig-Homburg (2005)) model bankruptcy as debt default triggered when cash flows available for payouts fall below required debt service payments. Campbell et al. (2008) provide confirming evidence that prior cash holdings are negatively associated with default risk over various prediction horizons from one month to three years. BMS (2011) provide evidence that both unconditional and conditional conservatism are positively associated with the level and upside potentials of cash holdings. Conservatism's cash enhancing role is further supplemented by its informational properties.

\subsection{The Informational Role of Accounting Conservatism}

Prior research suggests that unconditional and conditional conservatism play an informational role that reduces information uncertainties and asymmetries by constraining upward overstatement biases in net income and assets (Watts (2003), Li (2008)) and by revealing bad news in a timely fashion (Lafond and Watts (2008), Wittenberg-Moerman (2008)). Guay and Verrecchia (2007) argue that disclosing lower-end realizations of firm value via ex ante commitments to conservative reporting promotes voluntary disclosures of higher-end realizations, thereby promoting fuller disclosures regarding cash flows and improving information precision. Gox et al. (2009) argue that impairment rules, a type of conditional conservatism, increase information precision. Watts (2003) and Qiang (2008) suggest that both unconditional and conditional conservatism reduce information asymmetry between firms and investors regarding asset values. Hui et al. (2009a) find both unconditional

\footnotetext{
${ }^{6}$ Biddle (1980) and Callen et al. (2010b) provide evidence that LIFO firms reduce taxes by adopting and subsequently managing inventories, and that conservatism discourages or defers dividend payouts, respectively.
} 
and conditional conservatism to substitute for managerial forecasts in reducing information asymmetry and information uncertainty.

This informational role of accounting conservatism reduces bankruptcy risk indirectly by supplementing its cash-enhancing role. By reducing information uncertainties and asymmetries, conservatism reduces adverse selection costs and risks to investors, and the cost of equity and debt capital, thereby increasing cash availability from external sources when firms approach default (Figure 1, Stages 0, 1, and 2). For firms that have entered into conditions of distress (Figure 1, Stages 1 and 2), the informational properties of conservatism help avert rightward progressions into bankruptcy by encouraging creditors, other capital providers and the borrowing firm to work more cooperatively with each other to avoid a bankruptcy filing, at least in the case of unconditional conservatism. Finance theories concur that less information asymmetry facilitates debt renegotiations and reduces bankruptcy filings. In particular, lower information asymmetry stimulates bargaining and multiple reorganization plans (Carapeto (2005)), private debt renegotiations (Chen (2003)) and bankruptcy filings by creditors (Giammarino (1989) and Mooradian (1994)). Thus, conservatism's informational role allows capital providers to be more confident regarding firms' financial conditions and more willing to renegotiate debts and terms, thereby reducing the need for default resolution via bankruptcy filings (Figure 1, Stage 3).

Both the cash enhancing and informational roles of accounting conservatism suggest that unconditional and conditional conservatism lower subsequent bankruptcy risk by increasing cash holdings and flows and by facilitating the avoidance of formal bankruptcy filings by firms in financial distress. This reasoning leads to the prediction that both unconditional and conditional conservatism will be negatively related to subsequent bankruptcy risk:

H1a. Unconditional conservatism is negatively associated with subsequent bankruptcy risk.

H1b. Conditional conservatism is negatively associated with subsequent bankruptcy risk.

\subsection{Relations between Bankruptcy Risk and Subsequent Accounting Conservatism}

If unconditional and conditional conservatism influence subsequent bankruptcy risk as predicted by hypotheses $\mathrm{H} 1 \mathrm{a}$ and $\mathrm{H} 1 \mathrm{~b}$, it follows that bankruptcy risk may influence subsequent conservatism. In this sense, changes in unconditional and conditional conservatism are natural responses to changes in firms' risk dimensions that are facilitated by flexibility in applying generally accepted accounting principles. However, the influences of bankruptcy risk on subsequent conservatism may differ between unconditional and conditional conservatism 
due to the countervailing interests of auditors, regulators and managers. ${ }^{7}$ Auditors and regulators generally prefer more conservatism, especially unconditional conservatism because, as Qiang (2007) argues, they focus more on unconditional than conditional conservatism because it is a major contributor to total conservatism (Ryan 2006), easier to assess via routine audits, and is not conditioned on bad news "shocks" that auditors and regulators wish to avoid responsibility for, especially as bankruptcy risk increases. Under these conditions, managers thus face higher disciplinary costs for not applying unconditional conservatism including job loss, legal sanctions, regulatory penalties, embarrassment and loss of reputation for "book cooking." These interactions between auditor and regulator monitoring and mangers' motives suggest a positive relation between bankruptcy risk and subsequent unconditional conservatism.

Managers generally prefer less conservatism because it constrains their pursuit of career advancement, compensation, perquisites, pet investments, and other opportunistic activities. Managers in distressed firms in particular have strong incentives to overstate earnings and withhold bad news, at least until performance improves or they secure alternative employment (Kothari et al. (2009), Kothari et al. (2010)), and conditional conservatism accords them relatively greater discretion to do so (Qiang (2007), Kothari et al. (2010)). Auditors and regulators on their part are disinclined to "bad news" shocks associated with conditional conservatism that are also costly to continually monitor (Qiang (2007)). Thus, as bankruptcy risk increases, heightened attention by auditors and regulators to unconditional conservatism will motivate managers toward conditional counter-conservatism over which they have greater control, thus implying the following hypotheses:

H2a. Bankruptcy risk is positively associated with subsequent unconditional conservatism.

H2b. Bankruptcy risk is negatively associated with subsequent conditional conservatism.

\section{Data, Measures and Models}

\subsection{Data}

This study utilizes a pooled sample of firm-year observations from NYSE, AMEX and NASDAQ for fiscal years 1989 through 2007 with data obtained from Compustat, CRSP and the Federal Reserve Bank Reports. Ex ante bankruptcy risk measures EDF from Merton (1974) and Campbell following Campbell et al. (2008), are estimated using CRSP and Compustat data. An ex-post bankruptcy risk measure indicating actual bankruptcy, $B A N K$, is obtained from www.bankruptcydata.com. Firm-year observations with missing values for conservatism,

\footnotetext{
${ }^{7}$ Qiang (2007) documents that litigation risk is positively associated with both unconditional and conditional conservatism and thus would not in itself motivate distinguishing between them.
} 
bankruptcy risk, stock price, total assets or net income before extraordinary items are omitted. Since young firms as more prone to bankruptcy, we set a minimum data requirement for accrual-based conservatism measures of two years and employ one-lag specifications for VARX models, so that only firms with less than three-year histories are excluded. We omit post-bankruptcy firm-year observations for firms filing under Chapter 11 of the U.S. Bankruptcy Code since these observations may be incomparable with pre-bankruptcy data. To reduce the effects of outliers, observations in the top and bottom $1 \%$ of the major variables are winsorised, and firms in financial industries (SIC codes 6000-6999) are excluded. The final sample is comprised of 34,897 firm-year observations for 4,621 firms.

\subsection{Measures for Bankruptcy Risk}

Bankruptcy risk is defined as the probability that a firm will liquidate under Chapter 7 or reorganize under Chapter 11 of the U.S. Bankruptcy Code, which are triggered when firms cannot service cash obligations. From among various structural and restrictive form bankruptcy risk models we employ Merton's (1974) EDF measure and a score derived from Campbell et al. (2008) based on their predictive ability and freedom of estimation bias caused by accounting conservatism versus other models (e.g., Altman's (1968) Z-score, Olson's (1980) O-score and Zmijewski's (1984) Z-score). Both EDF and Campbell are ex ante bankruptcy risk measures. We also examine actual bankruptcy, BANK, an ex post measure with no estimation error.

EDF. $E D F$ is the probability that firm's asset value will fall below its liabilities after $T$ years ( $T=$ one year in this study), assuming that the firm's asset value (continuous rate of growth in assets) is log-normally (normally) distributed. Merton's (1974) option-based structural model expresses a firm's market value $\left(V_{E}\right)$ as a call option on the firm's assets $\left(V_{A}\right)$, with a strike price equal to the face value of debt, and time to expiration equal to $T$. Applying the Black and Scholes (1973) formula and Ito's lemma, we estimate EDF as:

$$
\begin{aligned}
E D F_{t} & =\operatorname{prob}\left\{-\left[\ln \left(V_{A, t} / X_{t}\right)+\left(\mu-0.5 \sigma_{A}^{2}\right) T\right] /\left(\sigma_{A} T^{l / 2}\right) \geq \varepsilon_{t+T}\right\} \\
& =N\left(-\left(\ln \left(V_{A, t} / X_{t}\right)+\left(\mu-0.5 \sigma_{A}^{2}\right) T\right) /\left(\sigma_{A} T^{l / 2}\right)\right),
\end{aligned}
$$

where $N$ is the cumulative density function of the standard normal distribution, $X$ is the face value of a firm's debt, $\sigma_{A}$ is the volatility of a firm's assets, and $\mu$ is the instantaneous drift assuming the firm's market value follows geometric Brownian motion. EDF's intuition is that the probability that a firm's assets are insufficient to pay the face value of its debt increases with the firm's debt and asset volatility, and decreases with the firm's assets. 
Merton's (1974) model assumes market efficiency and complete information. ${ }^{8}$ In this study we relax this assumption, allowing accounting conservatism to impact EDF via an accounting input the leverage ratio. If conservatism facilitates external financing and thereby increases the leverage ratio and strike price in the Merton (1974) model, this may lead to an overestimate of $E D F_{t}$. However, this bias is not a serious issue since it runs counter to the predictions of all hypotheses except $\mathrm{H} 2 \mathrm{a}$. Thus, if $\mathrm{H} 1 \mathrm{a}, \mathrm{H} 1 \mathrm{~b}$ and $\mathrm{H} 2 \mathrm{~b}$ are supported, the true relations would be stronger than observed.

Campbell. Campbell is the ranked probability of a firm declaring bankruptcy one month ahead. It is estimated quarterly by a logit model using stock market and quarterly accounting variables following the formula in the last column of Table III in Campbell et al. (2008). We employ the Campbell estimate for the final fiscal quarter in our tests, as follows:

$$
\text { Campbell }_{t}=\exp \left(\text { temp }_{t}\right) /\left(1+\exp \left(\text { temp }_{t}\right)\right)
$$

where temp $_{t}=-9.08-29.67 *$ NIMTAVG $_{t}+3.36 *$ TLMTA $_{t}-7.35 *$ EXRETAVG $_{t}+1.48 *$ SIGMA $_{t}+0.082 *$ Rsize $_{t}-2.40 *$ CASHHMTA $_{t}+0.054 *$ MB $_{t}-0.937 *$ PRICE $_{t}$. Campbell`s intuition is that bankruptcy risk decreases with the predictability of market-based profitability (NIMTAVG), the predictability of excess return relative to S\&P 500 index (EXRETAVG), the market-based liquidity ratio (CASHHMTA) and the stock price (PRICE). Bankruptcy risk increases with the market-based leverage ratio (TLMTA), stock return volatility (SIGMA), the market-to-book equity ratio $(M B)$ and firm size relative to that of the S\&P 500 index (Rsize).

In comparison to Merton (1974) model, the assumptions underlying the restrictive form logit model for Campbell are more relaxed; for example, it allows market inefficiency and information asymmetry between creditors and the firm, and short-term default that can occur before net asset values breach bankruptcy barriers. ${ }^{9}$ Accounting conservatism could bias Campbell upward to some degree by understating net income $\left(N I M T A V G_{t}\right)$ and the liquidity ratio $\left(C A S H H M T A_{t}\right)$ and by overstating total liabilities $\left(T L M T A_{t}\right)$. However, this bias in Campbell, runs counter to the predictions of all hypotheses except $\mathrm{H} 2 \mathrm{a}$, implying true relations stronger than observed for $\mathrm{H} 1 \mathrm{a}, \mathrm{H} 1 \mathrm{~b}$ and $\mathrm{H} 2 \mathrm{~b}$.

BANK. BANK is an indicator equal to one if a firm files for bankruptcy under Chapter 7 or 11 of the U.S. Bankruptcy Code, and zero otherwise. In contrast to EDF and Campbell,

\footnotetext{
${ }^{8}$ Other relevant assumptions include: (1) creditors and managers have symmetric information about firm value and can observe the inputs into the model, (2) default occurs when a firm's asset value drops below its debt obligations at the time of maturity, (3) the default barrier is the exogenously determined fixed face value of debt, and (4) the asset value follows a diffusion process without jumps.

${ }^{9}$ Other relevant assumptions include: (1) default time is unobservable and no longer tied to firm value falling below a prespecified default barrier, (2) default follows an intensity-based process (e.g. Poisson/Cox process) with exogenous latent variables, (3) the probability of default is logistically distributed, i.e., the cumulative probability of default takes a logistic functional form.
} 
which are ex-ante metrics, $B A N K$ is an ex-post bankruptcy risk measure that is free of estimation error and conservatism bias. However, the subsample of firms that actually declare bankruptcy is much smaller and may not be representative of all firms along a bankruptcy risk continuum. Moreover, $B A N K$ does not support an examination of continuous relations between conservatism and bankruptcy risk, and because data may not exist or be comparable following the declaration of bankruptcy, $B A N K$ does not facilitate the testing of causal relationships between bankruptcy and subsequent unconditional and conditional conservatism. We therefore use EDF and Campbell in our main tests.

\subsection{Measures for Unconditional and Conditional Conservatism}

Givoly et al. (2007) advise using multiple conservatism measures because they capture different aspects of conservatism, some with estimation error. Hence, we examine four firmyear measures of unconditional conservatism: $U C_{-} A C C$ (total accruals as adapted from Ahmed and Duellman (2007)), UC_BM (rank of industry-adjusted book-to-market ratio), $U C_{-} R E S$ (hidden reserves), and UC_PCA (a factor score from a principal components analysis of the above three metrics). We likewise examine four firm-year measures of conditional conservatism: $C C_{-} A R$ (extending Khan and Watts (2009)), CC_CR (extending Callen et al. (2010a)), CC_ACM (accumulated non-operational accruals extending Zhang (2008)), and CC_PCA (a factor score from a principal components analysis of the above three metrics), as described below.

UC_ACC. A proxy for unconditional conservatism equal to negative one times the ratio of average total accruals before depreciation to average total assets, both averaged over threeyear periods ending with the current year. Higher total accruals indicate a higher degree of unconditional conservatism by the rationale that conservatism results in persistently negative accruals (Givoly and Hayn (2000), Ahmed and Duellman (2007)). We calculate total accruals as: $\quad$ Total accruals $_{i t}=$ net income before extraordinary items it $_{\text {(Compustat IB) }}$ - operational

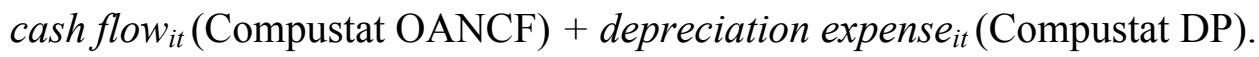

UC_BM. A proxy for unconditional conservatism measured as the industry-adjusted ranking of the product of negative one times the ratio of book value to market value of common shareholders' equity (Ahmed and Duellman (2007), Zhang (2008)). As UC_BM also reflects expected economic rents and future growth opportunities, we use R\&D intensity to control for them following Ahmed and Duellman (2007).

UC_RES. A proxy for unconditional conservatism reflected in "hidden" reserves related to advertising (ADV), research and development (RD) and last-in-first-out inventory 
accounting (INV). Extending Penman and Zhang (2002), this study measures UC_RES as the ratio of hidden reserves to total assets (TA): $U C_{-} R E S_{t}=\left(I N V_{t}^{\text {res }}+R D_{t}^{\text {res }}+A D V_{t}^{\text {res }}\right) / T A_{t}{ }^{10}$

UC_PCA. A proxy for unconditional conservatism measured as the factor score generated from a principal components analysis of the three unconditional conservatism measures $U C_{-} A C C, U C_{-} B M$ and $U C_{-} R E S$. UC_PCA reflects commonalities across these three measures, each with their strengths and weaknesses for measuring UC. Specifically, $U C_{-} A C C$ is an accrual-based metric that does not capture non-accrual unconditional conservatism such as $\mathrm{R} \& \mathrm{D}$ and advertising expenditures. $U C_{-} B M$ is a market-based metric that reflects the understatement of book value relative to market value, as well as expected economic rents and future growth opportunities. UC_RES captures only unconditional conservatism related to hidden reserves. Applying this reasoning, we employ $U C_{-} P C A$ as the primary measure of unconditional conservatism in our main empirical tests.

CC_AR. A proxy for conditional conservatism defined as the ratio of the sum of the $\mathrm{C}$ Score and G Score to G Score from Khan and Watts (2009), a measure of asymmetric response that derives from Basu (1997). Our sampling period, 1989 through 2007, is similar to that examined in Khan and Watts (2009), 1963 through 2005, and our sample size is likewise similar. We use model 2 in Table 3 of Khan and Watts (2009) to estimate $C C_{-} A R_{i t}=$

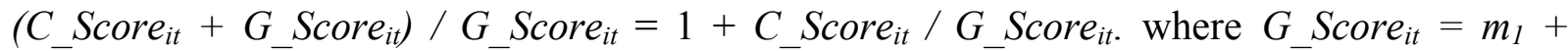
$m_{2}$ Size $_{i t}+m_{3} M / B_{i t}+m_{4} L E V_{i t}=0.237-0.033 *$ Size $_{i}-0.007 * M / B_{i t}+0.033 * L E V_{i t}$ and $C_{-}$Score $_{i t}=l_{1}+l_{2}$ Size $_{i t}+l_{3} M / B_{i t}+l_{4} L E V_{i t}=0.031+0.005 *$ Size $_{i t}-0.006 * M / B_{i t}+$ $0.005 * L E V_{i t}$.

CC_CR. A proxy for conditional conservatism extending Callen et al. (2010a). We estimate $C C \_C R$ as the ratio of current earnings shocks to total earnings news for bad earnings news, with the ratio multiplied by -1 for good earnings news. ${ }^{11}$ This definition differs from the CR ratio in Callen et al. (2010a) in four respects: (1) $C C_{-} C R$ uses the indirect method to estimate earnings news as in Vuolteenaho (2002), (2) CC_CR multiplies the $C R$ ratio by -1 for good earnings news, so that higher $C C_{-} C R$ represents greater conditional conservatism for the good news case, (3) negative observations of CC_CR are not deleted from the sample, (4) intercepts are added to the VAR (1) model for estimating CC_CR.

\footnotetext{
${ }^{10} I N V_{i t}^{\text {res }}$ is the LIFO reserve, $R D_{i t}^{\text {res }}$ is calculated using coefficients in Lev and Sougiannis (1996) to capitalize and amortize $\mathrm{R} \& \mathrm{D}, A D V_{i t}^{\text {res }}$ is advertising expense capitalized and amortized over two years following Bublitz and Ettredge (1989). Penman and Zhang (2002) use net operating assets as the deflator for hidden reserves, but since its value is negative for over one-sixth of our sample, which would potentially bias estimated hidden reserves, we use total assets as the deflator. When data are missing for LIFO reserves, R\&D expensing and advertisement expensing, they are set to zero.

${ }^{11}$ Whereas CC_AR derives from Basu (1997), and its criterion for classifying good versus bad news is whether the associated stock return is positive or negative, $C C \_C R$ derives from Vuolteenaho (2002), and its criterion for classifying good versus bad news is whether $R O E$, earnings scaled by book equity, is greater than the risk-free rate. Additional details regarding the estimation of CC_AR and $C C \_C R$ are available on request.
} 
CC_ACM. A proxy for conditional conservatism measured as negative one times the ratio of accumulated non-operating accruals over a three-year period to accumulated total assets, and is adapted from Zhang (2008). A higher value for $C C_{-} A C M$ indicates a higher level of bad news reported via non-operational accruals. Non-operating accruals are calculated as follows: Nonoperating accruals $=$ Total accruals ${ }^{12}$ - Aaccounts receivable (Compustat RECT) - Ainventories (Compustat INVT) - Aprepaid expenses (Compustat XPP) + Aaccounts payable (Compustat AP) + Dtaxes payable (Compustat TXT).

CC_PCA. A proxy for conditional conservatism measured as the factor score generated from a principal components analysis of the three conditional conservatism measures $C C_{-} A R$, CC_CR and $C C_{-} A C M$. $\quad C C_{-} P C A$ captures commonalities among these three metrics, each with different strengths and weaknesses. Specifically, $C C_{-} A R$ and $C C_{-} C R$ are both marketbased metrics subject to noise from voluntary disclosures of accounting and non-accounting information. CC_AR employs accounting measures that may correlate with bankruptcy risk metrics EDF and Campbell. CC__ACM is an accrual-based metric that captures both bad news in accruals and "big baths" resulting from earnings manipulations and investment accruals. Therefore, we employ $C_{-} P C A$ as the primary measure of conditional conservatism in the main tests.

\subsection{Estimation Models and Methods}

Following Lara et al. (2009), we employ VARX (vector autoregressive with exogenous variables) models to test causal relationships between the two types of conservatism and bankruptcy risk. VARX models are estimated using seemingly unrelated regression (SUR), which improves efficiency when estimating systems of equations with correlated random errors by controlling for cross-equation correlations and when cross-equational error terms are small they approximate OLS. Because prior studies (e.g., Ryan (2006)) suggest that unconditional and conditional conservatism can be substitutes to some degree, we use a tri-variate VARX (1) model consisting of equations (3) to (5) to examine the causal relations between unconditional and conditional conservatism and bankruptcy while controlling for the endogeneity between the two types of conservatism, wherein hypotheses $\mathrm{H} 1 \mathrm{a}, \mathrm{H} 2 \mathrm{a}, \mathrm{H} 1 \mathrm{~b}$ and $\mathrm{H} 2 \mathrm{~b}$ predict $\gamma_{11}<0, \delta_{11}$ $<0, \beta_{21}>0$ and $\beta_{31}<0$, respectively:

$$
\begin{aligned}
& B R_{t}=\alpha_{10}+\beta_{11} B R_{t-1}+\gamma_{11} U C_{-} P C A_{t-1}+\delta_{11} C_{-} P C A_{t-1}+\text { Controls }_{t}+\varepsilon_{11} \\
& U C_{-} P C A_{t}=\alpha_{20}+\beta_{21} B R_{t-1}+\gamma_{21} U C_{-} P C A_{t-1}+\delta_{21} C C_{-} P C A_{t-1}+\text { Controls } \\
&
\end{aligned}
$$

\footnotetext{
${ }^{12}$ Zhang (2008) uses the term "operational accrual", but this term matches the definition of total accruals used in Ahmed et al. (2007). Following Zhang (2008), when cash flow from operations is not available, total accruals are calculated as follows: Total accruals $=$ net income $($ Compustat $\mathrm{NI})+$ depreciation $($ Compustat DP $)-$ funds from operations $($ Compustat FOPT $)+$ $\Delta$ current assets (Compustat ACT) - $\Delta$ debt (Compustat DLC) - $\Delta$ current liabilities (Compustat LCT) - $\Delta$ cash (Compustat CHE).
} 


$$
C C_{-} P C A_{t}=\alpha_{30}+\beta_{31} B R_{t-1}+\gamma_{31} U C_{-} P C A_{t-1}+\delta_{31} C C_{-} P C A_{t-1}+\text { Controls }_{t}+\varepsilon_{31}
$$

where $B R$ refers to bankruptcy risk measures $E D F$ or Campbell and the autoregressive vector includes $B R_{t-1}, U C_{-} P C A_{t-1}$ and $C_{-} P C A_{t-1}$. Controls C $_{t}$ in equation (3) include previously identified determinants of bankruptcy risk(Anderson et al. (1996), Shumway (2001), Parker et al. (2002), Uhrig-Homburg (2005), Campbell et al. (2008), Eberhart et al. (2008)), namely, the leverage ratio $\left(\right.$ Leverage $\left._{t}\right)$, return on total assets $\left(R O A_{t}\right)$, return volatility $\left(S T D_{-}\right.$Ret $\left._{t}\right)$, firm size $\left(\operatorname{Ln}(M V)_{t}\right)$, the risk-free rate $\left(\operatorname{Rate}_{t}\right)$, liquidity $\left(\operatorname{Cash}_{t}\right)$, changes in liquidity $\left(\triangle C a s h_{t}\right)$, and R\&D investment intensity $\left(\right.$ Inten_R $R D_{t}$ ). Consistent with Shumway (2001), Uhrig-Homburg (2004), Campbell et al. (2008) and Eberhart et al. (2008), this study predicts bankruptcy risk to be positively associated with leverage and return volatility and negatively associated with $R O A$, liquidity, cash flow, firm size and the risk-free rate and R\&D investment intensity.

Controls $_{t}$ in equation (4) include previously identified determinants of unconditional conservatism, namely, the leverage ratio $\left(\right.$ Leverage $\left._{t}\right)$, firm size $\left(\operatorname{Ln}(M V)_{t}\right)$ and $\mathrm{R} \& \mathrm{D}$ investment intensity $\left(\right.$ Inten_ $\left.R D_{t}\right){ }^{13}$ These variables proxy for demand for unconditional conservatism arising from contracting considerations, litigation risk, taxation and regulation, while investment intensity Inten_R $R D_{t}$ is used to control for the effects of $\mathrm{R} \& \mathrm{D}$ investment and growth opportunities (Ahmed and Duellman (2007)). Controls $s_{t}$ in equation (5) are the same as in equation (4), but with different predictions. ${ }^{14}$ Lastly, in all the three equations, dummies for the Fama and French (1997) industry classification (Ind_Dum) and fiscal year (Year_Dum) are included to capture fixed industry and year effects.

Because VARX estimation is sensitive to lag structure, with short lags risking wasted information and biased parameters and long lags risking unrepresentative estimates, we employ the following VARX(3) model to test hypotheses H1a, H2a, H1b and H2b:

$$
\begin{aligned}
& B R_{t}=\alpha_{10}+\beta_{11} B R_{t-1}+\beta_{12} B R_{t-2}+\beta_{13} B R_{t-3}+\gamma_{11} U C_{-} P C A_{t-1}+\gamma_{12} U C_{-} P C A_{t-2} \\
& \quad+\gamma_{13} U C_{-} P C A_{t-3}+\delta_{11} C C_{-} P C A_{t-1}+\delta_{12} C C_{-} P C A_{t-2}+\delta_{13} C C_{-} P C A_{t-3}+\text { Controls }_{t}+\varepsilon_{11} \\
& U C_{-} P C A_{t}=\alpha_{20}+\beta_{21} B R_{t-1}+\beta_{22} B R_{t-2}+\beta_{23} B R_{t-3}+\gamma_{21} U C_{-} P C A_{t-1}+\gamma_{22} U C_{-} P C A_{t-2}
\end{aligned}
$$

\footnotetext{
${ }^{13}$ We predict unconditional conservatism to be negatively related with Leverage and $R O A$, and positively related with firm size. Beaver and Ryan (2000) document that leverage is negatively associated with unconditional conservatism because firms with high levels of leverage tend to have greater conflicts between bondholders and shareholders. As ROA increases, firms have less pressure to use unconditionally counter-conservatism to boost earnings. Hagerman and Zmijewski (1979) suggest that firm size proxies for political visibility and because larger firms are more visible, they are subject to higher tax and regulation costs and they are more subject to litigation risk, and Ahmed et al. (2002) document that firm size is positively associated with the unconditional conservatism metrics BM ratio and total accruals.

${ }^{14}$ We predict conditional conservatism to be positively related to Leverage but negatively related to firm size and ROA. Creditors preferring conditional conservatism will have increasing influence over firms as financial leverage increases, especially for firms in financial distress. Well-performing firms have less pressure to use conditional counter-conservatism to boost earnings. Khan and Watts (2009) suggest that larger firms have richer information environments that reduce both overall uncertainty and information asymmetries and thus contracting demand for conditional conservatism; Givoly et al. (2007) and LaFond and Watts (2008) similarly document that the asymmetric timeliness of earnings for large firms is significantly smaller than for small firms.
} 


$$
\begin{gathered}
+\gamma_{23} U C_{-} P C A_{t-3}+\delta_{21} C C_{-} P C A_{t-1}+\delta_{22} C C_{-} P C A_{t-2}+\delta_{23} C C_{-} P C A_{t-3}+\text { Controls }_{t}+\varepsilon_{21} \\
C C_{-} P C A_{t}=\alpha_{30}+\beta_{31} B R_{t-1}+\beta_{32} B R_{t-2}+\beta_{33} B R_{t-3}+\gamma_{31} U C_{-} P C A_{t-1}+\gamma_{32} U C_{-} P C A_{t-2} \\
+\gamma_{33} U C_{-} P C A_{t-3}+\delta_{31} C C_{-} P C A_{t-1}+\delta_{32} C C_{-} P C A_{t-2}+\delta_{33} C C_{-} P C A_{t-3}+\text { Controls }_{t}+\varepsilon_{31}
\end{gathered}
$$

where $B R$ refers to bankruptcy risk measures $E D F$ or Campbell, and the autoregressive vector includes the one- to three- period lags of $B R, U C_{-} P C A$ and $C C_{-} P C A$. Controls used in equations (6) to (8) are the same as those used in equations (3) to (5) wherein H1a predicts $\gamma_{11}$ $+\gamma_{12}+\gamma_{13}<0, \mathrm{H} 2 \mathrm{a}$ predicts $\delta_{11}+\delta_{12}+\delta_{13}<0, \mathrm{H} 1 \mathrm{~b}$ predicts $\beta_{21}+\beta_{22}+\beta_{23}>0$, and $\mathrm{H} 2 \mathrm{~b}$ predicts $\beta_{31}+\beta_{32}+\beta_{33}<0$. We further employ the Akaike Information Criterion (AIC) to identity an optimal lag structure, a goodness of fit measure for estimated models that considers both precision and complexity. It is not a hypothesis test but a tool for model selection. For a given dataset, the competing model with the lowest AIC is considered to have the best fit.

We do not use first-order differencing since Dickey-Fuller tests reveal the major testing variables to be stationary, and when there is no unit root, first-order differencing can generate biased coefficient estimates in VARX models. Sims (1980) and Doan (1992) argue that differencing should not be used even if the variables contain a unit root (i.e., are nonstationary), since the goal of VAR analysis is to determine the inter-relationships among variables, and differencing can destroy information concerning data co-movements. We perform the Dickey-Fuller unit root tests for the unbalanced panel data in this study by running the following regression model for the pooled panel data: $\nabla y_{t}=\delta y_{t-1}+\varepsilon_{i t}$, where $\nabla y_{t}$ is the first differencing of $y$. Then we test the hypothesis H0: $\delta=0 . F$-statistics indicate that the major testing variables are stationary at least at the $99 \%$ confidence level, with results available on request.

\section{Empirical Results}

\subsection{Descriptive Statistics}

Table 1 reports summary statistics (Panel A) and correlation matrices (Panel B) for test variables. In Panel A, the mean of $E D F, 0.0365$, is close to its value reported in Vassalou and Xing (2004) of 0.0420. The mean of UC_ACC, -0.0012, is lower than in Ahmed et al. (2002), 0.003, and in Ahmed and Duellman (2007), 0.010, with this difference likely due to differing sample periods. Ahmed et al. (2002) and Ahmed and Duellman (2007) use samples of S\&P 500 firms during 1993-1998 and 1998-2002, respectively, whereas this study uses NYSE, AMEX and NASDAQ listed firms for 1989-2007. The mean of $C C \_C R$ is -0.3102 , much lower than the $C R$ ratio in Callen et al. (2010a); however, these values are not comparable since the $C R$ ratio in Callen et al. (2010a) omits observations with negative values, whereas the 
CC_CR measure in this study does not.

Insert Table 1 about here

Panel B of Table 1 presents correlations among contemporaneous observations of the test variables, with Pearson (Spearman) correlations reported in the upper (lower) triangle of the table. The Spearman (Pearson) correlations between the bankruptcy risk metrics EDF and Campbell are 0.7789 (0.7789), both statistically significant, suggesting that they have strong convergent validity in measuring ex ante bankruptcy risk. Both of these ex ante measures are also significantly positively correlated with the ex post bankruptcy risk measure $B A N K$.

$U C_{-} P C A$ is significantly negatively associated with $C C_{-} P C A$, with a Spearman (Pearson) correlation -0.1441 (-0.0637). Except for CC_ACM, Spearman correlations among other component measures of the two types of conservatism are predominantly negative, a finding consistent with prior evidence (Beaver and Ryan (2005), Ryan (2006), Roychowdhury and Watts (2007), Ball et al. (2009)). Spearman and Pearson correlations between UC_PCA and its component unconditional conservatism metrics are uniformly positive and statistically significant, suggesting that $U C_{-} P C A$ possesses content and convergent validity. Spearman and Pearson correlations between $C_{-} C_{-} P A$ and its component conditional conservatism metrics are likewise uniformly positive and statistically significant, the only exception being its Pearson correlation with CC_ACM, which is insignificantly different from zero. These correlations suggest that CC_PCA possesses convergent validity. The Spearman and Pearson correlations among the three component measures of unconditional and conditional conservatism are within the range of $+/-0.10$ respectively. This does not mean that they lack convergent validity since they measure conservatism from different aspects. ${ }^{15}$

Pearson and Spearman correlations of unconditional conservatism with EDF and Campbell are negative, whereas the correlations of conditional conservatism with EDF and Campbell are positive. Care should be taken in interpreting these latter correlations because they are subject to omitted variable biases. In the following sections, we systematically examine the lead-lag relations between unconditional conservatism, conditional conservatism, and bankruptcy risk using multivariate analyses.

\footnotetext{
${ }^{15}$ A measure possesses convergent validity when it is positively correlated with another measure for the same concept. However, alternative measures can have a low or even negative correlation if they measure the concept from different aspects. For example, when measuring unconditional conservatism using hidden reserves (UC_RES) and an accrual-based measure (UC_ACC), UC_ACC and UC_RES could be negatively correlated; firms with higher-level reserves may have lower incentives to use accruals to increase unconditional conservatism.
} 


\subsection{Causal Relations Between Unconditional and Conditional Conservatism and Bankruptcy Risk in Full and Extremely Distressed Samples}

We first examine the lead-lag relations between unconditional and conditional conservatism using a tri-variate VARX (1) model described by equations (3) to (5), with results for the full sample and subsample of firms in extreme distress presented in Table 2, Panels A and $\mathrm{B}$, respectively. Models 1 and 2 in both Panels use $E D F_{t}$ and Campbell $t_{t}$ as bankruptcy risk measures, respectively. Panel A of Table 2 finds $U C_{-} P C A_{t-1}$ and $C C_{-} P C A_{t-1}$ to be significantly negatively associated with $E D F_{t}$ and Campbell $_{t}$, with coefficients ( $t$-statistics) of $-0.0431(-8.82)$ and $-0.0083(-15.05)$ for $E D F_{t}$, respectively, and $-0.0184(-3.65)$ and -0.0110 (-19.38) for Campbell, respectively. $F$-statistics for the null hypothesis that the predictor coefficients of $E D F_{t}$ and Campbell $_{t}$ are zero indicate rejection beyond the $99 \%$ confidence level. $E D F_{t-1}$ and Campbell $_{t-1}$ are both significantly positively associated with $U C_{-} P C A_{t}$ and negatively associated with $C C_{-} P C A_{t}$, with coefficients ( $t$-statistics) of 0.0389 (13.61) and $-0.2865(-8.01)$, respectively, for $U C_{-} P C A_{t-1}$ and $C C_{-} P C A_{t-1}$ for $E D F_{t}$, and 0.0388 (14.16) and -0.4431 (-12.95), respectively, for Campbell . These results lend support to hypotheses H1a, H1b, H2a and H2b, after controlling for endogeneity between unconditional and conditional conservatism. ${ }^{16}$ Untabulated results reveal qualitatively similar findings as those for $\mathrm{H} 1 \mathrm{a}$ and $\mathrm{H} 1 \mathrm{~b}$ above for contemporaneous associations between unconditional and conditional conservatism and bankruptcy risk. Specifically, both unconditional and conditional conservatism are negatively related to concurrent bankruptcy risk for the full sample (results available on request).

Insert Table 2 about here

For extremely distressed firms, managerial incentives and governance mechanisms may differ from those in healthier firms, which may qualitatively change relations between conservatism and bankruptcy risk for several reasons. When shareholders' implicit call options on assets are at or close to the money in deeply distressed firms, equity values will increase in asset volatility, shareholders' risk-shifting incentives may dominate and firms may have less incentive to use conservatism to mitigate bankruptcy risk. Firms' control rights also may progressively transfer to creditors, who may demand higher levels of conservatism to prevent risk shifting to creditors and wealth transferring to shareholders (Loktionov (2009)). Finally,

\footnotetext{
${ }^{16}$ In both models, conditional conservatism $C C_{-} P C A_{t-1}$ exhibits a significant positive association with subsequent unconditional conservatism $U C P C A_{t}$, with coefficients ( $t$-statistics) 0.0021 (5.17) and 0.0019 (4.67), respectively in Panel A. This result is consistent with expectation and suggests that bad news "shocks" associated with conditional conservatism generate demand for subsequent unconditional conservatism. UC_ $P C A_{t-1}$ also exhibits a positive association with subsequent conditional conservatism $C C P C A_{t}$, with coefficients ( $t$-statistics) 0.0940 (2.12) and 0.0571 (1.29), respectively. However, when we take the first difference of $U C_{-} P C A$ to consider only the unconditional conservatism that occurred in a specific fiscal year, the coefficient is significantly negative. This result is consistent with prior findings that unconditional conservatism preempts conditional conservatism (Beaver and Ryan (2005) and Ryan (2006)).
} 
the going concern assumption may no longer apply, making accrual accounting and unconditional conservatism less relevant. To investigate whether the results for the full sample hold under these conditions, we examine in Panel B of Table 5 a subsample of most distressed firms defined by the lowest decile of returns-on-assets (largest $(-R O A)$ ). Consistent with the results in Panel A, both $U C_{-} P C A_{t-1}$ and $C_{-} P C A_{t-1}$ remain significantly negatively associated with subsequent bankruptcy risk, except for $U C_{-} P C_{t-1}$ with Campbell. $E D F_{t-1}$ and Campbell $_{t-1}$ remain significantly and positively associated with $U C_{-} P C A_{\mathrm{t}}$, and CC_PCA , except for $E D F_{t-1}$ with $C_{-} P C A_{t}$. Thus, the prior findings are qualitatively similar for deeply distressed firms.

Insert Table 3 about here

To address possible concerns that our results are influenced by cross-sectional relations between unconditional conservatism, conditional conservatism and bankruptcy risk or that our results are sensitive to lag structure, we examine relations between unconditional and conditional conservatism using a tri-variate VARX (3) model described by equations (6) to (8). Results for the full sample are presented in Table 3 where Model 1 finds $U C_{-} P C A_{t-1}$, $U C_{-} P C A_{t-2}$ and $U C_{-} P C A_{t-3}$ to be consistently negatively associated with $E D F_{t}$, with the coefficient for $U C_{-} P C A_{t-1}$ statistically significant. Model 2 finds $U C_{-} P C A_{t-1}$ to be significantly negatively associated with $E D F_{t}$, and $U C_{-} P C A_{t-2}$ and $U C_{-} P C A_{t-3}$ to be positively associated with $E D F_{t}$, with the coefficient for $U C_{-} P C A_{t-2}$ statistically significant. The sums of the coefficients of $U C_{-} P C A_{t-1}, U C_{-} P C A_{t-2}$ and $U C_{-} P C A_{t-3}$ are all negative, and the $F$-statistics for the null hypothesis that the sum is zero is 72.10 and 18.48 for $E D F_{t}$ and Campbell, respectively, thus providing strong support for H1a. In both models, $\mathrm{CC}_{-} P C A_{t-1}, C C_{-} P C A_{t-2}$ and $C_{-} P C A_{t-3}$ are significantly and negatively associated with $E D F_{t}$ and Campbell $t_{t}$ and $F$ statistics for the null hypotheses that the sums of the coefficients of $C_{-} P C A_{t-1}, C C_{-} P C A_{t-2}$ and $C C_{-} P C A_{t-3}$ are zero for $E D F_{t}$ and Campbell $t_{t}$ are likewise significant beyond the $99 \%$ confidence level, thus providing strong support for $\mathrm{H} 1 \mathrm{~b}$.

In Model 1, EDF $F_{t-1}, E D F_{t-2}$ and $E D F_{t-3}$ are significantly positively associated with $U_{-} P C A_{t}$, and likewise in Model 2, Campbell $t_{t-1}$, Campbell $t_{t-2}$ and Campbell $t_{t-3}$ are consistently positively associated with $U C_{-} P C A_{t}$, but only the coefficient of Campbell $t_{t-1}$ is statistically significant. $F$-statistics for the null hypotheses that the sums of the coefficients of $E D F_{t-1}$, $E D F_{t-2}$ and $E D F_{t-3}$ and of Campbell Campbell $_{t-2}$ and Campbell Cam $_{-3}$ are zero indicate rejection at least at the $99 \%$ confidence level, thus providing strong support for $\mathrm{H} 2 \mathrm{a}$ that bankruptcy risk is positively associated with subsequent unconditional conservatism. Results for testing $\mathrm{H} 2 \mathrm{~b}$ are 
weaker. In Model $1, E D F_{t-1}$ is significantly negatively associated with $C C_{-} P C A_{t}$ and $E D F_{t-2}$ and $E D F_{t-3}$ are significantly positively associated with $C_{-} P C A_{t}$, but the sum of their coefficients is negative, and the same pattern applies to Campbell Campbell $_{t-2}$ and Campbell $t_{-3}$ in $C C_{-} P C A_{t}$ equation in Model 2. F-statistics for the null hypothesis that the sum of the coefficients of $E D F_{t-1}, E D F_{t-2}$ and $E D F_{t-3}$ is zero indicates rejection beyond the $99 \%$ confidence level in Model 1, but for the sum of the coefficients of Campbell t-1 $_{\text {, Campbell }}$ and Campbell $_{t-3}$ is insignificant, thus providing limited support for $\mathrm{H} 2 \mathrm{~b}$ that bankruptcy risk is negatively associated with subsequent unconditional conservatism.

We further compare the Akaike Information Criterion (AIC) for the corresponding VARX (1) and VARX (3) models used in Tables 2 and 3 to examine the optimal lag structure. AIC is calculated as $\mathrm{AIC}=\mathrm{N}^{*} \operatorname{Ln}((1-\mathrm{R}$-sqr $) / \mathrm{N})+2 \mathrm{~K}$, where $\mathrm{N}$ is sample size, $\mathrm{K}$ is number is independent variables, and R-sqr is the proportion of the sum of square accounted for by the model under consideration. The last two lines of Table 3 indicate that AIC numbers for VARX (1) models are consistently smaller than for VARX (3) models whereas untabulated results indicate smaller AIC numbers for VARX (1) models than for corresponding VARX (2) models. Since lower AIC numbers indicate better fit, we use VARX (1) model in subsequent empirical tests. To address the whether results are similar for each complement of $U C_{-} P C A$ and $C C_{-} P C A$, we present robustness tests for unconditional and conditional conservatism components in Appendix A and B respectively, with qualitatively consistent findings.

\subsection{Relations between Unconditional and Conditional Conservatism and Actual Bankruptcies}

Examining a subsample of firms that actually declared bankruptcy eliminates estimation error in estimating bankruptcy risk while precluding tests for the effects of bankruptcy on subsequent conservatism. For this reason, we test only hypotheses H1a and H2a for bankrupt firms using a logit model following Campbell et al. (2008), where H1a and H2a predict $\gamma<0$ :

$$
\text { BANK }_{t}=\alpha+\gamma \text { CON }_{t-1}+\text { Controls }_{t}+\mu_{t}
$$

where BANK equals one if a firm files for bankruptcy under Chapters 7 or 11 of the Bankruptcy Code, and zero otherwise, and $C O N$ refers to unconditional or conditional conservatism measured by $U C_{-} P C A$ or $C_{-} P C A$, or both. Controls $s_{t}$ include the following commonly used determinants of bankruptcy risk mainly identified in Campbell et al. (2008): the market-based profitability (NIMTAVG), the predictability of excess return relative to S\&P 500 index (EXRETAVG), R\&D investment intensity (Inten_RD), firm size relative to that of the S\&P 500 index (Rsize), the stock price (PRICE) and the risk-free rate (Rate), which are 
expected to reduce the probability of $B A N K$; the leverage ratio (Leverage), the liquidity ratio $(C a s h)$, changes in the liquidity ratio $(\triangle C a s h)$, return volatility $\left(S T D_{-} R e t\right)$ and the market-tobook equity ratio $(M B)$, which are expected to increase the probability of $B A N K$. Other controlling variables include year and industry dummies, earnings management (Emgmt) and earnings smoothing (Esmooth).

Insert Table 4 about here

Table 4 reports the estimation results. Models 1 and 3 to 5 in Table 4 find $U C_{-} P C A_{t-1}$ to be significantly negatively associated with the probability that firms file for bankruptcy, a result that holds after controlling for earnings management and earnings smoothing. However, CC_PCA $A_{t-1}$ is insignificantly associated with the probability of bankruptcy in Models 2 to 5 . These results strongly confirm hypothesis $\mathrm{H} 1 \mathrm{a}$, but do not support hypothesis $\mathrm{H} 2 \mathrm{a}$ for firms actually filing for bankruptcy. This is consistent with reduced incentives for conditional conservatism as firms enter into actual bankruptcy, perhaps because bad news is already revealed and further bad news is unhelpful for reducing information asymmetries and could even cause frictions among claimants. The signs of the control variable coefficients are consistent with expectations: NIMTAVG, Exretavg, Inten_RD, Cash and Rate are negatively associated with $B A N K$, and Leverage, STD_ret and $M B$ are positively associated with $B A N K$.

\subsection{The Cash Enhancing and Informational Roles of Accounting Conservatism and Causal Relations between Conservatism and Bankruptcy Risk}

This section examines how unconditional and conditional conservatism impact bankruptcy risk via their cash enhancing and informational roles. Table 5 replicates Table 3 , adding interactions between $U_{-} P C A, C_{-} P C A$ and $C a s h$ (Panel A) and between $U C_{-} P C A$, CC_PCA and STD_Ret $t_{t-1}$ (Panel B) to the EDF and Campbell equations. Stock volatility $S T D \_$Ret $_{t-1}$ is used to proxy for information uncertainty and information asymmetry following Zhang (2006) and Khan and Watts (2009). Panel A reveals that the interactions of both unconditional and conditional conservatism with cash (UC_PCA $A_{t-1}{ }^{*} C_{a s h}$ and CC_PCAt${ }_{1}{ }^{*} \operatorname{Cash}_{t-1}$, respectively) are significantly negatively associated with subsequent bankruptcy risk proxied by $E D F_{t}$ in Model 1, with coefficients (t-statistics) of -0.3010 (-9.46) and -0.0276 (5.83), and with subsequent bankruptcy risk proxied by Campbell in $_{t}$ Model 2, with coefficients $(t$-statistics $)-0.3437(-10.85)$ and $-0.0115(-2.44)$, respectively. $F$-statistics for the null hypothesis that the sum of the coefficients of conservatism and of its interaction with cash is zero are significant beyond the $99 \%$ confidence level for both unconditional and conditional conservatism in Models 1 and 2. This evidence in Panel A suggests that both unconditional 
and conditional conservatism mitigate bankruptcy risk via their cash enhancing roles.

Insert Table 5 about here

Panel B of Table 7 shows that the interactions of conservatism with stock return volatility $\left(U C_{-} P C A_{t-1} * S T D_{-} \operatorname{Ret}_{t-1}\right.$ and $\left.C_{-} P C A_{t-1} * S T D_{-} \operatorname{Ret}_{t-1}\right)$ are also significantly negatively associated with subsequent bankruptcy risk as proxied by $E D F_{t}$ in Model 1, with coefficients $(t$-statistics) of $-0.0453(-3.00)$ and $-0.0201(-10.56)$, respectively. Similarly, the interaction of unconditional conservatism with return volatility is also significantly negative for Campbell $_{t}$ in Model 2, with a coefficient ( $t$-statistic) of -0.1367 (-9.07), but the interaction of conditional conservatism with return volatility is statistically insignificant. $F$-statistics for the null hypothesis that the sums of coefficients for conservatism's interactions with return volatility are zero are nonetheless significant beyond the $90 \%$ confidence level for both unconditional and conditional conservatism in Models 1 and 2. Overall, this evidence in Panel B suggests that both unconditional and conditional conservatism help mitigate bankruptcy risk via their informational roles.

\subsection{Sarbanes-Oxley, Auditor Turnover and Causal Relations between Bankruptcy Risk and Subsequent Unconditional and Conditional Conservatism}

This section uses the passage of the Sarbanes-Oxley Act in 2002 (SOX) and auditor resignations as natural experiments to examine the effects of auditors, regulators and litigation on causal relations between bankruptcy risk and unconditional and conditional conservatism. Prior evidence suggests that SOX heightened legal and regulatory attention to financial reporting and increased managerial legal exposures and punishment, and thus increased accounting conservatism (Lobo and Zhou (2006), Cefaratti et al. (2010)). ${ }^{17}$ Auditor resignations are often triggered by aggressive reporting or misrepresentations (Krishnan and Krishnan (1997), Menon and William (2008), Krishnan et al. (2010)) that heighten litigation risk and monitoring by successor auditors, regulators and investors. Our main argument for relations between bankruptcy risk and subsequent unconditional and conditional conservatism is that monitoring by auditors and regulators mainly enhances unconditional conservatism which is their primary focus (Qiang (2007)) and the relation is stronger as bankruptcy risk increases. If this argument is valid, then the interaction of bankruptcy risk and an indicator for the post-SOX period (SOX), and the interaction of bankruptcy risk and an indicator for post-

\footnotetext{
${ }^{17}$ Lobo and Zhou (2006) find that both unconditional conservatism (measured by total accruals) and conditional conservatism (Basu (1997) measure) increased in the post-SOX period. Similarly, Cefaratti et al. (2010) report that the passage of SOX enhanced litigation risk and increased conservatism. We find that unconditional conservatism (UCPCA) increases from 0.3443 in the pre-SOX period (2000-2002) to 0.3805 in the post-SOX period (2003-2005), with a $t$-statistic of 8.77 . Conditional conservatism (CC_PCA) increases from 0.8055 in the pre-SOX period to 0.8582 in the post-SOX period, with a $t$ statistic of 1.60 .
} 
auditor-resignation periods (Post_resign) should increase subsequent unconditional conservatism. We test this conjecture by replicating the analysis in Panel A, Table 2, adding these interactions.

Results reported in Panel A of Table 6 reveal that interactions of $S O X$ with $E D F_{t-1}$ and Campbell $_{t-1}$ are both statistically positive for $U C_{-} P C A_{t}$, suggesting that enhanced auditor and regulator monitoring following the passage of $S O X$ enhanced the effects of bankruptcy risk on subsequent unconditional conservatism as predicted by $\mathrm{H} 2 \mathrm{a}$. In contrast, interactions of $S O X$ with $E D F_{t-1}$ and Campbell $t_{t-1}$ are insignificantly associated with $C_{-} P C A_{t}$, suggesting that $S O X$ influenced little the effects of bankruptcy risk on subsequent conditional conservatism as predicted by $\mathrm{H} 2 \mathrm{~b}$. The interaction of $S O X$ with $U C_{-} P C A_{t-1}$ is statistically significant for $E D F_{t}$ but is insignificant for Campbell, with the opposite is true for the interaction of SOX with CC_PCA $A_{t-1}$. These findings suggest that SOX enhanced, albeit modestly, the mitigating effects of both unconditional and conditional conservatism on subsequent bankruptcy risk.

\section{Insert Table 6 about here}

For a subsample of 124 firms with auditor resignations between 2000 and $2007,{ }^{18}$ panel B of Table 6 reveals that interactions of Post_resign with $E D F_{t-1}$ and Campbell t-1 $_{\text {are statistically }}$ significant for $U C_{-} P C A_{t}$ but insignificant for $C_{-} P C A_{t}$ in both Models 1 and 2. Interactions of Post_resign with $U C_{-} P C A_{t-1}$ and with $C_{-} P C A_{t-1}$ are insignificant for both $E D F_{t}$ and Campbell $t_{t}$ in both Models 1 and 2, respectively. Untabulated results indicate that mean UC_PCA (CC_PCA) in the pre-resignation period is 0.3710 (1.2295), which increases (decreases) to 0.4200 (1.1639) in the post-resignation period, with $t$-statistics for these changes significant for $U C_{-} P C A$ and insignificant for $C_{-} P C A$. Overall, Table 6 provides evidence suggesting that SOX and auditor resignations increase unconditional conservatism more than conditional conservatism as bankruptcy risk increases, contributing to a positive relation between bankruptcy risk and subsequent unconditional conservatism as predicted by hypothesis $\mathrm{H} 2 \mathrm{a}$.

\subsection{Conservatism Gaming and Causal Relations between Conservatism and Bankruptcy Risk}

"Conservatism gaming," a version of earnings smoothing whereby managers apply more conservatism during good times to provide earnings cushions during downturns is a possible alternative explanation for observed relations between conservatism and bankruptcy risk, with a negative relation between conservatism gaming and bankruptcy risk follows from earnings

\footnotetext{
${ }^{18}$ Auditor resignation data were collected from AuditAnalytics in the WRDS database, 6 in fiscal year 2000, 4 in 2001, 6 in 2002, 18 in 2003, 33 in 2004, 22 in 2005, 23 in 2006 and 12 in 2007.
} 
smoothing studies. Smith and Stulz (1985) argue that earnings smoothing may serve as a hedge against bankruptcy risk; Trueman and Titman (1988) concur that earnings smoothing may lower claimholders' perceptions of bankruptcy risk by lowering perceptions of earnings volatility. To address whether causal relations between unconditional and conditional conservatism and bankruptcy risk are robust to conservatism gaming, we employ a tetra-variate VARX (1) model consisting of equations (11) to (14):

$B R_{t}=\alpha_{10}+\beta_{11} B R_{t-1}+\gamma_{11} U C_{-} P C A_{t-1}+\delta_{11} C_{-} P C A_{t-1}+\theta_{11}$ Esmooth $_{t-1}+$ Controls $_{t}+\varepsilon_{11}$

$U C_{-} P C A_{t}=\alpha_{20}+\beta_{21} B R_{t-1}+\gamma_{21} U C_{-} P C A_{t-1}+\delta_{21} C C_{-} P C A_{t-1}+\theta_{21}$ Esmooth $_{t-1}+$ Controls $_{t}+\varepsilon_{21}$

CC_PCA $A_{t}=\alpha_{30}+\beta_{31} B R_{t-1}+\gamma_{31} U C_{-} P C A_{t-1}+\delta_{31} C C_{-} P C A_{t-1}+\theta_{31}$ Esmooth $_{t-1}+$ Controls $_{t}+\varepsilon_{31}$

Esmooth $_{t}=\alpha_{40}+\beta_{41} B R_{t-1}+\gamma_{41} U C_{-} P C A_{t-1}+\delta_{41} C_{-} P C A_{t-1}+\theta_{41}$ Esmooth $_{t-1}+$ Controls $_{t}+\varepsilon_{41}$

where $B R$ is $E D F$ or Campbell and Controls in $_{t}$ equations (10) to (12) and their predictions are the same as for equations (3) to (5) and Controls $s_{t}$ in equation (14) include Leverage $e_{t} R O A_{t}$, $\operatorname{Ln}(M V)_{t}$, Volatility_ROA , and industry and year dummies, which are previously identified determinants of earnings smoothing. We consider two types of income smoothing to proxy for conservatism gaming: innate smoothing, the product of negative one times the Spearman correlation between accruals and OCF, and discretionary smoothing, the decile ranking of the product of negative one times the ratio of the standard deviation of accruals to that of OCF.

\section{Insert Table 7 about here}

Table 7 reveals that the causal relations between the two types of conservatism and bankruptcy risk observed above are robust to conservatism gaming. Qualitatively similar results hold for discretionary smoothing (results not tabulated). Table 7 further reveals that innate smoothing, $E_{s m o o t h}{ }_{t-1}$, is significantly negatively associated with Campbell, consistent with theoretical predictions (Smith and Stulz (1985) and Trueman and Titman (1988)) and prior findings that innate smoothing reveals information and increases firm value (Tucker and Zarowin (2006), Leuz et al. (2003)). In contrast, discretionary smoothing has a weak mitigating effect on bankruptcy risk, whereas bankruptcy risk is negatively associated subsequent discretionary smoothing, consistent with the argument that discretionary smoothing reduces information transparency (untabulated results available on request).

\subsection{Robustness Checks}

\section{Sensitivity Tests for Validity of the VARX Models}

Because VARX models are sensitive to order, we reordered predictors in each equation with qualitatively similar findings. First-differenced specifications for the VARX models yield weaker but qualitatively similar findings, with autoregressive coefficients for the two 
conservatism measures significantly negative, consistent with the inference from our DickeyFuller unit-root tests that taking first-differences may yield biased results in the VARX models with no unit-root. Concerns that mean-reversions of accruals or EDF $F_{t}$ and Campbell $_{t}$ could explain our findings is made unlikely by our design that utilizes three-year averages for $U C_{-} A C C$ and $C C_{-} A C M$ to control for mean-reversions and conservatism metrics that are relatively insensitive to accrual reversals $\left(U C_{-} B M, U N C_{-} R E S, C C_{-} A R\right.$ and $\left.C C_{-} C R\right)$. In all $E D F_{t}$ and Campbell $_{t}$ regressions, the coefficients on $E D F_{t-1}$ and on Campbell Car $_{\text {a }}$ are significantly positive, indicating no mean-reverting tendencies in the bankruptcy risk measures.

\section{Alternative Tests for Cash Enhancing and Informational Roles of Conservatism}

To address the possibility that firms with weak (strong) cash flows prefer aggressive (conservative) reporting with cash holdings thus causing higher conservatism and lower bankruptcy risk, we orthogonalize both $U C_{-} P C A$ and $C C_{-} P C A$ by the lagged value of cash, and use the residual value of $U C_{-} P C A$ and $C_{-} P C A$ to replace their original values in the VARX (1) models in Panel A, Table 5. This treatment does not qualitatively change our results. Using the upside potentials of cash holdings to proxy for cash following BMS (2011), the results in Panel A, Table 5 do not qualitatively change. For Panel B, Table 5, we alternatively use earnings forecast errors and earnings forecast dispersions (Zhang (2006)), and the information asymmetry component of PIN score adjPIN (Duarte and Young (2009)) to measure information uncertainty and asymmetry, and these yield qualitatively similar findings.

\section{Controls for Debt Contracting, Debtholders' and Shareholders' Interests}

Whereas results in Panel B of Table 3 suggest that relations between conservatism and bankruptcy risk hold for bankrupt firms, there remains the question of whether the observed relations are robust to controls for debt contracting, debtholders' and shareholders' interests. To address this question, we replicate the tests in Panel A of Table 3 introducing additional controls for private debtholder monitoring, leverage, auditor going-concern opinions and credit ratings. Private debtholder monitoring is measured as the ratio of the sum of private long-term debt, other long-term debt and capitalized lease obligations to total long-term debt, following Qiang (2007). Leverage is an indicator of higher debt costs, larger debtholder claims, more intense monitoring and accentuated conflicts of interests between shareholders and debtholders. A dummy for periods following auditors' going-concern opinions proxies for enhanced debtholders control relative to shareholders. Untabulated results reveal that these additional controls do not qualitatively change our findings (available on request).

Debt ratings proxy for both cost of debt and monitoring by rating agencies. We code 
S\&P long-term debt-ratings on a scale of 1 to 21 , with 1 for a "AAA" rating and "21" for "D" rating. Untabulated results show that results previously reported remain qualitatively unchanged after controlling for credit ratings. Surprisingly, credit ratings are significantly negatively associated with $E D F_{t}$ and Campbell. They are positively associated with $U C_{-} P C A_{t}$ and $C_{-} P C A_{t}$, consistent with both the monitoring role of credit ratings, and with credit ratings inadequately capturing default risk, as illustrated by the bankruptcies of highly-rated firms during the 2008-2009 financial crisis.

\section{Controls for Earnings Management}

To examine whether our results are robust to earnings management, we rerun the tetravariate VARX (1) model consisting of equations (10) to (13) by replacing Esmooth with Emgmt,. Untabulated results show that the conclusions about the causal relations between bankruptcy risk and unconditional and conditional conservatism still hold. Importantly, both $U C_{-} P C_{t-1}$ and $C_{-} P C A_{t-1}$ are negatively associated with subsequent Emgmt, corroborating Watts' (2003) and Kothari et al.'s (2010) reasoning that, absent conservatism, financial reporting would be biased upward a priori in practice (results are available on request).

\section{Alternative Measures of Unconditional and Conditional Conservatism and Bankruptcy Risk}

To address the possibility that $U C_{-} A C C$ and $U C_{-} R E S$ insufficiently reflect discretionary unconditional conservatism, we alternatively use Qiang's (2007) accrual-based measure to

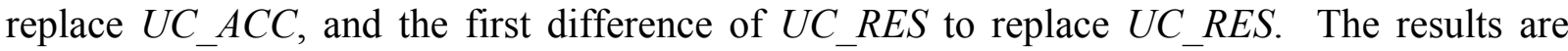
qualitatively similar to previous findings. To address the possibility that the industry-adjusted $\mathrm{BM}$ ratio $U C_{-} B M$ captures both unconditional and conditional conservatism, we use the industry-specific component of the BM ratio to proxy for unconditional conservatism following Qiang (2007) and Beaver and Ryan (2000) to find that results are qualitatively unchanged. We do not use this measure in our main tests because it is invariant over time and thus inapplicable to VARX time-series modeling.

To address the possibility that $\mathrm{CC}_{-} \mathrm{AR}$ is subject to a potential mechanical relationship with EDF and Campbell since all are functions of leverage, return volatility, size and book-tomarket ratios, we use the negative skewness measure in Zhang (2008) to replace $C C_{-} A R$. Results for the tests in Panel A of Table 2 are qualitatively unchanged, suggesting that this potential mechanical relationship is not a serious concern. Using an $A \_s c o r e$ defined as the ratio of the $\mathrm{C}$ score to the sum of $\mathrm{C}$ score and G score from Khan and Watts (2009) and CC_CR calculated using the direct method following Callen et al. (2009) to measure conditional conservatism also do not qualitatively change our findings. Using averages and 
rankings of $U C_{-} A C C, U C_{-} B M$ and $U N C O N_{-} R E S$ to measure unconditional conservatism, and of $C_{-} A C M, C C_{-} A R$ and $C C_{-} C R$ to measure conditional conservatism yield qualitatively similar results. When Altman's (1968) Z-score is used as an alternate bankruptcy risk metric, main results in Tables 2 and 3 are qualitatively unchanged. Following Campbell et al. (2009) we winsorise stock prices below $\$ 15$ to avoid estimation bias caused by small-cap stocks; when we relax this limitation, our results do not qualitatively change (all results available on request).

\section{Conclusion}

This study examines relations between accounting conservatism and bankruptcy risk that follow from conservatism's cash enhancing and informational properties. Our primary findings are negative associations between both unconditional and conditional conservatism and subsequent bankruptcy risk consistent with conservatism's cash enhancing and informational roles, a positive (negative) association between bankruptcy risk and subsequent unconditional conservatism consistent with the interests of auditors, investors and regulators to mitigate future failure risk, and a negative association between bankruptcy risk and subsequent and concurrent conditional conservatism, consistent with countervailing managerial incentives to withhold bad news for career motives. Further analyses provide confirming evidence that both the cash enhancing and informational roles of conservatism help mitigate bankruptcy, and that regulators' and auditors' monitoring enhances the demand for unconditional conservatism as bankruptcy risk increases, with similar effects for SOX regulations and auditor resignations. The findings are qualitatively unchanged under conditions of extreme distress and actual bankruptcy, and are robust to endogeneity between unconditional and conditional conservatism, debt contracting considerations, conservatism gaming and other controls.

These findings have several key implications. First, they provide evidence consistent with a traditional rationale for accounting conservatism that it arose from the requests of capital providers, joined in recent times by auditors and regulators, to help conserve cash and enhance transparency, and thereby reduce failure risk. Second, our evidence that accounting conservatism mitigates bankruptcy risk is consistent with the findings that conservatism reduces cost of capital and increases trading contracting efficiency (Zhang (2008), Hui et al. (2009b)) but makes contributions by showing that the evidence follows from the cash enhancing and informational roles of conservatism. Third, this evidence is not only central to the interests of firms' stakeholders but also to economic policy makers by helping to dampen 
the contagion effects of bankruptcy. ${ }^{19}$ Fourth, findings that bankruptcy risk is related differently with subsequent unconditional and conditional conservatism are consistent with offsetting managerial, auditors' and regulators' interests. Lastly, our evidence helps inform ongoing debates regarding the role of conservatism as an enduring core concept of financial accounting.

As this is the first study to empirically examine relations between accounting conservatism and bankruptcy risk, there is considerable potential for related research. For example, this study leaves largely unexplored specific linkages between conservatism and bankruptcy risk that explain precisely how its cash enhancing and informational properties relate to bankruptcy risk, how bankruptcy risk influences decisions regarding unconditional and conditional conservatism, how these relations are affected by differing economic conditions, how they relate to economic policies, and whether they hold in other countries with different institutional arrangements, for example, in developing economies and settings with differing bankruptcy provisions or regulations.

\footnotetext{
${ }^{19}$ Thus, this study complements evidence in Francis et al. (2010) that conservatism benefited shareholders during the 20082009 financial crisis and in Kim and Zhang (2010) that conservatism helps mitigate stock market crash risk, suggesting that conservatism is relevant to economic policy-making.
} 


\section{References}

Ahmed, A. S., Billings, B. K., Morton, R. M. and Stanford-Harris, M., 2002. The Role of Accounting Conservatism in Mitigating Bondholder-Shareholder Conflicts over Dividend Policy and in Reducing Debt Costs. The Accounting Review 77, 867-890.

Ahmed, A. S. and Duellman, S., 2007. Accounting Conservatism and Board of Director Characteristics: An Empirical Analysis. Journal of Accounting and Economics 43, 411-437.

Altman, E., 1968. Financial Ratios, Discriminant Analysis and the Prediction of Corporate Bankruptcy. Journal of Finance 23, 589-609.

Anderson, R. and Sundaresan, S., 1996. Design and Valuation of Debt Contracts. Review of Financial Studies 9, 37-68.

Ball, R., Kothari, S. P. and Nikolaev, V., 2009. Econometrics of the Basu Asymmetric Timeliness Coefficient and the Accounting Conservatism. Working paper, University of Chicago.

Barth, M. E., Landsman, W. R. and Lang, M. H., 2008. International Accounting Standards and Accounting Quality. Journal of Accounting Research 46, 467-498.

Basu, S., 1997. The Conservatism Principle and the Asymmetric Timeliness of Earnings. Journal of Accounting and Economics 24, 3-37.

Basu, S., 2009. Conservatism Research: Historical Development and Future Prospects. Chinese Journal of Accounting Research 2, 1-20.

Beaver, W. H. and Ryan, S. G., 2000. Biases and Lags in Book Value and Their Effects on the Ability of the Book-To-Market Ratio to Predict Book Return on Equity. Journal of Accounting Research 38, 127-148.

Beaver, W. H. and Ryan, S. G., 2005. Unconditional and conditional Conservatism: Concepts and Modeling. Review of Accounting Studies 10, 269-309.

Biddle, G. C., 1980. Accounting Methods and Management Decisions: The Case of Inventory Costing and Inventory Policy. Journal of Accounting Research 18, 235-280.

Biddle, G. C., Ma, M. and Song, M., 2011. The Risk Management Role of Accounting Conservatism. Working paper, University of Hong Kong.

Black, F. and Scholes, M., 1973. The Pricing of Options and Corporate Liabilities. Journal of Political Economy 81, 637-654.

Bublitz, B. and Ettredge, M., 1989. The Information in Discretionary Outlays: Advertising, Research and Development. The Accounting Review 64, 108-124.

Bushman, R., M., Piotroski, J. D. and Smith, A., 2010. Capital Allocation and Timely Accounting Recognition of Economic Losses. Working Paper, The University of North Carolina at Chapel Hill.

Callen, J. L., Segal D. and Hope, O-K., 2010a. The Pricing of Conservative Accounting and the Measurement of Conservatism at the Firm-Year Level. Review of Accounting Studies 15, 145-178.

Callen, J. L., Chen, F., Dou, Y. and Xin, B., 2010b. Information Asymmetry and the Debt Contracting Demand for Accounting Conservatism. Working paper, University of Toronto. 
Campbell, J., Hilscher, J. and Szilagyi, J., 2008. In Search of Distress Risk. Journal of Finance 53, 2899-2939.

Carapeto, M., 2005. Bankruptcy Bargaining with Outside Options and Strategic Delay. Journal of Corporate Finance 11, 736-746.

Cefaratti, M., Dorminey, J., Lin, H., and Reed, T., 2010. The Effect of Litigation Risk on Conservatism: A Comparative Study of PSLRA and SOX. Working paper, Northern Illinois University.

Chen, N., 2003. Three Essays on Information Asymmetry and Corporate Defaults. Columbia University.

De Ste. Croix, G. E. M., 1956. Greek and Roman Accounting, pp. 14-74. In: Littleton, A. C. and Yamey, B. S., ed., Studies in the History of Accounting, Richard D. Irwin, Homewood, IL.

Doan, T., 1992. Rats User's Manual, Version 4.0, Estima.

Duarte, J. and Young, L. 2009. Why is PIN priced? Journal of Financial Economics 91, 119138.

Eberhart, A., Maxwell, W. and Siddique, A., 2008. A Reexamination of the Tradeoff between the Future Benefit and Riskiness of R\&D Increases. Journal of Accounting Research 46, 27 52.

Fama E. F. and French, K. R., 1997. Industry Costs of Equity. Journal of Financial Economics 43, 153-192.

Financial Accounting Standards Board, 1980. Statement of Financial Accounting Concepts No. 2, Qualitative Characteristics of Accounting Information.

Financial Accounting Standards Board, 2008. Conceptual Framework for Financial Reporting: The Objective of Financial Reporting and Qualitative Characteristics and Constraints of Decision-Useful Financial Reporting Information. Exposure Draft. Financial Accounting Series No. 1570-100.

Financial Accounting Standards Board, 2010. Statement of Financial Accounting Concepts No. 8. Conceptual Framework for Financial Reporting.

Francis, B., Hasan, I. and Wu, Q., 2010. The Benefits of Accounting Conservatism to Shareholders: Evidence from the Financial Crisis. Working paper, Rochester Institute of Technology.

Francis, J. and Martin, X., 2010. Acquisition Profitability and Timely Loss Recognition. Journal of Accounting and Economics 49, 161-178.

Giammarino, Ronald M., 1989. The Resolution of Financial Distress. Review of Financial Studies, 2, 25-47.

Givoly, D. and Hayn, C., 2000. The Changing Time-Series Properties Of Earnings, Cash Flows and Accruals: Has Financial Reporting Become More Conservative? Journal of Accounting and Economics 29, 287-320.

Givoly, D., Hayn, C. and Natarajan, A., 2007. Measuring Reporting Conservatism. The Accounting Review 82, 65-106.

Gox, R. and Wagenhofer, R., 2009. Optimal Impairment Rules. Journal of Accounting and Economics 48, 2-16.

Granger, C. W. J., 1969. Investigating Causal Relations by Econometric Models and Crossspectral Methods. Econometrica 37 , 424-438. 
Guay, W. and Verrecchia, R. E., 2007. Conservative Disclosure. Working paper, University of Pennsylvania.

Hagerman, R. and Zmijewski, M. E., 1979. Some Economic Determinants of Accounting Policy Choice. Journal of Accounting and Economics 1, 141-61.

Hertzel, M. G., Officer, M. S., Li, Z. and Rodgers, K. J., 2008. Inter-Firm Linkages and the Wealth Effects of Financial Distress Along the Supply Chain. Journal of Financial Economics 87, 374-387.

Hillegeist, Keating, E. K., Cram, D. P. and Lundstedt, K. G., 2004. Assessing the Probability of Bankruptcy. Review of Accounting Studies 9, 5-34.

Hui, K. W., Morse, D. and Matsunaga, S., 2009a. The Impact of Conservatism on Management Quantitative Earnings Forecasts. Journal of Accounting and Economics 47, 192207.

Hui, K. W, Klasa, S. and Yeung, E., 2009b. Corporate Suppliers and Customers and Accounting Conservatism. Working paper, Hong Kong University of Science and Technology. Jones, S., 2011. Does the Capitalization of Intangible Assets Increase the Predictability of Corporate Failure?

Jorion, P. and Zhang, G., 2009. Credit Contagion from Counterparty Risk. Journal of Finance 64, 2053-2087.

Khan, M. and Watts, R., 2009. Estimation and Empirical Properties of a Firm-Year Measure of Conservatism. Journal of Accounting and Economics 48, 132-150.

Kim, J., Ramaswamy, K. and Sundaresan, S., 1993. Does Default Risk in Coupons Affect the Valuation of Corporate Bonds: A Contingent Claims Model. Financial Management, 117131.

Kim, J. and Zhang, L., 2010. Does Accounting Conservatism Reduce Stock Price Crash Risk? Firm-Level Evidence. Working paper, City University of Hong Kong.

Kirschenheiter, M. and Ramakrishnan, R., 2010. Prudence Demands Conservatism. Working paper, University of Illinois at Chicago.

Kothari, S. P., Shu, S. and Wysocki, P., 2009. Do Managers Withhold Bad News? Journal of Accounting Research 47, 241-276.

Kothari, S. P., Ramanna, K. and Skinner, D. J., 2010. Implications for GAAP from an Analysis of Positive Research in Accounting. Journal of Accounting and Economics 50, 246248.

Krishnan, J., and Krishnan, J., 1997. Litigation Risk and Auditor Resignations. The Accounting Review 72 539-60.

Krishnan, G., Sun, L. and Wang, Q., 2010. Accruals Quality, Audit Fees, and Auditor Resignations. Working paper, Lehigh University.

LaFond, R. and Watts, R., 2008. The Information Role of Conservatism. The Accounting Review 83, 447-478.

Lang, L. and Stulz, R., 1992. Contagion and Competitive Intra-industry Effects of Bankruptcy Announcements. Journal of Financial Economics 32, 45-60.

Lara, J. M. G., Osma, B. G. and Penalva, F., 2009. Accounting Conservatism and Corporate Governance. Review of Accounting Studies 14, 161-201. 
Lara, J. M. G., Osma, B. G. and Penalva, F., 2010a. Conditional Conservatism and Cost of Capital. Review of Accounting Studies, forthcoming.

Lara, J. M. G., Osma, B, G. and Penalva, F., 2010b. Conditional Conservatism and Firm Investment Efficiency. Working paper, Universidad Carlos III De Madrid.

Leuz, C., Nanda, D. and Wysocki, P., 2003. Earnings Management and Investor Protection: An International Comparison. Journal of Financial Economics 69, 505-527.

Lev, B., Sarath, B. and Sougiannis, T., 2005. R\&D Reporting Biases and Their Consequences. Contemporary Accounting Research 22, 977-1026.

Li, J., 2008. Accounting Conservatism, Information Uncertainty and Analysts' Forecasts. Working paper, Carnegie Mellon University.

Li, X., 2010. Accounting Conservatism and the Cost of Capital: International Analysis. Working paper, London Business School.

Lobo, G. J. and Zhou, J., 2006. Did Conservatism in Financial Reporting Increase After the Sarbanes-Oxley Act? Initial Evidence. Accounting Horizons 20, 57-73.

Loktionov, Y., 2009. Does Accounting Quality Mitigate Risk Shifting? Working paper, Massachusetts Institute of Technology.

Louis, H., Sun, A. and Urcan, O., 2009. Value of Cash Holdings and Accounting Conservatism. Working paper, Pennsylvania State University.

Menon, K. and Williams, D., 2008. Management Turnover Following Auditor Resignations. Contemporary Accounting Research 25, 567-604.

Merton, R. C., 1974. On The Pricing of Corporate Debt: The Risk Structure of Interest Rates. Journal of Finance 29, 449-470.

Mooradian, R. M., 1994. The Effect of Bankruptcy Protection on Investment: Chapter 11 as a Screening Device. Journal of Finance, 49, 1403-1430.

Ohlson, J. A., 1980. Financial Ratios and the Probabilistic Prediction of Bankruptcy. Journal of Accounting Research 18, 109-131.

Parker S., Peters G. and Turetsky, H., 2002. Corporate Governance and Corporate Failure: A Survival Analysis. Corporate Governance 2, 4-12.

Penman, S. H. and Zhang, X., 2002. Accounting Conservatism, the Quality of Earnings, and Stock Returns. The Accounting Review 77, 237-264.

Qiang, X., 2007. The Effects of Contracting, Litigation, Regulation, and Tax Costs on Unconditional and Conditional Conservatism: Cross-Sectional Evidence at the Firm Level. The Accounting Review 82, 759-796.

Qiang, X., 2008. The Information Role of Unconditional and Conditional Conservatism. Working paper, Xiamen University.

Roychowdhury, S. and Watts, R. L., 2007. Asymmetric Timeliness of Earnings, Market-ToBook and Conservatism in Financial Reporting. Journal of Accounting and Economics 44, 2 31.

Ryan, S. G., 2006. Identifying Conditional Conservatism. European Accounting Review 15, $511-525$.

Shumway, T., 2001. Forecasting Bankruptcy More Accurately: A Simple Hazard Model. Journal of Business 74, 101-124. 
Sims, C. A., 1980. Macroeconomics and Reality. Econometrica 48, 1-49.

Smith, C. W. and Stulz, R. M., 1985. The Determinants of Firms' Hedging Policies. Journal of Financial and Quantitative Analysis 20, 391-405.

Srivastava, A. and Tse, S., 2010. The Contribution of Delayed Gain Recognition to Trends in Conservatism: A Re-Examination Using a New Approach to Measuring Accounting Conservatism. Working paper, Northwestern University.

Trueman, B. and Titman, S., 1988. An Explanation for Accounting Income Smoothing. Journal of Accounting Research 26, 127-139.

Tucker J. W. and Zarowin, P. A., 2006. Does Income Smoothing Improve Earnings Informativeness? The Accounting Review 81, 251-270.

Uhrig-Homburg, M., 2005. Cash-flow Shortage as an Endogenous Bankruptcy Reason. Journal of Banking and Finance 29, 1509-1534.

Vassalou, M. and Xing, H., 2004. Default Risk in Equity Returns. Journal of Finance 59, 831-868.

Vuolteenaho, T., 2002. What Drives Firm-Level Stock Returns? Journal of Finance 57, 233 264.

Watts, R., 2003. Conservatism in Accounting Part I: Explanations and Implications. Accounting Horizons 17, 207-221.

Wittenberg-Moerman, R., 2008. The Role of Information Asymmetry and Financial Reporting Quality in Debt Trading: Evidence from the Secondary Loan Market. Journal of Accounting and Economics 46, 240-260.

Zmijewski, M. E., 1984. Methodological Issues Related to the Estimation of Financial Distress Prediction Models. Journal of Accounting Research 22, 59-82.

Zhang, F., 2006. Information Uncertainty and Stock Returns. Journal of Finance 61, 105-137.

Zhang, J., 2008. The Contracting Benefits of Accounting Conservatism to Lenders and Borrowers. Journal of Accounting and Economics 45, 27-54. 


\section{Table 1 Descriptive Statistics for Test Variables}

This table reports the descriptive statistics for the full sample of firm-year observations from 1989 through 2007. Panel A presents the summary statistics and Panel B presents pairwise correlations among bankruptcy risk and accounting conservatism measures. The upper (lower) triangle of Panel B displays Pearson product-moment (Spearman) correlations with highlighted figures indicating statistical significance at the $90 \%$ confidence level. Variable definitions are provided below.

\begin{tabular}{|c|c|c|c|c|}
\hline \multicolumn{5}{|c|}{ Panel A: Summary Statistics for the Full Sample } \\
\hline Variable & Mean & Q1 & Median & Q3 \\
\hline EDF (unranked, \%) & 3.6502 & 0.0000 & 0.0000 & 0.0558 \\
\hline Campbell (unranked, \%) & 0.0127 & 0.0014 & 0.0028 & 0.0064 \\
\hline$B A N K$ & 0.0059 & 0.0000 & 0.0000 & 0.0000 \\
\hline$U C \_P C A$ & 0.3659 & 0.1897 & 0.3639 & 0.5319 \\
\hline$U C \_A C C$ & -0.0012 & -0.0218 & 0.0010 & 0.0209 \\
\hline$U C_{-} B M$ (unranked) & -1.9489 & -2.2175 & -1.3437 & -0.8280 \\
\hline$U C_{-} R E S$ & 0.0729 & 0.0000 & 0.0190 & 0.0910 \\
\hline$C C_{-} P C A$ & 0.9188 & 0.4394 & 0.9534 & 1.5941 \\
\hline$C C_{-} A C M$ & 0.0189 & 0.0004 & 0.0156 & 0.0355 \\
\hline$C C_{-} A R$ & 2.1255 & 1.2598 & 1.9177 & 2.8431 \\
\hline$C C_{-} C R$ & -0.3102 & -0.4259 & -0.1237 & 0.1165 \\
\hline Leverage & 5.8566 & 4.3320 & 5.8492 & 7.3159 \\
\hline $\ln (M V)$ & 0.2540 & 0.1290 & 0.2478 & 0.3622 \\
\hline$R O A$ & 0.0336 & 0.0141 & 0.0420 & 0.0728 \\
\hline STD_Ret & 0.4833 & 0.2939 & 0.4226 & 0.6119 \\
\hline Cash & 0.0868 & 0.0131 & 0.0417 & 0.1156 \\
\hline$\triangle$ Cash & 0.0061 & -0.0103 & 0.0015 & 0.0217 \\
\hline Rate & 0.0418 & 0.0287 & 0.0460 & 0.0516 \\
\hline Inten_RD & 0.1261 & 0.0054 & 0.0219 & 0.0612 \\
\hline Monitor & 0.8448 & 1.0000 & 0.8924 & 1.0000 \\
\hline Rating & 9.0508 & 9.0000 & 70000 & 12.0000 \\
\hline Esmooth (unranked) & 0.6048 & 0.4000 & 0.7000 & 0.9000 \\
\hline Emgmt & -0.2631 & -0.4550 & -0.2735 & -0.0771 \\
\hline Volatility_ROA & 0.0054 & 0.0002 & 0.0006 & 0.0023 \\
\hline Turn & 1.1700 & 0.6405 & 1.0352 & 1.4803 \\
\hline Eissue & 0.0530 & 0.0000 & 0.0000 & 0.0050 \\
\hline Dissue & 0.2137 & -0.0457 & 0.0566 & 0.2225 \\
\hline Growth & 0.2649 & 0.0051 & 0.0858 & 0.1955 \\
\hline Nimtaavg & 0.0305 & 0.0101 & 0.0311 & 0.0476 \\
\hline Exretavg & -0.0031 & -0.0244 & 0.0002 & 0.0226 \\
\hline Rsize & -10.0948 & -11.5031 & -10.0096 & -8.6159 \\
\hline$M b$ & 0.9042 & 0.4510 & 0.7442 & 1.2077 \\
\hline Price & 2.3341 & 2.1401 & 2.7081 & 2.7081 \\
\hline
\end{tabular}


Table 1 Descriptive Statistics for Test Variables (Cont'd)

Panel B: Correlation Matrix for the Full Sample

\begin{tabular}{|c|c|c|c|c|c|c|c|c|c|c|c|}
\hline Variable & 1. & 2. & 3. & 4. & 5. & 6. & 7. & 8. & 9. & 10. & 11. \\
\hline 1. $E D F$ & 1 & 0.7789 & 0.0265 & -0.1948 & -0.0333 & -0.2300 & -0.0138 & 0.2404 & -0.0023 & 0.4880 & 0.0671 \\
\hline 2. Campbell & 0.7789 & 1 & 0.0348 & -0.0590 & 0.0334 & -0.2136 & -0.0025 & 0.2468 & -0.0081 & 0.4764 & 0.0788 \\
\hline 3. $B A N K$ & 0.0265 & 0.0348 & 1 & -0.0287 & -0.0222 & -0.0256 & -0.0096 & 0.0117 & -0.0103 & 0.0407 & -0.0035 \\
\hline 4. $U C_{-} P C A$ & -0.2168 & -0.2170 & -0.0298 & 1 & 0.1820 & 0.9025 & 0.4861 & -0.0637 & 0.1237 & -0.2020 & 0.0104 \\
\hline 5. $U C \_A C C$ & -0.0274 & 0.0397 & -0.0158 & 0.1611 & 1 & 0.0517 & 0.0489 & 0.0029 & 0.4819 & -0.0728 & 0.0284 \\
\hline 6. $U C_{-} B M$ & -0.2303 & -0.2139 & -0.0256 & 0.9349 & 0.0574 & 1 & 0.0808 & -0.0964 & 0.0516 & -0.2485 & -0.0061 \\
\hline 7. UC_RES & -0.0474 & -0.1398 & -0.0078 & 0.3023 & -0.0390 & 0.0411 & 1 & 0.0468 & 0.0551 & 0.0514 & 0.0301 \\
\hline 8. $C C_{-} P C A$ & 0.4111 & 0.4095 & 0.0317 & -0.1441 & -0.0243 & -0.1704 & -0.0028 & 1 & -0.0062 & 0.7160 & 0.6850 \\
\hline 9. $C C_{-} A C M$ & -0.0204 & -0.0454 & -0.0089 & 0.1057 & 0.4483 & 0.0485 & 0.0391 & 0.0262 & 1 & -0.0425 & 0.0375 \\
\hline 10. CC_AR & 0.4655 & 0.4335 & 0.0407 & -0.2084 & -0.0901 & -0.2359 & -0.0060 & 0.4056 & -0.0591 & 1 & 0.0426 \\
\hline 11. $C C C R$ & 0.1922 & 0.2145 & 0.0080 & -0.0299 & 0.0336 & -0.0426 & -0.0043 & 0.9305 & 0.0245 & 0.1167 & 1 \\
\hline
\end{tabular}

$E D F$ is the ranking of the expected one-year-ahead default probability from Merton (1974) model. Campbell is the ranking of the one-month-ahead probability of business failure calculated based on the formula in the last column of Table III in Campbell et al. (2008). BANK proxies for bankruptcy risk and is equal to one if the firm files for bankruptcy under Chapter 11 or Chapter 7 of the U.S. Bankruptcy code, and zero otherwise. UC_PCA is the factor score generated from a principal component analysis of the three unconditional conservatism measurements: $U C \_A C C, U C \_B M$ and $U C_{-} R E S$. Their eigenvalues are $0.9539,1.1433$ and 0.9028 ; their eigenvectors are 0.5380 , 0.6342 and 0.6721 ; and their final communality estimates are $0.2894,0.4022$ and 0.4517 , respectively. $U C \_A C C$ is equal to minus one times the ratio of total accruals to average total assets, calculated over a rolling window of the current year and prior two years. $U C_{-} B M$ is the industry-adjusted ranking of minus one times the ratio of book to market value of common shareholders' equity at fiscal year-end. UC_RES is the ratio of LIFO reserves plus hidden R\&D and advertising reserves resulting from the application of unconditional conservatism to total assets, estimated as follows: $U C_{-} R E S_{i t}=\left(I N V_{i t}^{\text {res }}+R D_{i t}^{\text {res }}+A D V_{i t}^{\text {res }}\right) / A T_{i t}$. CC_PCA is the factor score generated from a principal component analysis of the three conditional conservatism measurements: $C C_{-} A C M, C C_{-} A R$, and $C C_{-} C R$. Their eigenvalues are $1.0461,1.0324$, and 0.9214 ; their eigenvectors are $0.317 \overline{6}, 0.5468,0.8040$; and their final communality estimates are $0.1008,0.2990$, and 0.6464 , respectively. $C C A C M$ is minus one times the ratio of accumulated non-operating accruals to accumulated total assets, calculated over a rolling window of current year and prior two years. $C C A A R$ is the ratio of $\mathrm{C}$ score plus $\mathrm{G}$ score to $\mathrm{G}$ score as defined in Khan and Watts (2009), using the formula in Table 3 of Khan and Watts (2009) to calculate the $C C_{-} A R . C C \_C R$ is the ratio of unexpected current earnings (or current earnings shocks) to total earnings news with the ratio times minus one if earnings news is positive. $\operatorname{Ln}(M V)$ is the natural logarithm of market capitalization at the end of the fiscal year. Leverage is measured as the ratio of book value of long-term debt (Compustat DLTT) and short-term debt (Compustat DLC) to total assets (Compustat AT). ROA is the ratio of earnings (Compustat NI) over total assets (Compustat AT). $S T D \_$Ret is the annualized standard deviation of daily stock return over the prior twelve months. Cash is the ratio of cash holdings (Compustat CHE) to total assets (Compustat AT). $\Delta$ Cash is the ratio of cash flow (Compustat $\mathrm{CHECH}$ ) to total assets (Compustat AT). Rate is the risk-free rate measured by the annualized three-month T-bill rate retrieved from Federal Reserve Bank Reports. Inten_RD is the ratio of R\&D expenses (Compustat XRD) to total assets (Compustat AT). SOX is an indicator for the period after the passage of the SOX Act, equal to 1 for fiscal years 2003 and after, and 0 otherwise. Aud_Resign is an indicator for an auditor's resignation from a client firm equal to 1 for the three-year period after auditor resignation and 0 otherwise. Emgmt is the factor score generated from a principal component analysis of four earnings management metrics: the ranking of absolute value of discretionary accrual DA, abnormal operational cash flow R_OCF, abnormal discretionary expenses $R \_D I S X$, and abnormal product cost R_PROD. Their eigenvalues are 1.2992, 1.1747, 0.8823 and 0.6438; their eigenvectors are $0.2138,-0.7195,0.8136$ and -0.2691 ; and their final communality estimates are $0.0473,0.5177,0.6619$ and 0.0724, respectively. Esmooth proxies for conservatism gaming and is measured as negative one times the Spearman correlation of OCF and accruals with both deflated by average total assets, measured using a rolling window of five fiscal years for all available accrual and cash flow data. Volatility_ROA proxies for earnings variability estimated as the variance of $R O A$ calculated over a rolling window of the current year and prior four years. SPOS is an indicator for small positive earnings that equals one if net income scaled by total assets is 
between 0 and 0.01 , following Barth et al. (2008). Turn is measured as sales (Compustat SALE) divided by end-ofyear total assets (Compustat AT), following Barth et al. (2008). Eissue is annual percentage change in shares of common stock measured as the ratio of the change in shares outstanding at the current and previous fiscal year-ends to the common shares outstanding at previous fiscal year-end (Compustat CSHO). Dissue is annual change in total liabilities (Compustat LT) deflated by beginning-of-year total liabilities, following Barth et al. (2008). Growth is annual change in sales (Compustat SALE) deflated by sales in previous period. Nimtaavg proxies for earnings predictability defined as the present value of the three-year sum of NIMTA, the annual net income deflated by total liabilities and market value, assuming earnings degenerate at the monthly rate $\phi=1 / 2$ : Nimtaavg $=\frac{1-\phi^{12}}{1-\phi^{24}}\left(\right.$ NIMTA $_{-1, t-2}+\phi^{12}$ NIMTA $\left._{-2, t-3}+\phi^{24} N I M T A_{-3, t-4}\right)$. Exretavg proxies for return predictability of EXRET (past excess return relative to the value weighted S\&P 500 index return over a period of 12 months), and Exretavg $=\frac{1-\phi}{1-\phi^{12}}\left(E X R E T_{-1}+\ldots+\phi^{11} E X R E T_{-12}\right)$, where $E X R E T_{i t}=\log \left(1+R_{i t}\right)-\log \left(1+R_{S \& P 500, t}\right)$, and $\phi=1 / 2$. Rsize proxies

for relative firm size calculated as the natural logarithm of market value of equity relative to that of the S\&P 500 index. $M b$ is the ratio of firm's market equity value to its book equity value at fiscal year-end. Price is calculated as the log of price per share winsorised above \$15, following Campbell et al. (2008). 


\section{Table 2 Causal Relations between Unconditional and Conditional Conservatism and Bankruptcy Risk Estimated by VARX (1) Models}

This table reports SUR estimation results for tri-variate VARX (1) models. Bankruptcy risk measures are EDF and Campbell; unconditional and conditional conservatism measures are UC_PCA and CC_PCA, respectively. Model 1 uses $E D F, U C P C A$, and $C C_{P} P C A$ as dependent variables and their one-period lags as autoregressive vectors; Model 2 uses Campbell, UC_PCA, and CC_PCA as dependent variables and their one-period lags as autoregressive vectors. Panel A reports the results for the full sample; Panel B reports the results for the extremely distressed subsample of firm-year observations in the highest decile of $(-R O A)$. Model details are provided below.

\begin{tabular}{|c|c|c|c|c|c|c|}
\hline \multicolumn{7}{|c|}{ Panel A: Tri-variate VARX (1) Model Results for the Full Sample } \\
\hline \multirow{2}{*}{$\begin{array}{l}\text { Independent } \\
\text { Variables } \\
\end{array}$} & \multicolumn{3}{|c|}{\begin{tabular}{|c|} 
Model 1 \\
\end{tabular}} & \multicolumn{3}{|c|}{ Model 2} \\
\hline & $E D F_{t}$ & $U \boldsymbol{C}_{-} \boldsymbol{P C A _ { t }}$ & CC_PCA & Campbell & $U C_{-} P C A_{t}$ & $C C_{-} P C A_{t}$ \\
\hline Intercept & $\begin{array}{l}0.3532 \\
(17.21)^{* * *}\end{array}$ & $\begin{array}{l}0.0191 \\
(3.73)^{* * *}\end{array}$ & $\begin{array}{l}2.9846 \\
(46.56)^{* * *}\end{array}$ & $\begin{array}{l}0.3842 \\
(18.10)^{* * *}\end{array}$ & $\begin{array}{l}0.0213 \\
(4.23)^{* * *}\end{array}$ & $\begin{array}{l}3.0627 \\
(48.60)^{* * *}\end{array}$ \\
\hline$U C_{-} P C A t-1$ & $\begin{array}{l}-0.0431 \\
(-8.82)^{* * * *}\end{array}$ & $\begin{array}{l}0.6616 \\
(186.62)^{* * *}\end{array}$ & $\begin{array}{l}0.0940 \\
(2.12)^{* * *}\end{array}$ & $\begin{array}{l}-0.0184 \\
(-3.65)^{* * * *}\end{array}$ & $\begin{array}{l}0.6619 \\
(186.70)^{* * *}\end{array}$ & $\begin{array}{l}0.0571 \\
(1.29)\end{array}$ \\
\hline$C C_{-} P C A_{t-1}$ & $\begin{array}{l}-0.0083 \\
(-15.05)^{* * *}\end{array}$ & $\begin{array}{l}0.0021 \\
(5.17)^{* * *}\end{array}$ & $\begin{array}{l}-0.0128 \\
(-2.56)^{* * *}\end{array}$ & $\begin{array}{l}-0.0111 \\
(-19.38)^{* * *}\end{array}$ & $\begin{array}{l}0.0019 \\
(4.67)^{* * *}\end{array}$ & $\begin{array}{l}-0.0076 \\
(-1.52)\end{array}$ \\
\hline$E D F_{t-1}$ & $\begin{array}{l}0.2459 \\
(62.20)^{* * *}\end{array}$ & $\begin{array}{l}0.0389 \\
(13.61)^{* * *}\end{array}$ & $\begin{array}{l}-0.2865 \\
(-8.01)^{* * *}\end{array}$ & & & \\
\hline Campbell $_{t-1}$ & & & & $\begin{array}{l}0.3340 \\
(85.31)^{* * *}\end{array}$ & $\begin{array}{l}0.0388 \\
(14.16)^{* * *}\end{array}$ & $\begin{array}{l}-0.4431 \\
(-12.95) * * *\end{array}$ \\
\hline $\operatorname{Ln}(M V)_{t}$ & $\begin{array}{l}-0.0377 \\
(-64.60)^{* * *}\end{array}$ & $\begin{array}{l}0.0162 \\
(39.85)^{* * *}\end{array}$ & $\begin{array}{l}-0.2663 \\
(-52.33)^{* * *}\end{array}$ & $\begin{array}{l}-0.0305 \\
(-51.88)^{* * *}\end{array}$ & $\begin{array}{l}0.0156 \\
(39.76)^{* * *}\end{array}$ & $\begin{array}{l}-0.2673 \\
(-54.53)^{* * *}\end{array}$ \\
\hline Leverage $_{t}$ & $\begin{array}{l}0.6452 \\
(95.17)^{* * *}\end{array}$ & $\begin{array}{l}-0.0636 \\
(-13.39)^{* * *}\end{array}$ & $\begin{array}{l}0.3180 \\
(5.35)^{* * *}\end{array}$ & $\begin{array}{l}0.4687 \\
(67.79)^{* * *}\end{array}$ & $\begin{array}{l}-0.0634 \\
(-13.40)^{* * *}\end{array}$ & $\begin{array}{l}0.4000 \\
(6.77)^{* * *}\end{array}$ \\
\hline$R O A_{t}$ & $\begin{array}{l}-0.4263 \\
(-33.93)^{* * *}\end{array}$ & $\begin{array}{l}-0.2552 \\
(-28.33)^{* * *}\end{array}$ & $\begin{array}{l}-6.5643 \\
(-58.21)^{* * *}\end{array}$ & $\begin{array}{l}-0.9634 \\
(-73.09)^{* * *}\end{array}$ & $\begin{array}{l}-0.2437 \\
(-26.70) * * *\end{array}$ & $\begin{array}{l}-6.7519 \\
(-59.17)^{* * *}\end{array}$ \\
\hline$S T D \_$Ret $_{t}$ & $\begin{array}{l}0.3201 \\
(77.46)^{* * *}\end{array}$ & & & $\begin{array}{l}0.1702 \\
(40.06)^{* * *}\end{array}$ & & \\
\hline $\operatorname{Cash}_{t}$ & $\begin{array}{l}-0.0395 \\
(-4.35)^{* * *}\end{array}$ & & & $\begin{array}{l}-0.3210 \\
(-33.95) * * *\end{array}$ & & \\
\hline$\triangle$ Cash $_{t}$ & $\begin{array}{l}-0.0600 \\
(-4.39)^{* * *}\end{array}$ & & & $\begin{array}{l}-0.1348 \\
(-9.52)^{* * *}\end{array}$ & & \\
\hline Rate $_{t}$ & $\begin{array}{l}-1.1966 \\
(-5.05)^{* * *}\end{array}$ & & & $\begin{array}{l}-0.0947 \\
(-0.39)\end{array}$ & & \\
\hline Inten_RD $D_{t}$ & $\begin{array}{l}-0.0005 \\
(-0.97)\end{array}$ & $\begin{array}{l}0.0023 \\
(6.11)^{* * *}\end{array}$ & $\begin{array}{l}-0.0085 \\
(-1.78)^{*}\end{array}$ & $\begin{array}{l}-0.0011 \\
(-2.05)^{* *}\end{array}$ & $\begin{array}{l}0.0024 \\
(6.23)^{* * *}\end{array}$ & $\begin{array}{l}-0.0090 \\
(-1.89)^{*}\end{array}$ \\
\hline $\begin{array}{l}\text { Year and Ind Dum } \\
F \text {-statistic }\end{array}$ & $\begin{array}{l}\text { Yes } \\
157.52 * * *\end{array}$ & $\begin{array}{l}\text { Yes } \\
185.30^{* * *}\end{array}$ & $\begin{array}{l}\text { Yes } \\
64.13^{* * *}\end{array}$ & $\begin{array}{l}\text { Yes } \\
197.75^{* * *}\end{array}$ & $\begin{array}{l}\text { Yes } \\
200.64 * * *\end{array}$ & $\begin{array}{l}\text { Yes } \\
167.79 * * *\end{array}$ \\
\hline $\begin{array}{l}\text { Sample size } \\
\text { Sys. weighted } \mathrm{R}^{2}\end{array}$ & & $\begin{array}{l}34,896 \\
0.6109 \\
\end{array}$ & & & $\begin{array}{l}34,890 \\
0.5994 \\
\end{array}$ & \\
\hline \multicolumn{7}{|c|}{ Panel B: Tri-variate VARX (1) Model Results for the Extremely Distressed Subsample } \\
\hline \multirow{2}{*}{$\begin{array}{l}\text { Independent } \\
\text { Variables } \\
\end{array}$} & \multicolumn{3}{|c|}{\begin{tabular}{|c|} 
Model 1 \\
\end{tabular}} & \multicolumn{3}{|c|}{ Model 2 } \\
\hline & $\boldsymbol{E D F}_{t}$ & $U C_{-} P C_{A}$ & CC_PCA $A_{t}$ & Campbell & $U C_{-} P C A_{t}$ & CC_PCA \\
\hline Intercept & $\begin{array}{l}0.2011 \\
(3.49)^{* * *}\end{array}$ & $\begin{array}{l}0.0919 \\
(5.27)^{* * *}\end{array}$ & $\begin{array}{l}3.0555 \\
(12.16)^{* * *}\end{array}$ & $\begin{array}{l}0.2267 \\
(3.65)^{* * *}\end{array}$ & $\begin{array}{l}0.0932 \\
(5.40)^{* * *}\end{array}$ & $\begin{array}{l}3.1876 \\
(12.83)^{* * *}\end{array}$ \\
\hline$U C_{-} P C A_{t-1}$ & $\begin{array}{l}-0.0356 \\
(-2.36)^{* *}\end{array}$ & $\begin{array}{l}0.5715 \\
(51.83)^{* * *}\end{array}$ & $\begin{array}{l}0.1176 \\
(0.74)\end{array}$ & $\begin{array}{l}-0.0090 \\
(-0.56)\end{array}$ & $\begin{array}{l}0.5709 \\
(51.92)^{* * *}\end{array}$ & $\begin{array}{l}0.0864 \\
(0.55)\end{array}$ \\
\hline$C C_{-} P C A_{t-1}$ & $\begin{array}{l}-0.0086 \\
(-5.33)^{* * *}\end{array}$ & $\begin{array}{l}0.0019 \\
(1.65)\end{array}$ & $\begin{array}{l}0.0099 \\
(0.58)\end{array}$ & $\begin{array}{l}-0.0096 \\
(-5.53) * * *\end{array}$ & $\begin{array}{l}0.0019 \\
(1.57)\end{array}$ & $\begin{array}{l}0.0158 \\
(0.93)\end{array}$ \\
\hline$E D F_{t-1}$ & $\begin{array}{l}0.2189 \\
(19.14)^{* * *}\end{array}$ & $\begin{array}{l}0.0299 \\
(3.59) * * *\end{array}$ & $\begin{array}{l}-0.1227 \\
(-1.02)\end{array}$ & & & \\
\hline Campbell $_{t-1}$ & & & & $\begin{array}{l}0.2409 \\
(20.77)^{* * *}\end{array}$ & $\begin{array}{l}0.0299 \\
(3.79)^{* * *}\end{array}$ & $\begin{array}{l}-0.3508 \\
(-3.09) * * *\end{array}$ \\
\hline Leverage $_{t}$ & $\begin{array}{l}-0.0400 \\
(-23.96)^{* * *} \\
0.8631 \\
(33.78)^{* * *}\end{array}$ & $\begin{array}{l}0.0136 \\
(11.31)^{* * *} \\
0.0031 \\
(0.17)\end{array}$ & $\begin{array}{l}-0.2302 \\
(-13.31)^{* * *} \\
-1.1485 \\
(-4.36)^{* * *}\end{array}$ & $\begin{array}{l}-0.0305 \\
(-17.48)^{* * *} \\
0.4519 \\
(16.81)^{* * *}\end{array}$ & $\begin{array}{l}0.0133 \\
(11.46)^{* * *} \\
0.0059 \\
(0.33)\end{array}$ & $\begin{array}{l}-0.2420 \\
(-14.43)^{* * *} \\
-1.0447 \\
(-4.03)^{* * *}\end{array}$ \\
\hline
\end{tabular}




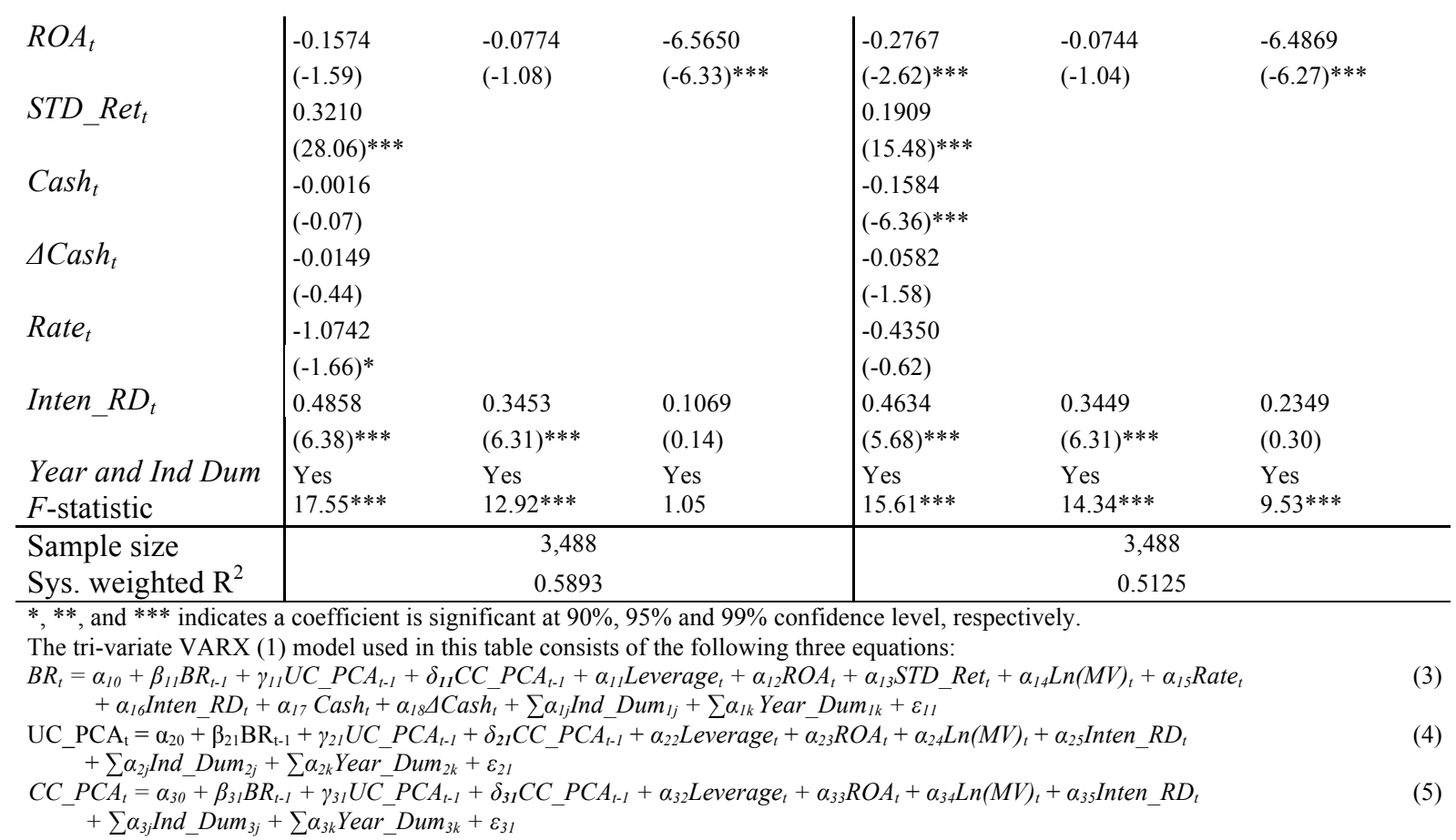

where $B R=E D \bar{F}$ in Model 1 and $B \bar{R}=$ Campbell in Model 2 .

$F$-statistics reported in columns 2 and 5 are for $\mathrm{H} 0: \gamma_{11}=0$ and $\delta_{11}=0 ; F$-statistics reported in columns 3 and 6 are for $\mathrm{H} 0: \delta_{2 l}=0$, and $F$ statistics reported in columns 4 and 7 are for $\mathrm{H} 0: \gamma_{31}=0$. 


\section{Table 3 Causal Relations between Unconditional and Conditional Conservatism and Bankruptcy Risk for Full Samples Estimated by VARX (3) Models}

This table reports SUR estimation results for tri-variate VARX (3) models. Bankruptcy risk measures are EDF and Campbell; unconditional and conditional conservatism measures are UC PCA and CC PCA, respectively. Model 1 uses $E D F, U C_{-} P C A$, and $C C_{-} P C A$ as dependent variables and their one-, two-, three-period lags as autoregressive vectors; Model 2 uses Campbell, UC PCA, and CC PCA as dependent variables and their one-, two-, three-period lags as autoregressive vectors. Model details are provided below.

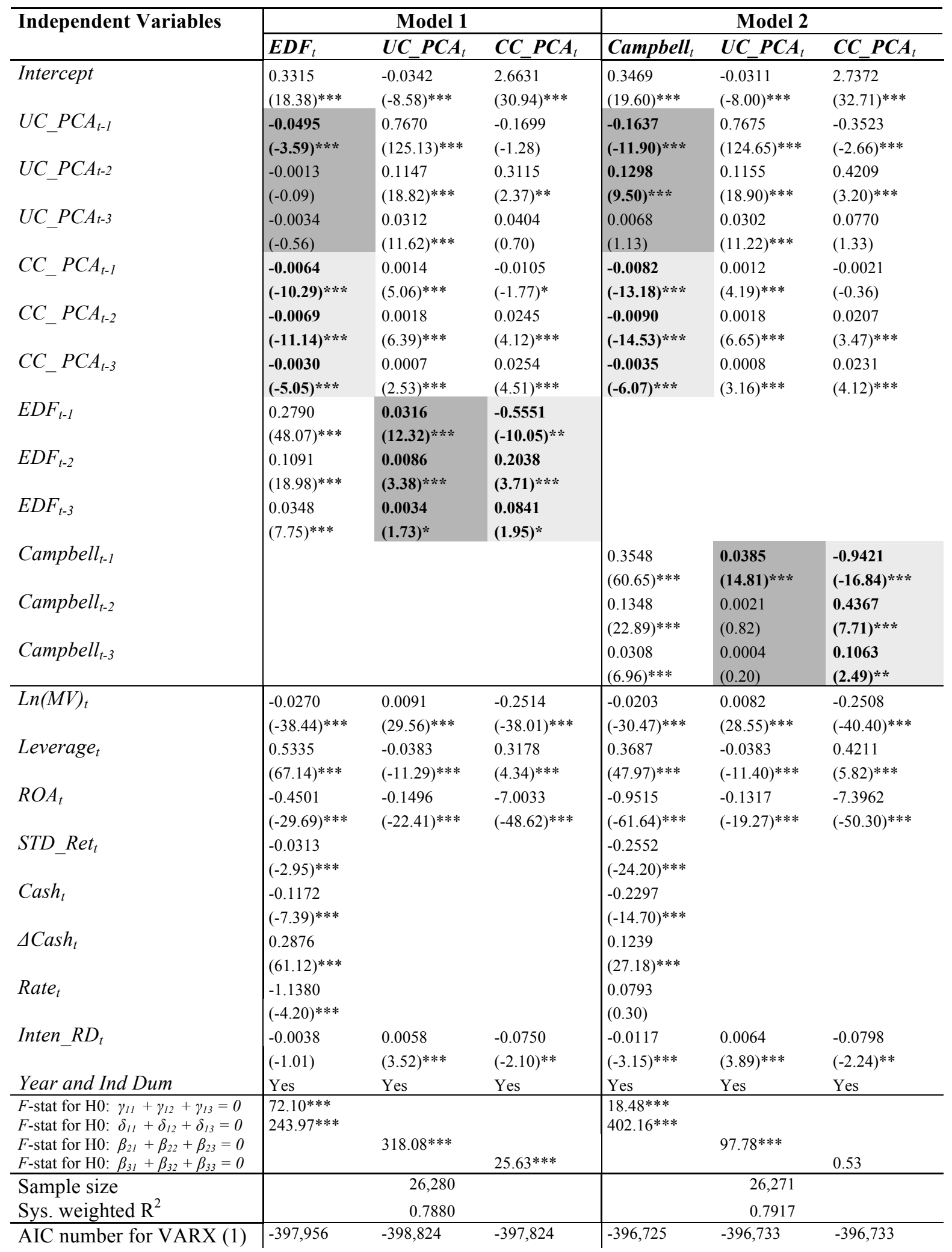




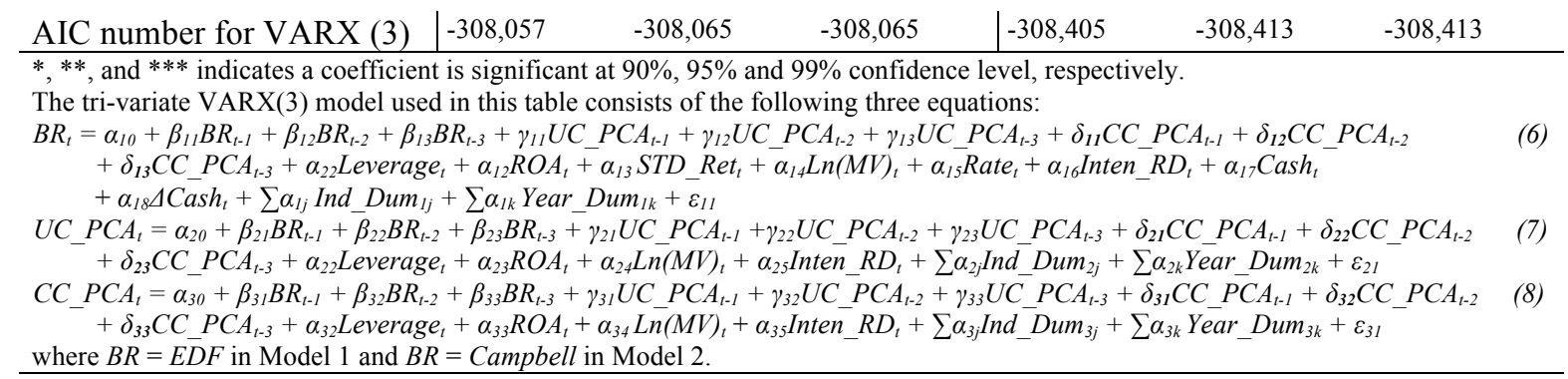




\section{Table 4 Causal Relations between Unconditional and Conditional Conservatism and Subsequent Actual Bankruptcy Estimated by Logit Models}

This table reports estimation results for logit models that regress the bankruptcy indicator $B A N K$ on unconditional and conditional conservatism metrics $U C_{-} P C A$ and $C_{-} P C A$ and control variables. As testing variables, Model 1 uses UC_PCA, Model 2 uses CC_PCA and Models 3 to 5 use both $U C_{-} P C A$ and $C C_{-} P C A$. Models 4 and 5 add earnings management (Emgmt) and earnings smoothing (Esmooth) as control variables, respectively. Model details are provided below.

\begin{tabular}{|c|c|c|c|c|c|}
\hline $\begin{array}{l}\text { Independent } \\
\text { Variables }\end{array}$ & Model 1 & Model 2 & Model 3 & Model 4 & Model 5 \\
\hline Intercept & $\begin{array}{l}-26.7094 \\
(-12.93)^{* * *}\end{array}$ & $\begin{array}{l}-26.8657 \\
(-13.01)^{* * *}\end{array}$ & $\begin{array}{l}-26.7027 \\
(-12.91)^{* * *}\end{array}$ & $\begin{array}{l}-26.7179 \\
(-12.80)^{* * *}\end{array}$ & $\begin{array}{l}-26.2651 \\
(-11.98)^{* * *}\end{array}$ \\
\hline$U C_{-} P C A_{t-1}$ & $\begin{array}{l}-1.0837 \\
(-2.38)^{* *}\end{array}$ & & $\begin{array}{l}-1.0844 \\
(-2.38)^{* *}\end{array}$ & $\begin{array}{l}-1.0763 \\
(-2.36)^{* *}\end{array}$ & $\begin{array}{l}-1.1358 \\
(-2.44)^{* *}\end{array}$ \\
\hline$C C_{-} P C A_{t-1}$ & & $\begin{array}{l}0.0026 \\
(0.06) \\
\end{array}$ & $\begin{array}{l}0.0045 \\
(0.10) \\
\end{array}$ & $\begin{array}{l}0.0035 \\
(0.08) \\
\end{array}$ & $\begin{array}{l}-0.0084 \\
(-0.19) \\
\end{array}$ \\
\hline $\begin{array}{l}\text { Emgmt }_{t-1} \\
\text { Esmooth }_{t-1}\end{array}$ & & & & $\begin{array}{l}0.1775 \\
(0.68)\end{array}$ & $\begin{array}{l}-0.3326 \\
(-1.00) \\
\end{array}$ \\
\hline Nimtaavg $_{t-1}$ & $\begin{array}{l}-1.8605 \\
(-1.48)\end{array}$ & $\begin{array}{l}-1.8098 \\
(-1.46)\end{array}$ & $\begin{array}{l}-1.8543 \\
(-1.47)\end{array}$ & $\begin{array}{l}-1.8134 \\
(-1.44)\end{array}$ & $\begin{array}{l}-1.8142 \\
(-1.36)\end{array}$ \\
\hline Leverage $_{t-1}$ & $\begin{array}{l}1.8871 \\
(2.46)^{* *}\end{array}$ & $\begin{array}{l}1.8253 \\
(2.39)^{* *}\end{array}$ & $\begin{array}{l}1.8850 \\
(2.47)^{* *}\end{array}$ & $\begin{array}{l}1.8818 \\
(2.46)^{* *}\end{array}$ & $\begin{array}{l}2.2959 \\
(2.73)^{* * *}\end{array}$ \\
\hline Exretavg $_{t-1}$ & $\begin{array}{l}-6.5512 \\
(-2.32)^{* *}\end{array}$ & $\begin{array}{l}-6.3473 \\
(-2.24)^{* *}\end{array}$ & $\begin{array}{l}-6.5619 \\
(-2.32)^{* *}\end{array}$ & $\begin{array}{l}-6.6528 \\
(-2.34)^{* *}\end{array}$ & $\begin{array}{l}-6.0151 \\
(-2.06)^{* *}\end{array}$ \\
\hline Rsize $_{t-1}$ & $\begin{array}{l}-0.2951 \\
(-3.20)^{* * *}\end{array}$ & $\begin{array}{l}-0.3035 \\
(-3.30)^{* * *}\end{array}$ & $\begin{array}{l}-0.2939 \\
(-3.14)^{* * *}\end{array}$ & $\begin{array}{l}-0.2884 \\
(-3.03)^{* * *}\end{array}$ & $\begin{array}{l}-0.3422 \\
(-3.51)^{* * *}\end{array}$ \\
\hline$S T D \_R_{t-1}$ & $\begin{array}{l}1.3001 \\
(3.30)^{* * *}\end{array}$ & $\begin{array}{l}1.2614 \\
(3.18)^{* * *}\end{array}$ & $\begin{array}{l}1.2989 \\
(3.29)^{* * *}\end{array}$ & $\begin{array}{l}1.2946 \\
(3.25)^{* * *}\end{array}$ & $\begin{array}{l}1.2937 \\
(3.00)^{* * *}\end{array}$ \\
\hline $\operatorname{Cash}_{t-1}$ & $\begin{array}{l}-5.0233 \\
(-3.40)^{* * *}\end{array}$ & $\begin{array}{l}-4.8829 \\
(-3.34)^{* * *}\end{array}$ & $\begin{array}{l}-5.0187 \\
(-3.39)^{* * *}\end{array}$ & $\begin{array}{l}-4.8938 \\
(-3.31)^{* * *}\end{array}$ & $\begin{array}{l}-4.6751 \\
(-3.17)^{* * *}\end{array}$ \\
\hline$\Delta \operatorname{Cash}_{t-1}$ & $\begin{array}{l}3.4642 \\
(1.34)\end{array}$ & $\begin{array}{l}3.3340 \\
(1.31)\end{array}$ & $\begin{array}{l}3.4604 \\
(1.34)\end{array}$ & $\begin{array}{l}3.3898 \\
(1.32)\end{array}$ & $\begin{array}{l}3.7284 \\
(1.41)\end{array}$ \\
\hline$M b_{t-1}$ & $\begin{array}{l}0.0633 \\
(0.25)\end{array}$ & $\begin{array}{l}0.0068 \\
(0.03)\end{array}$ & $\begin{array}{l}0.0627 \\
(0.24)\end{array}$ & $\begin{array}{l}0.0776 \\
(0.31)\end{array}$ & $\begin{array}{l}0.2711 \\
(1.08)\end{array}$ \\
\hline Price $_{t-1}$ & $\begin{array}{l}0.8508 \\
(3.42)^{* * *}\end{array}$ & $\begin{array}{l}0.8303 \\
(3.34)^{* * *}\end{array}$ & $\begin{array}{l}0.8510 \\
(3.42)^{* * *}\end{array}$ & $\begin{array}{l}0.8422 \\
(3.37)^{* * *}\end{array}$ & $\begin{array}{l}0.8439 \\
(3.21)^{* * *}\end{array}$ \\
\hline Rate $_{t-1}$ & $\begin{array}{l}35.4836 \\
(1.00)\end{array}$ & $\begin{array}{l}34.0016 \\
(0.97)\end{array}$ & $\begin{array}{l}35.5005 \\
(1.00)\end{array}$ & $\begin{array}{l}35.7905 \\
(1.00)\end{array}$ & $\begin{array}{l}34.9742 \\
(0.91)\end{array}$ \\
\hline $\begin{array}{l}\text { Inten_RD } D_{t-1} \\
\text { Year and Ind Dum }\end{array}$ & $\begin{array}{r}-19.1577 \\
(-2.09)^{* *} \\
\text { Yes } \\
\end{array}$ & $\begin{array}{r}-19.6993 \\
(-2.22)^{* *} \\
\text { Yes } \\
\end{array}$ & $\begin{array}{r}-19.1563 \\
(-2.09)^{* *} \\
\text { Yes } \\
\end{array}$ & $\begin{array}{r}-18.9446 \\
(-2.04)^{* *} \\
\text { Yes } \\
\end{array}$ & $\begin{array}{r}-18.4807 \\
(-2.06)^{* *} \\
\text { Yes } \\
\end{array}$ \\
\hline Obs. & 30,986 & 30,986 & 30,986 & 30,941 & 29,614 \\
\hline Bankruptcy obs. & 205 & 205 & 205 & 205 & 205 \\
\hline Psuedo $R$-square & 0.2422 & 0.2392 & 0.2422 & 0.2428 & 0.2586 \\
\hline \multicolumn{6}{|c|}{ 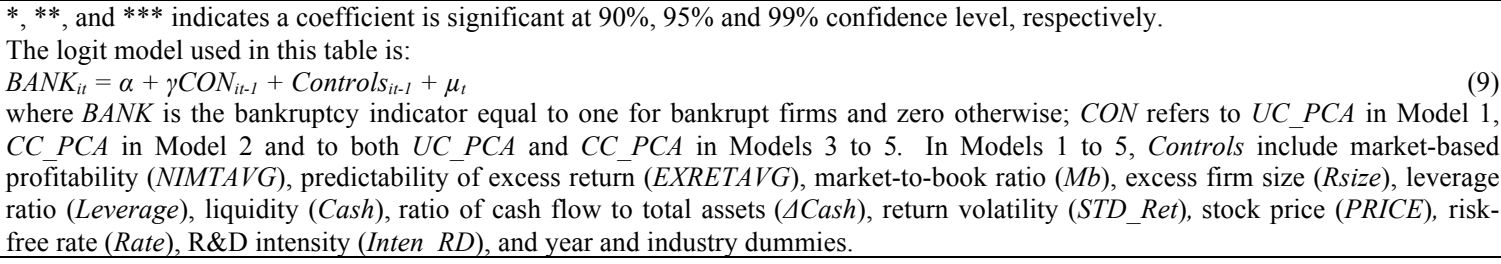 } \\
\hline
\end{tabular}




\section{Table 5 Cash Enhancing and Informational Roles of Accounting Conservatism and Causal Relations between Unconditional and Conditional Conservatism and Subsequent Bankruptcy Risk}

This table reports SUR estimation results for tri-variate VARX (1) models using conditional and unconditional conservatism, bankruptcy risk and their interactions with cash or information asymmetry as autoregressive vectors. Bankruptcy risk measures are $E D F$ and Campbell; unconditional and conditional conservatism measurements are $U C_{-} P C A$ and $C C_{-} P C A$, respectively. Model details are provided below.

\begin{tabular}{|c|c|c|c|c|c|c|}
\hline \multicolumn{7}{|c|}{ Panel A: Tests for Cash Enhancing Role of Conservatism } \\
\hline \multirow[t]{2}{*}{ Independent Variables } & \multicolumn{3}{|c|}{\begin{tabular}{|c|} 
Model 1 \\
\end{tabular}} & \multicolumn{3}{|c|}{ Model 2} \\
\hline & $E \boldsymbol{D D F}$ & $U \boldsymbol{C}_{-} \boldsymbol{P C} \boldsymbol{A}_{t}$ & CC_PCA $A_{t}$ & Campbell & $U \boldsymbol{U} \boldsymbol{P}_{-} \boldsymbol{P C A _ { t }}$ & CC_PCA $\boldsymbol{A}_{t}$ \\
\hline Intercept & $\begin{array}{l}0.2944 \\
(13.92)^{* * *}\end{array}$ & $\begin{array}{l}-0.0308 \\
(-8.27)^{* * *}\end{array}$ & $\begin{array}{l}3.0679 \\
(39.82)^{* * *}\end{array}$ & $\begin{array}{l}0.3040 \\
(14.43)^{* * *}\end{array}$ & $\begin{array}{l}-0.0296 \\
(-8.04)^{* * *}\end{array}$ & $\begin{array}{l}3.1702 \\
(41.68)^{* * * *}\end{array}$ \\
\hline$U C_{-} P C A_{t-1} * \mathrm{Cash}_{t-1}$ & $\begin{array}{l}-0.3010 \\
(-9.46)^{* * * *}\end{array}$ & & & $\begin{array}{l}-0.3437 \\
(-10.85)^{* * *}\end{array}$ & & \\
\hline$U C_{-} P C A_{t-1}$ & $\begin{array}{l}-0.0321 \\
(-5.06)^{* * *}\end{array}$ & $\begin{array}{l}0.8838 \\
(354.25)^{* * *}\end{array}$ & $\begin{array}{l}0.0997 \\
(1.93)^{*}\end{array}$ & $\begin{array}{l}-0.0067 \\
(-1.06)\end{array}$ & $\begin{array}{l}0.8839 \\
(354.90)^{* * *}\end{array}$ & $\begin{array}{l}0.0620 \\
(1.20)\end{array}$ \\
\hline$C C_{-} P C A_{t-1} * \operatorname{Cash}_{t-1}$ & $\begin{array}{l}-0.0276 \\
(-5.83) * * *\end{array}$ & & & $\begin{array}{l}-0.0115 \\
(-2.44) * *\end{array}$ & & \\
\hline$C C_{-} P C A_{t-1}$ & $\begin{array}{l}-0.0050 \\
(-7.02)^{* * *}\end{array}$ & $\begin{array}{l}0.0010 \\
(3.66)^{* * *}\end{array}$ & $\begin{array}{l}-0.0146 \\
(-2.62)^{* * *}\end{array}$ & $\begin{array}{l}-0.0092 \\
(-12.93)^{* * *}\end{array}$ & $\begin{array}{l}0.0008 \\
(2.89)^{* * *}\end{array}$ & $\begin{array}{l}-0.0099 \\
(-1.77)^{*}\end{array}$ \\
\hline$E D F_{t-1}$ & $\begin{array}{l}0.3527 \\
(77.54)^{* * *}\end{array}$ & $\begin{array}{l}0.0438 \\
(21.35)^{* * *}\end{array}$ & $\begin{array}{l}-0.3785 \\
(-8.93)^{* * *}\end{array}$ & & & \\
\hline Controls & Yes & Yes & Yes & $\begin{array}{l}0.4619 \\
(107.04)^{* * *} \\
\text { Yes } \\
\end{array}$ & $\begin{array}{l}0.0432 \\
(22.48)^{* * *} \\
\text { Yes } \\
\end{array}$ & $\begin{array}{l}-0.5588 \\
(-14.08)^{* * *} \\
\text { Yes }\end{array}$ \\
\hline $\begin{array}{l}F \text {-statistic for } \mathrm{H} 0: \theta_{11}+\gamma_{11}=0 \\
F \text {-statistic for } \mathrm{H} 0: \delta_{11}+\theta_{12}=0\end{array}$ & & $\begin{array}{r}131.31 * * * \\
55.70 * * * \\
\end{array}$ & & & $\begin{array}{l}146.52^{* * *} \\
22.64 * * *\end{array}$ & \\
\hline $\begin{array}{l}\text { Sample size } \\
\text { Sys. weighted } \mathrm{R}^{2}\end{array}$ & & $\begin{array}{l}30,276 \\
0.6018\end{array}$ & & & $\begin{array}{l}30,270 \\
0.5893\end{array}$ & \\
\hline \multicolumn{7}{|c|}{ Panel B: Tests for Information Role of Conservatism } \\
\hline \multirow[t]{2}{*}{ Independent Variables } & & Model 1 & & & Model 2 & \\
\hline & $E \boldsymbol{E D F}$ & $U C_{-} P C_{A}$ & CC_PCA $A_{t}$ & Campbell & $U C_{-} P C_{A}$ & CC_PCA \\
\hline Intercept & $\begin{array}{l}0.3039 \\
(14.29)^{* * *}\end{array}$ & $\begin{array}{l}-0.0308 \\
(-8.27)^{* * *}\end{array}$ & $\begin{array}{l}3.0679 \\
(39.82)^{* * *}\end{array}$ & $\begin{array}{l}0.3198 \\
(15.07)^{* * * *}\end{array}$ & $\begin{array}{l}-0.0296 \\
(-8.04)^{* * *}\end{array}$ & $\begin{array}{l}3.1702 \\
(41.68)^{* * *}\end{array}$ \\
\hline$U C \_P C A_{t-1} * S T D \_$Ret $_{t-1}$ & $\begin{array}{l}-0.0453 \\
(-3.00) * * *\end{array}$ & & & $\begin{array}{l}-0.1367 \\
(-9.07)^{* * *}\end{array}$ & & \\
\hline$U C_{-} P C A_{t-1}$ & $\begin{array}{l}-0.0305 \\
(-3.20)^{* * *}\end{array}$ & $\begin{array}{l}0.8838 \\
(354.25)^{* * *}\end{array}$ & $\begin{array}{l}0.0997 \\
(1.93)^{*}\end{array}$ & $\begin{array}{l}0.0346 \\
(3.65)^{* * *}\end{array}$ & $\begin{array}{l}0.8839 \\
(354.90)^{* * *}\end{array}$ & $\begin{array}{l}0.0620 \\
(1.20)\end{array}$ \\
\hline CC_PCA $A_{t-1} * S T D \_$Ret $_{t-1}$ & $\begin{array}{l}-0.0201 \\
(-10.56)^{* * *}\end{array}$ & & & $\begin{array}{l}-0.0004 \\
(-0.20)\end{array}$ & & \\
\hline$C C_{-} P C A_{t-1}$ & $\begin{array}{l}0.0026 \\
(2.40)^{* *}\end{array}$ & $\begin{array}{l}0.0010 \\
(3.66)^{* * *}\end{array}$ & $\begin{array}{l}-0.0146 \\
(-2.62)^{* * *}\end{array}$ & $\begin{array}{l}-0.0097 \\
(-8.95)^{* * *}\end{array}$ & $\begin{array}{l}0.0008 \\
(2.89)^{* * *}\end{array}$ & $\begin{array}{l}-0.0099 \\
(-1.77)^{*}\end{array}$ \\
\hline$E D F_{t-1}$ & $\begin{array}{l}0.3760 \\
(77.80)^{* * *}\end{array}$ & $\begin{array}{l}0.0438 \\
(21.35)^{* * *}\end{array}$ & $\begin{array}{l}-0.3785 \\
(-8.93)^{* * *}\end{array}$ & & & \\
\hline Campbell $_{t-1}$ & Yes & Yes & Yes & $\begin{array}{l}0.4666 \\
(106.88)^{* * *} \\
\text { Yes } \\
\end{array}$ & $\begin{array}{l}0.0432 \\
(22.48)^{* * *} \\
\text { Yes }\end{array}$ & $\begin{array}{l}-0.5588 \\
(-14.08)^{* * *} \\
\text { Yes }\end{array}$ \\
\hline $\begin{array}{l}F \text {-statistic for } \mathrm{H} 0: \theta_{11}+\gamma_{11}=0 \\
F \text {-statistic for } \mathrm{H} 0: \delta_{11}+\theta_{12}=0\end{array}$ & & $\begin{array}{c}68.82 * * * \\
231.59 * * * \\
\end{array}$ & & & $\begin{array}{c}125.08^{* * *} \\
76.27 * * * \\
\end{array}$ & \\
\hline $\begin{array}{l}\text { Sample size } \\
\text { Sys. weighted } \mathrm{R}^{2}\end{array}$ & & $\begin{array}{l}30,276 \\
0.7761 \\
\end{array}$ & & & $\begin{array}{l}30,270 \\
0.7778 \\
\end{array}$ & \\
\hline \multicolumn{7}{|c|}{ 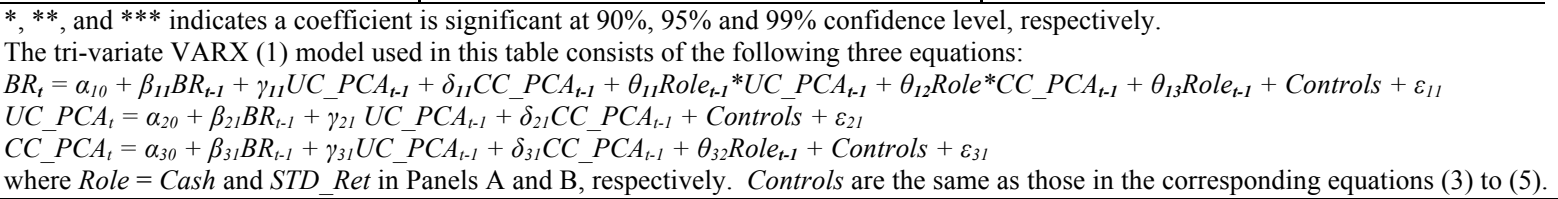 } \\
\hline
\end{tabular}




\section{Table 6 SOX, Auditor Resignations and Causal Relations between Bankruptcy Risk and Subsequent Unconditional and Conditional Conservatism}

This table reports SUR estimation results for tri-variate VARX (1) models with bankruptcy risk, unconditional and conditional conservatism as dependent variables, and with their one-period lags and interactions with post-SOX $(S O X)$ and post-auditor-resignation periods (Aud_resign) as autoregressive vectors. Bankruptcy risk measures are EDF and Campbell; unconditional and conditional conservatism measures are $U C_{-} P C A$ and $C C_{-} P C A$, respectively. Model details are provided below.

\begin{tabular}{|c|c|c|c|c|c|c|}
\hline \multicolumn{7}{|c|}{ Panel A: SOX and Causal Relations between Conservatism and Bankruptcy Risk } \\
\hline \multirow{2}{*}{ Independent Variables } & \multicolumn{3}{|c|}{ Model 1} & \multicolumn{3}{|c|}{ Model 2} \\
\hline & $E D F_{t}$ & $U C_{-} P C A_{t}$ & $C C_{-} P C A_{t}$ & Campbell $_{t}$ & $U C_{-} P C A_{t}$ & $C C_{-} P C A_{t}$ \\
\hline \multirow[t]{2}{*}{ Intercept } & 0.3505 & \multirow{3}{*}{$\begin{array}{l}0.0304 \\
(5.31)^{* * *}\end{array}$} & \multirow{3}{*}{$\begin{array}{l}2.9754 \\
(46.08)^{* * *}\end{array}$} & 0.3858 & \multirow{3}{*}{$\begin{array}{l}0.0318 \\
(5.65)^{* * *}\end{array}$} & \multirow{3}{*}{$\begin{array}{l}3.0675 \\
(48.38)^{* * *}\end{array}$} \\
\hline & $(17.04)^{* * *}$ & & & $(18.10)^{* * *}$ & & \\
\hline$U C \_P C A_{t-1} * S O X$ & $\begin{array}{l}-0.0322 \\
(-3.69) * * *\end{array}$ & & & $\begin{array}{l}0.0009 \\
(0.10)\end{array}$ & & \\
\hline$U C_{-} P C A_{t-1}$ & -0.0327 & \multirow{3}{*}{$\begin{array}{l}0.6636 \\
(184.04)^{* *}\end{array}$} & \multirow{3}{*}{$\begin{array}{l}0.1056 \\
(2.60)^{* * *}\end{array}$} & -0.0197 & \multirow{3}{*}{$\begin{array}{l}0.6641 \\
(184.19)^{* *}\end{array}$} & \multirow{3}{*}{$\begin{array}{l}0.0743 \\
(1.83)\end{array}$} \\
\hline \multirow[b]{2}{*}{$C C_{-} P C A_{t-1} * S O X$} & $(-6.67)^{* * *}$ & & & $(-3.89)^{* * *}$ & & \\
\hline & $\begin{array}{l}-0.0007 \\
(-0.56)\end{array}$ & & & $\begin{array}{l}-0.0040 \\
(-3.13)^{* * * *}\end{array}$ & & \\
\hline$C C_{-} P C A_{t-1}$ & $\begin{array}{l}-0.0081 \\
(-13.42)^{* *}\end{array}$ & $\begin{array}{l}0.0014 \\
(3.21)^{* * *}\end{array}$ & $\begin{array}{l}-0.0130 \\
(-2.58)^{* * *}\end{array}$ & $\begin{array}{l}-0.0102 \\
(-16.21)^{* *}\end{array}$ & \multirow[t]{3}{*}{$\begin{array}{l}0.0012 \\
(2.75)^{* * *}\end{array}$} & \multirow[t]{3}{*}{$\begin{array}{l}-0.0076 \\
(-1.51)\end{array}$} \\
\hline$E D F_{t-1} * S O X$ & & $\begin{array}{l}0.0105 \\
(1.81)^{*}\end{array}$ & $\begin{array}{l}-0.0261 \\
(-0.39)\end{array}$ & & & \\
\hline$E D F_{t-1}$ & $\begin{array}{l}0.2456 \\
(62.18)^{* * *}\end{array}$ & $\begin{array}{l}0.0316 \\
(9.04)^{* * *}\end{array}$ & $\begin{array}{l}-0.2777 \\
(-7.03)^{* * *}\end{array}$ & & & \\
\hline Campbell $_{t-1} * S O X$ & & & & & $\begin{array}{l}0.0135 \\
(2.37)^{* *}\end{array}$ & $\begin{array}{l}0.1041 \\
(1.59)\end{array}$ \\
\hline Campbell $_{t-1}$ & & & & $\begin{array}{l}0.3331 \\
(85.15)^{* * *}\end{array}$ & $\begin{array}{l}0.0320 \\
(9.58)^{* * *}\end{array}$ & $\begin{array}{l}-0.4661 \\
(-12.34)^{* *}\end{array}$ \\
\hline Controls & Yes & Yes & Yes & Yes & Yes & Yes \\
\hline \multirow{2}{*}{$\begin{array}{l}\text { Sample size } \\
\text { Sys. weighted } \mathrm{R}^{2}\end{array}$} & \multirow{2}{*}{\multicolumn{3}{|c|}{$\begin{array}{r}34,896 \\
0.6016 \\
\end{array}$}} & \multirow{2}{*}{\multicolumn{3}{|c|}{$\begin{array}{r}34,890 \\
0.5893 \\
\end{array}$}} \\
\hline & & & & & & \\
\hline \multicolumn{7}{|c|}{ Panel B: Auditor Resignations and Causal Relations between Conservatism and Bankruptcy Risk } \\
\hline \multirow{2}{*}{ Independent Variables } & \multicolumn{3}{|c|}{\begin{tabular}{|l|l|} 
Model 1 \\
\end{tabular}} & \multicolumn{3}{|c|}{ Model 2} \\
\hline & $\boldsymbol{E D F}_{t}$ & $U C_{-} P C A_{t}$ & CC_PCA & Campbell $_{t}$ & $U C_{-} P C_{t}$ & CC_PCA \\
\hline Intercept & $\begin{array}{l}0.2311 \\
(4.32)^{* * *}\end{array}$ & $\begin{array}{l}0.0116 \\
(0.32)\end{array}$ & $\begin{array}{l}3.0028 \\
(6.98)^{* * *}\end{array}$ & $\begin{array}{l}0.3840 \\
(7.19)^{* * *}\end{array}$ & $\begin{array}{l}0.0011 \\
(0.03)\end{array}$ & $\begin{array}{l}2.9924 \\
(7.01)^{* * *}\end{array}$ \\
\hline$U C_{-} P C A_{t-1}$ & $\begin{array}{l}-0.1108 \\
(-2.79) * * *\end{array}$ & $\begin{array}{l}0.6775 \\
(26.99)^{* * *}\end{array}$ & $\begin{array}{l}-0.0284 \\
(-0.09)\end{array}$ & $\begin{array}{l}-0.0593 \\
(-1.49)\end{array}$ & $\begin{array}{l}0.6774 \\
(27.05)^{* * *}\end{array}$ & $\begin{array}{l}-0.0419 \\
(-0.14)\end{array}$ \\
\hline$U C_{-} P C A_{t-1} * A u d_{-}$resign $n_{t-1}$ & $\begin{array}{l}-0.0400 \\
(-0.73)\end{array}$ & & & $\begin{array}{l}0.0062 \\
(0.11)\end{array}$ & & \\
\hline$C C_{-} P C A_{t-1}$ & $(-0.73)$ & $\begin{array}{l}0.0052 \\
(1.56)\end{array}$ & $\begin{array}{l}-0.0549 \\
(-1.38)\end{array}$ & $\begin{array}{l}-0.0215 \\
(-3.72) * * *\end{array}$ & $\begin{array}{l}0.0050 \\
(1.49)\end{array}$ & $\begin{array}{l}-0.0545 \\
(-1.36)\end{array}$ \\
\hline$C C \_P C A_{t-1} * A u d \_r e s i g n_{t-1}$ & $\begin{array}{l}-0.0062 \\
(-0.80)\end{array}$ & & & $\begin{array}{l}0.0009 \\
(0.11)\end{array}$ & & \\
\hline$E D F_{t-1}$ & $\begin{array}{l}0.0910 \\
(3.34)^{* * *}\end{array}$ & $\begin{array}{l}0.0235 \\
(0.99)\end{array}$ & $\begin{array}{l}0.0515 \\
(0.18)\end{array}$ & & & \\
\hline$E D F_{t-1} * A u d \_r e s i g n_{t-1}$ & & $\begin{array}{l}0.0792 \\
(2.56)^{* *}\end{array}$ & $\begin{array}{l}0.0407 \\
(0.10)\end{array}$ & & & \\
\hline Campbell $t_{t-1}$ & & & & $\begin{array}{l}0.2751 \\
(10.14)^{* * *}\end{array}$ & $\begin{array}{l}0.0437 \\
(1.84)^{*}\end{array}$ & $\begin{array}{l}0.0965 \\
(0.34)\end{array}$ \\
\hline Campbell $_{t-1} * A u d$ resign $n_{t-1}$ & & & & & $\begin{array}{l}0.0522 \\
(1.67)^{*}\end{array}$ & $\begin{array}{l}-0.1155 \\
(-0.30)\end{array}$ \\
\hline Controls & Yes & Yes & Yes & Yes & Yes & Yes \\
\hline $\begin{array}{l}\text { Sample size } \\
\text { Sys. weighted } \mathrm{R}^{2}\end{array}$ & & $\begin{array}{c}732 \\
0.6782\end{array}$ & & & $\begin{array}{c}732 \\
0.6351\end{array}$ & \\
\hline $\begin{array}{l}\text { The tri-variate VARX (1) model us } \\
B R_{t}=\alpha_{10}+\beta_{11} B R_{t-1}+\gamma_{11} U C_{-} P C A_{t} \\
U C_{-} P C A_{t}=\alpha_{20}+\beta_{21} B R_{t-1}+\gamma_{21} U C \\
C C_{-} P C A_{t}=\alpha_{30}+\beta_{31} B R_{t-1}+\gamma_{31} U C \\
\text { where Exp=SOX and } \text { Aud Resign }\end{array}$ & $\begin{array}{l}\text { this table co } \\
\delta_{1 I} C C_{-} P C A_{t-1} \\
A_{t-1}+\delta_{2 l} C C_{-} \\
A_{t-1}+\delta_{3 l} C C_{-} \\
\text {anels } \mathrm{A} \text { and } \overline{\mathrm{E}}\end{array}$ & $\begin{array}{l}\text { sts of the folloy } \\
\theta_{11} \operatorname{Exp}_{t-1} * U C_{-} I \\
A_{t-1}+\theta_{21} \operatorname{Exp}_{t-1} \\
A_{t-1}+\theta_{31} \operatorname{Exp}_{t-1} \\
\text { spectively. } C o\end{array}$ & $\begin{array}{l}\text { ng three equati } \\
C A_{t-1}+\theta_{12} \operatorname{Exp}_{t-} \\
B R_{t-1}+\theta_{22} \operatorname{Exp}_{t-} \\
B R_{t-1}+\theta_{32} \operatorname{Exp}_{t-\mathrm{t}}\end{array}$ & $\begin{array}{l}\text { S: } \\
C C+P C A_{t-1}+\theta_{l} \\
\text { Controls }+\varepsilon_{2 l} \\
\text { Controls }+\varepsilon_{3 l}\end{array}$ & $\operatorname{Exp}_{t-1}+$ Contro & $+\varepsilon_{11}$ \\
\hline
\end{tabular}




\section{Table 7 Conservatism Gaming and Causal Relations between Unconditional and Conditional Conservatism and Bankruptcy Risk}

This table reports the SUR estimation results for tetra-variate VARX (1) models with bankruptcy risk, unconditional and conditional conservatism and conservatism gaming as dependent variables and their one-period lags as autoregressive vectors. Bankruptcy risk measures are EDF and Campbell. Model 1 uses EDF, UC_PCA, CC_PCA and Esmooth as the autoregressive vector; Model 2 uses Campbell, UC_PCA, CC_PCA and Esmooth as the autoregressive vector. Model details are provided below.

\begin{tabular}{|c|c|c|c|c|c|c|c|c|}
\hline \multirow{2}{*}{$\begin{array}{l}\text { Independent } \\
\text { Variables } \\
\end{array}$} & \multicolumn{4}{|c|}{ Model 1} & \multicolumn{4}{|c|}{ Model 2} \\
\hline & \multirow{2}{*}{$\begin{array}{l}\boldsymbol{E D F _ { \boldsymbol { t } }} \\
0.4339 \\
(27.76)^{* * *}\end{array}$} & \multicolumn{2}{|c|}{$U C_{-} P C A_{t} C C_{-} P C A_{t}$} & \multirow{2}{*}{\begin{tabular}{l|} 
Esmooth $_{\boldsymbol{t}}$ \\
0.1992 \\
$(15.07)^{* * *}$
\end{tabular}} & \multirow{2}{*}{\begin{tabular}{|l|} 
Campbell \\
0.4795 \\
$(29.57)^{* * *}$
\end{tabular}} & \multicolumn{2}{|c|}{$U C \_P C A_{t} C C_{-} P C A_{t}$} & \multirow{2}{*}{$\begin{array}{l}\text { Esmooth }_{\boldsymbol{t}} \\
0.1979 \\
(15.18)^{* * *}\end{array}$} \\
\hline Intercept & & $\begin{array}{l}0.0191 \\
(3.62)^{* * *}\end{array}$ & $\begin{array}{l}2.9232 \\
(43.49)^{* * *}\end{array}$ & & & $\begin{array}{l}0.0214 \\
(4.11)^{* * *}\end{array}$ & $\begin{array}{l}.0107 \\
(45.50)^{* * *}\end{array}$ & \\
\hline$U C_{-} P C A_{t-1}$ & $\begin{array}{l}-0.0463 \\
(-8.94)^{* * *}\end{array}$ & $\begin{array}{l}0.6789 \\
(185.10)^{* * *}\end{array}$ & $\begin{array}{l}0.1222 \\
(2.62)^{* * *}\end{array}$ & $\begin{array}{l}-0.0264 \\
(-2.87)^{* * *}\end{array}$ & $\begin{array}{l}-0.0215 \\
(-4.02)^{* * *}\end{array}$ & $\begin{array}{l}0.6792 \\
(185.08)^{* * *}\end{array}$ & $\begin{array}{l}0.0823 \\
(1.77)^{*}\end{array}$ & $\begin{array}{l}-0.0261 \\
(-2.84)^{* * *}\end{array}$ \\
\hline$C C_{-} P C A_{t-1}$ & $\begin{array}{l}-0.0077 \\
(-13.34)^{* * *}\end{array}$ & $\begin{array}{l}0.0018 \\
(4.44)^{* * * *}\end{array}$ & $\begin{array}{l}-0.0129 \\
(-2.46)^{* *}\end{array}$ & $\begin{array}{l}0.0010 \\
(0.96)\end{array}$ & $\begin{array}{l}-0.0110 \\
(-18.33)^{* * *}\end{array}$ & $\begin{array}{l}0.0016 \\
(3.93)^{* * *}\end{array}$ & $\begin{array}{l}-0.0077 \\
(-1.46)\end{array}$ & $\begin{array}{l}0.0009 \\
(0.91)\end{array}$ \\
\hline Esmooth $_{t-1}$ & $\begin{array}{l}0.0009 \\
(0.42)\end{array}$ & $\begin{array}{l}-0.0029 \\
(-1.94)^{*}\end{array}$ & $\begin{array}{l}-0.0424 \\
(-2.20)^{* *}\end{array}$ & $\begin{array}{l}0.7185 \\
(189.28)^{* * *}\end{array}$ & $\begin{array}{l}-0.0041 \\
(-1.85)^{*}\end{array}$ & $\begin{array}{l}-0.0030 \\
(-1.98)^{* *}\end{array}$ & $\begin{array}{l}-0.0451 \\
(-2.34)^{* *}\end{array}$ & $\begin{array}{l}0.7186 \\
(189.30)^{* * *}\end{array}$ \\
\hline$E D F_{t-1}$ & $\begin{array}{l}0.2510 \\
(60.04)^{* * *}\end{array}$ & $\begin{array}{l}0.0405 \\
(13.71)^{* * *}\end{array}$ & $\begin{array}{l}-0.2684 \\
(-7.15)^{* * * *}\end{array}$ & $\begin{array}{l}-0.0023 \\
(-0.31)\end{array}$ & & & & \\
\hline Campbell $_{t-1}$ & & & & & $\begin{array}{l}0.3405 \\
(82.13) * * *\end{array}$ & $\begin{array}{l}0.0396 \\
(14.01) * * *\end{array}$ & $\begin{array}{l}-0.4287 \\
(-11.95)^{* * *}\end{array}$ & $\begin{array}{l}-0.0003 \\
(-0.05) \\
\end{array}$ \\
\hline$\overline{L n}(M V)_{t}$ & $\begin{array}{l}-0.0374 \\
(-61.02)^{* * *}\end{array}$ & $\begin{array}{l}0.0157 \\
(37.62)^{* * *}\end{array}$ & $\begin{array}{l}-0.2657 \\
(-49.91)^{* * *}\end{array}$ & $\begin{array}{l}-0.0010 \\
(-0.92)\end{array}$ & $\begin{array}{l}-0.0308 \\
(-49.70) * * *\end{array}$ & $\begin{array}{l}0.0151 \\
(37.45)^{* * *}\end{array}$ & $\begin{array}{l}-0.2675 \\
(-52.21)^{* * *}\end{array}$ & $\begin{array}{l}-0.0009 \\
(-0.85)\end{array}$ \\
\hline Leverage $_{t}$ & $\begin{array}{l}0.6472 \\
(89.93)^{* * *}\end{array}$ & $\begin{array}{l}-0.0685 \\
(-13.93)^{* * *}\end{array}$ & $\begin{array}{l}0.2969 \\
(4.74)^{* * *}\end{array}$ & $\begin{array}{l}0.0516 \\
(4.19)^{* * *}\end{array}$ & $\begin{array}{l}0.4698 \\
(63.90)^{* * * *}\end{array}$ & $\begin{array}{l}-0.0680 \\
(-13.88)^{* * *}\end{array}$ & $\begin{array}{l}0.3835 \\
(6.16)^{* * *}\end{array}$ & $\begin{array}{l}0.0505 \\
(4.12)^{* * *}\end{array}$ \\
\hline$R O A_{t}$ & $\begin{array}{l}-0.4005 \\
(-30.75)^{* * *}\end{array}$ & $\begin{array}{l}-0.2626 \\
(-28.83)^{* * *}\end{array}$ & $\begin{array}{l}-6.4814 \\
(-55.91)^{* * *}\end{array}$ & $\begin{array}{l}0.0991 \\
(4.35)^{* * *}\end{array}$ & $\begin{array}{l}-0.9346 \\
(-68.24)^{* * *}\end{array}$ & $\begin{array}{l}-0.2513 \\
(-27.21)^{* * *}\end{array}$ & $\begin{array}{l}-6.6653 \\
(-56.80)^{* * *}\end{array}$ & $\begin{array}{l}0.1003 \\
(4.34)^{* * *}\end{array}$ \\
\hline$S T D \_R_{e} t_{t}$ & $\begin{array}{l}0.3233 \\
(74.66)^{* * *}\end{array}$ & & & & $\begin{array}{l}0.1706 \\
(38.25)^{* * * *}\end{array}$ & & & \\
\hline Cash $_{t}$ & $\begin{array}{l}-0.0341 \\
(-3.58)^{* * * *}\end{array}$ & & & & $\begin{array}{l}-0.3149 \\
(-31.66)^{* * *}\end{array}$ & & & \\
\hline$\Delta$ Cash $_{t}$ & $\begin{array}{l}-0.0685 \\
(-4.81)^{* * *}\end{array}$ & & & & $\begin{array}{l}-0.1386 \\
(-9.38)^{* * *}\end{array}$ & & & \\
\hline Rate $_{t}$ & $\begin{array}{l}-2.0966 \\
(-11.23)^{* * *}\end{array}$ & & & & $\begin{array}{l}-1.1019 \\
(-5.70)^{* * *}\end{array}$ & & & \\
\hline Inten_RD $D_{t}$ & $\begin{array}{l}-0.0005 \\
(-0.89)\end{array}$ & $\begin{array}{l}0.0023 \\
(6.15)^{* * *}\end{array}$ & $\begin{array}{l}-0.0080 \\
(-1.70)^{*}\end{array}$ & & $\begin{array}{l}-0.0010 \\
(-1.93)^{* *}\end{array}$ & $\begin{array}{l}0.0023 \\
(6.28)^{* * *}\end{array}$ & $\begin{array}{l}-0.0085 \\
(-1.81)^{*}\end{array}$ & \\
\hline Volatility_ROA $A_{t}$ & & & & $\begin{array}{l}-0.0110 \\
(-0.48)\end{array}$ & & & & $\begin{array}{l}-0.0102 \\
(-0.45)\end{array}$ \\
\hline $\begin{array}{l}\text { Year and Ind Dum } \\
F \text {-statistic }\end{array}$ & $\begin{array}{l}\text { Yes } \\
133.83 * * *\end{array}$ & $\begin{array}{l}\text { Yes } \\
188.03 * * *\end{array}$ & $\begin{array}{l}\text { Yes } \\
51.10^{* * *}\end{array}$ & Yes & $\begin{array}{l}\text { Yes } \\
179.80 * * *\end{array}$ & $\begin{array}{l}\text { Yes } \\
196.44 * * *\end{array}$ & $\begin{array}{l}\text { Yes } \\
142.80^{* * *}\end{array}$ & Yes \\
\hline $\begin{array}{l}\text { Sample size } \\
\text { Sys. weighted } \mathrm{R}^{2}\end{array}$ & & & $\begin{array}{l}361 \\
080 \\
\end{array}$ & & & $\begin{array}{l}32,3 \\
0.59 \\
\end{array}$ & & \\
\hline $\begin{aligned} B R_{t}=\alpha_{10}+\beta_{11} B R_{t-1}+\gamma_{1} & \\
U_{-} P C A_{t}= & \alpha_{20}+\beta_{21} B R_{t} \\
C C_{-} P C A_{t}= & \alpha_{30}+\beta_{31} B R_{t} \\
\text { Esmooth }_{t}= & \alpha_{40}+\beta_{41} B R_{t} \\
& +\alpha_{44} \text { Volatili } \\
\text { where } B R= & E D F \text { and } C c\end{aligned}$ & $\begin{array}{l}+\gamma_{31} U C_{-} P C A_{t} \\
-\gamma_{41} U C_{-} P C A_{t} \\
R O A_{t}+\sum \alpha_{4 j} I \\
\text { pbell in Mode }\end{array}$ & $\begin{array}{l}{ }_{11} C C_{-} P C A_{t-1}+ \\
t_{-1-1}+\bar{\delta}_{21} C C_{-} P C \\
t-1+\delta_{31} C C_{-} P C \\
-1+\delta_{41} C C_{-} P C \\
\text { Ind_Dum }{ }_{j}+\sum \alpha \\
\text { els } 1 \text { and 2, res }\end{array}$ & $\begin{array}{l}C A_{t-1}+\theta_{21} E s m \\
C A_{t-1}+\theta_{31} E s m \\
A_{t-1}+\theta_{41} E s m\end{array}$ & $\begin{array}{l}+ \text { Controls }+ \\
\text { ooth }_{t-1}+\text { Cont } \\
\text { ooth }_{t-1}+\text { Cont } \\
\text { ooth }_{t-1}+\alpha_{41} \text { Let } \\
+\varepsilon_{41}\end{array}$ & $\begin{array}{l}\text { equations: } \\
\varepsilon_{11} \\
\text { trols }+\varepsilon_{21} \\
\text { trols }+\varepsilon_{31} \\
\text { verage }_{t}+\alpha_{42} R\end{array}$ & $t_{t}+\alpha_{43} L n$ & t & $\begin{array}{l}(10) \\
(11) \\
(12) \\
(13)\end{array}$ \\
\hline
\end{tabular}


Figure 1

\section{Bankruptcy Timeline}

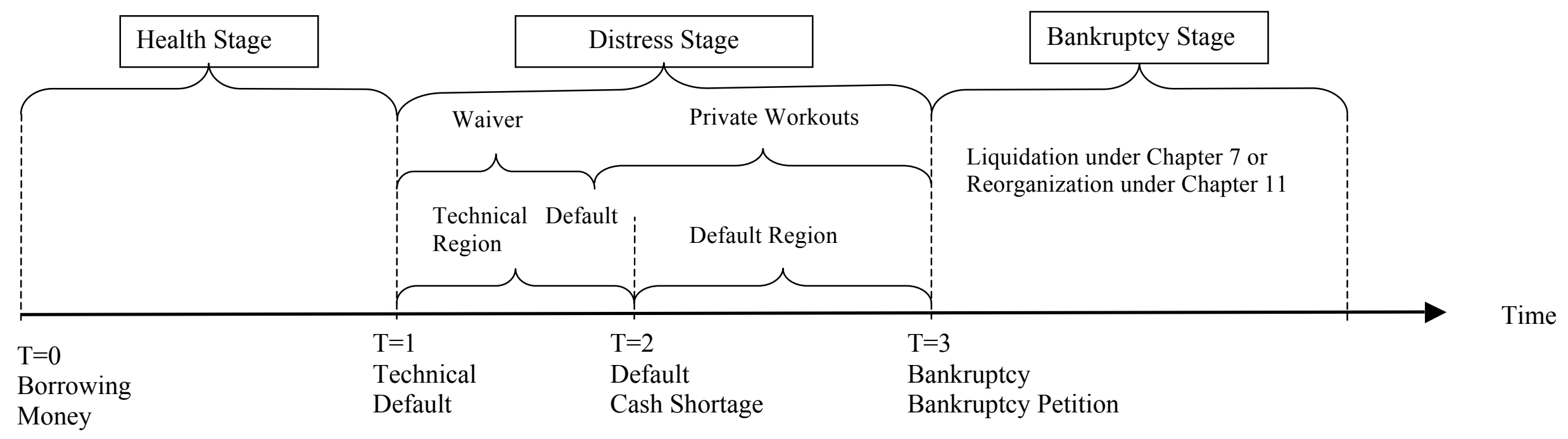




\section{Appendix A Causal Relations between Unconditional Conservatism and Bankruptcy Risk and between Conditional Conservatism and Bankruptcy Risk}

This appendix reports estimation models and results for examining relations between unconditional conservatism and bankruptcy risk using the bi-variate VARX (1) model consisting of equations (1a) and (2a) to test hypotheses $\mathrm{H} 1 \mathrm{a}$ and $\mathrm{H} 2 \mathrm{a}$ :

$$
\begin{aligned}
& B R_{t}=\alpha_{10}+\beta_{11} B R_{t-1}+\gamma_{11} U C_{t-1}+\text { Controls }_{t}+\varepsilon_{11} \\
& U C_{t}=\alpha_{20}+\beta_{21} B R_{t-1}+\gamma_{21} U C_{t-1}+\text { Controls }_{t}+\varepsilon_{21},
\end{aligned}
$$

where $U C$ refers to an unconditional conservatism metric $U C_{-} A C C_{1}, U C_{-} B M, U C_{-} R E S$ or $U C_{-} P C A$, and $B R$ refers to a bankruptcy risk measure $E D F$ or Campbell. The autoregressive vector includes $B R_{t-1}$ and $U C_{t-1}$. Exogenous Controls C $_{t}$ in equations (1b) and (2b) are the same as in equations (3) and (4), respectively, where H1a and $\mathrm{H} 1 \mathrm{~b}$ predict that $\gamma 11<0$ and $\beta 21>0$, respectively.

\section{Table A.1 Causal Relations between Unconditional Conservatism and Bankruptcy Risk}

This table reports SUR estimation results for bi-variate VARX (1) equations (1b) and (2b) for unconditional conservatism. Panel A (Panel B) presents results for models using EDF (Campbell) bankruptcy risk measure. Unconditional conservatism measures are $U C_{-} P C A$, UC_BM, UC_ACC and $U C_{-} R E S$. Model details are provided below.

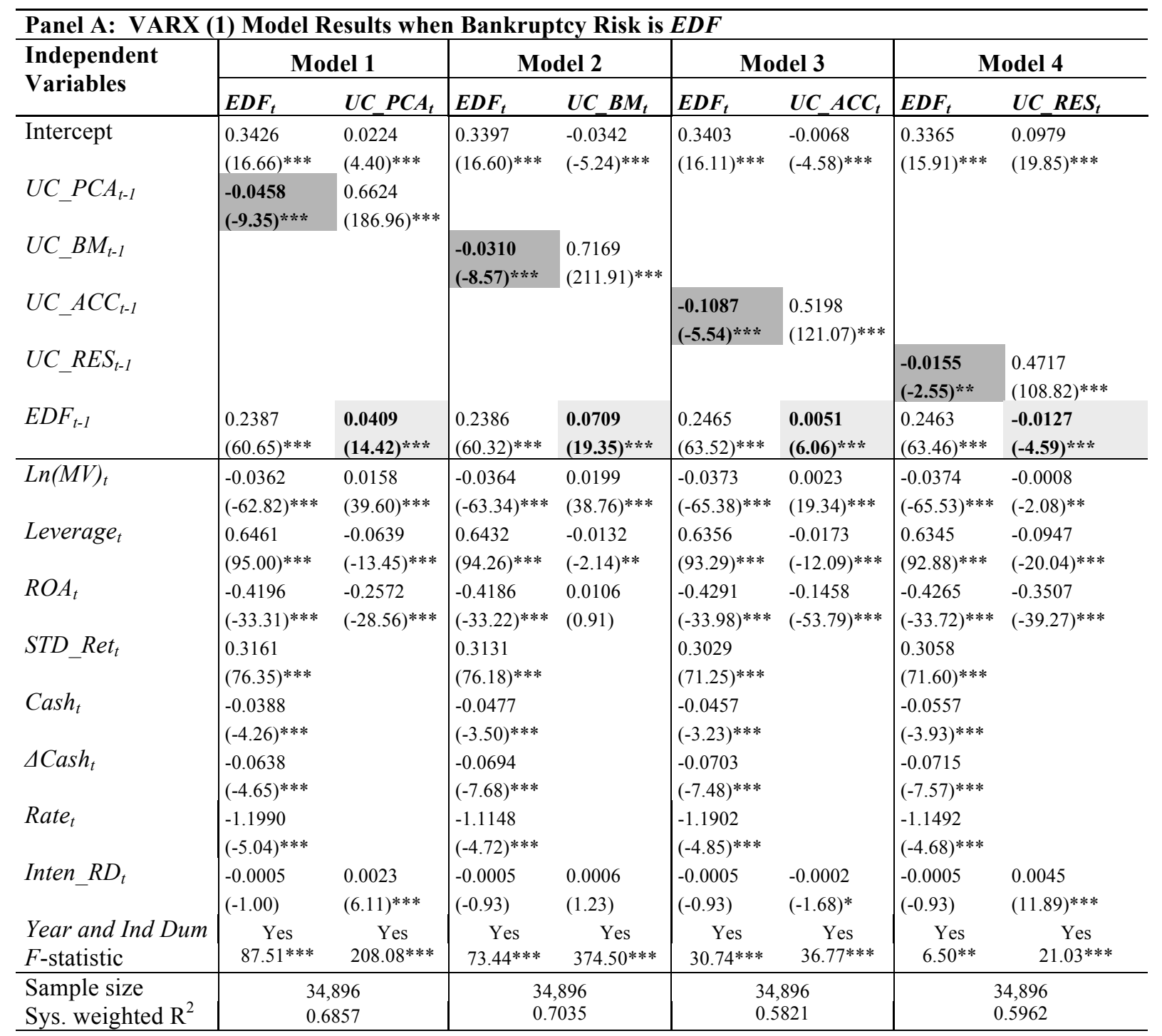

\begin{tabular}{|c|c|c|c|c|c|c|c|c|}
\hline \multirow{2}{*}{$\begin{array}{l}\text { Independent } \\
\text { Variables }\end{array}$} & \multicolumn{2}{|c|}{ Model 1} & \multicolumn{2}{|c|}{ Model 2} & \multicolumn{2}{|c|}{ Model 3} & \multicolumn{2}{|c|}{ Model 4} \\
\hline & Campbell & $U C_{-} P C A_{t}$ & Campbell & $U C_{-} B M_{t}$ & Campbell $_{t}$ & $U C_{-} A C C_{t}$ & Campbell & $U C_{-} R E S_{t}$ \\
\hline Intercept & $\begin{array}{l}0.3726 \\
(17.43)^{* * *}\end{array}$ & $\begin{array}{l}0.0347 \\
(6.66) * * *\end{array}$ & $\begin{array}{l}0.3672 \\
(17.32)^{* * * *}\end{array}$ & $\begin{array}{l}-0.0351 \\
(-5.48) * * *\end{array}$ & $\begin{array}{l}0.3751 \\
(17.12)^{* * *}\end{array}$ & $\begin{array}{l}-0.0059 \\
(-4.03)^{* * *}\end{array}$ & $\begin{array}{l}0.3717 \\
(16.98)^{* * *}\end{array}$ & $\begin{array}{l}0.0668 \\
(19.45)^{* * *}\end{array}$ \\
\hline
\end{tabular}

Panel B: VARX (1) Model Results when Bankruptcy Risk is Campbell 


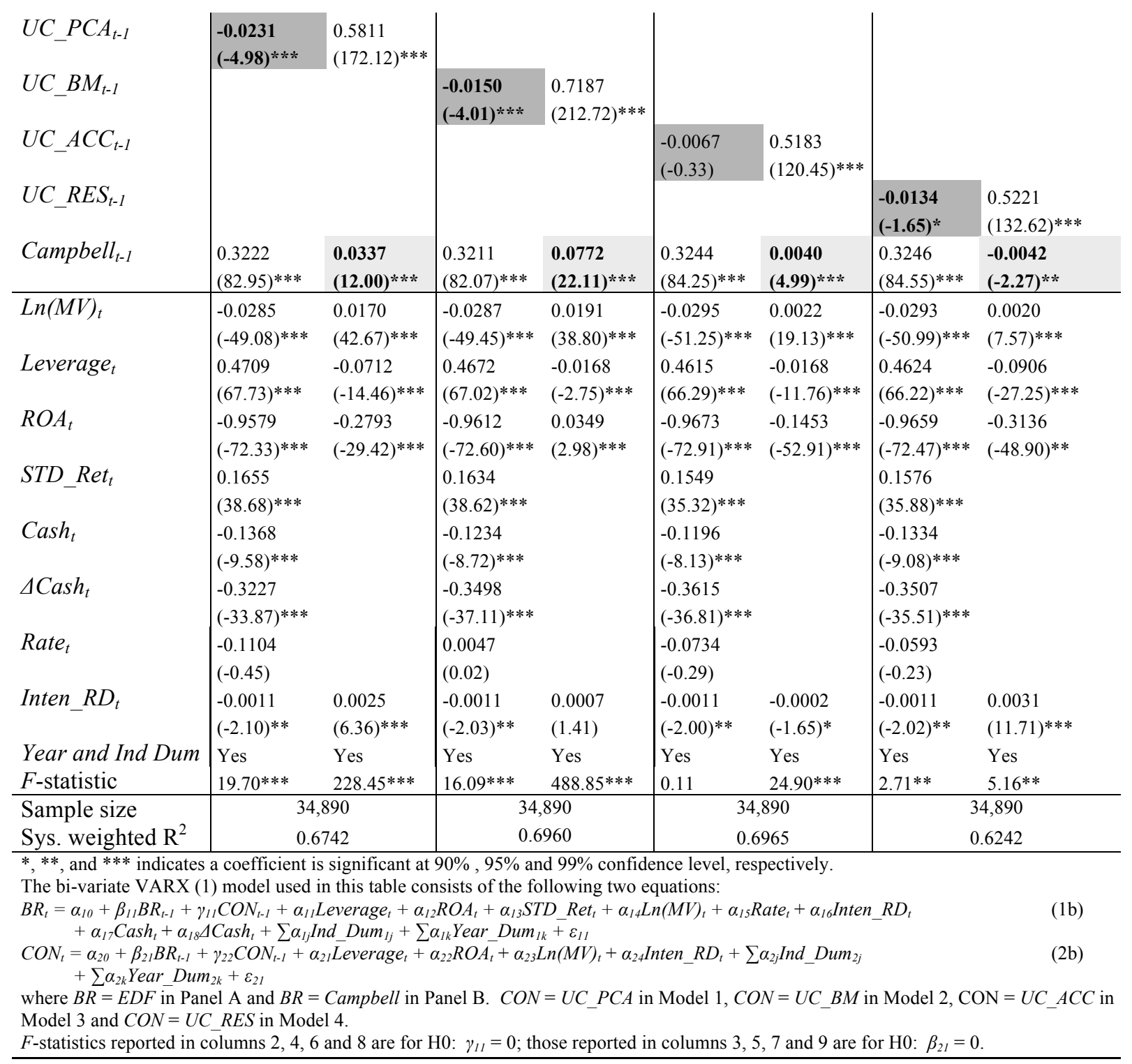

Panel A of Table A.1 reveals that all four measures of unconditional conservatism, $U C_{-} P C_{t-1}, U C_{-} B M_{t-1}$, $U C_{-} A C C_{t-1}$, and $U C_{-} R E S_{t-l}$, are significantly negatively associated with the subsequent bankruptcy risk as measured by $E D F_{t}$; Panel B reports the same pattern for Campbell. For the null hypothesis that the predictor coefficients for $E D F_{t}$ and Campbell $_{t}$ are equal to zero, $F$-statistics are all significant beyond the $95 \%$ confidence level except for $U C_{-} A C C_{t-1}$ in Panel B. These findings support hypothesis H1a in suggesting that the cash enhancing and informational roles of unconditional conservatism lowers subsequent bankruptcy risk. Panel A of Table A.1 further shows that $E D F_{t-1}$ and Campbell t-l $_{\text {are }}$ significantly positively associated with subsequent unconditional conservatism except for $U C R E S$, suggesting that prior bankruptcy risk Granger-causes subsequent unconditional conservatism, consistent with hypothesis H1b. UC_RES $S_{t}$ exhibits negative coefficients ( $t$-statistics) of -0.0127 (-4.59) for $E D F_{t-1}$ in Panel A, and -0.0042 (-2.27) for Campbell Can $_{-1}$ in Panel B. Although this result is inconsistent with $\mathrm{H} 1 \mathrm{~b}$, it is consistent with the intuition that extreme unconditional conservatism in the form of immediate expensing of $R \& D$ and advertising expenditures is detrimental to managers' career motives, and dominates managers' disciplinary concerns and auditor and regulator interests, resulting in disincentives for $U C_{-} R E S_{t}$ as bankruptcy risk rises. Nor does this negative association for $U C_{-} R E S_{t}$ qualitatively change the positive association between bankruptcy risk and subsequent unconditional conservatism exhibited by the combined measure $U C_{-} P C_{t}$. For the null hypothesis that the predictor coefficients for $U C_{-} P C_{t}, U C_{-} B M_{t}$, $U C_{-} A C C_{t}$ and $U C_{-} R E S_{t}$ are equal to zero, $F$-statistics indicate rejection beyond the $95 \%$ confidence level. Overall, these findings support hypothesis $\mathrm{H} 1 \mathrm{~b}$ in suggesting that bankruptcy risk stimulates subsequent unconditional conservatism, consistent with the interests of auditors, creditors and regulators offsetting managers' career motives in the case of unconditional conservatism, as predicted. The signs of the coefficients of the exogenous control variable are also consistent with predictions. For example, $E D F_{t}$ and Campbell $_{t}$ are generally positively associated with Leverage $t_{t}$ and $S T D_{-} R_{e} t_{t}$, and negatively associated with $R O A_{t}, \operatorname{Ln}(M V)_{t}, \operatorname{Rate}_{t}, \operatorname{Cash}_{t}$, $\Delta \operatorname{Cash}_{t}$ and Inten_RD . 


\section{Appendix B Causal Relations between Conditional Conservatism and Bankruptcy Risk}

This appendix reports estimation results regarding relations between conditional conservatism and bankruptcy risk using bi-variate VARX (1). In particular, the following bi-variate VARX (1) model consisting of equations (1b) and $(2 \mathrm{~b})$ tests hypotheses $\mathrm{H} 1 \mathrm{~b}$ and $\mathrm{H} 2 \mathrm{~b}$ regarding causal relations between conditional conservatism and bankruptcy risk:

$$
\begin{aligned}
& B R_{t}=\alpha_{10}+\beta_{11} B R_{t-1}+\gamma_{11} C C_{t-1}+\text { Controls }_{t}+\varepsilon_{11} \\
& C C_{t}=\alpha_{20}+\beta_{21} B R_{t-1}+\gamma_{21} C C_{t-1}+\text { Controls }_{t}+\varepsilon_{21},
\end{aligned}
$$

where $C C$ refers to a conditional conservatism metric $C C_{-} A C M, C C_{-} A R, C C_{-} C R$ or $C C_{-} P C A$, and $B R$ refers to a bankruptcy risk measure $E D F$ or Campbell. The autoregressive vector includes $B R_{t-1}$ and $C C_{t-1}$. Controls in $_{t}$ equations ( $3 b)$ and ( $4 b)$ are the same as in equations (4) and (6), respectively, with the same predictions. H1b and $\mathrm{H} 2 \mathrm{~b}$ predict that $\gamma_{11}<0$ and $\beta_{21}<0$, respectively, and Table B. 1 reports the SUR estimation results.

\section{Table B.1 Causal Relations between Conditional Conservatism and Bankruptcy Risk}

This table reports the SUR estimation results for bi-variate VARX (1) equations (1b) and (2b) for conditional conservatism. Panel A (Panel B) presents results for models using EDF (Campbell) bankruptcy risk measure. Conditional conservatism measurements are $C_{-} P C A, C C_{-} A R, C C_{-} C R$ and $C C_{-} A C M$. Model details are provided below.

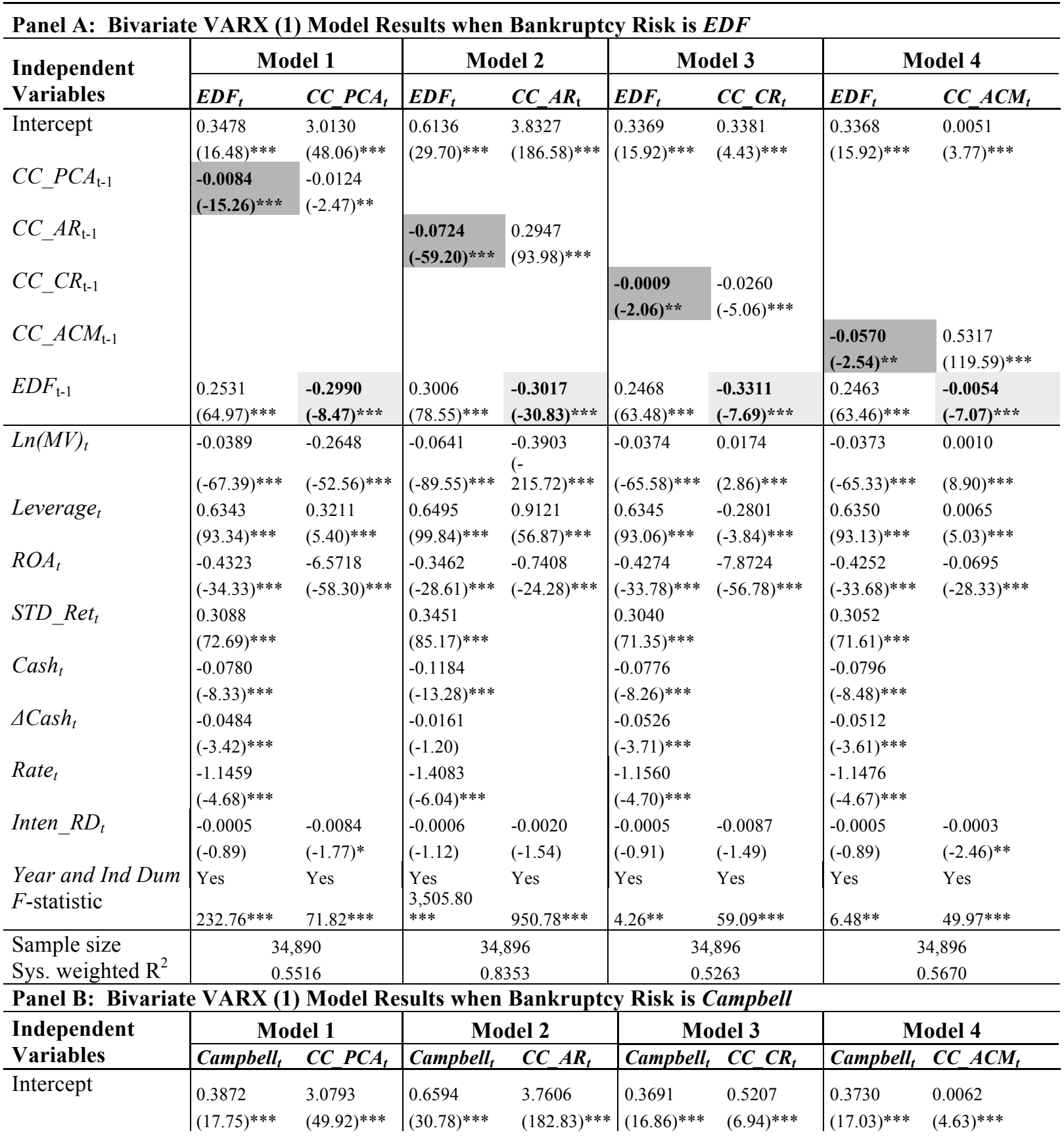




\begin{tabular}{|c|c|c|c|c|c|c|c|c|}
\hline$C C_{-} P C A_{\mathrm{t}-1}$ & $\begin{array}{l}-0.0110 \\
(-19.34)^{* * *}\end{array}$ & $\begin{array}{l}-0.0073 \\
(-1.46)\end{array}$ & & & & & & \\
\hline$C C_{-} A R_{\mathrm{t}-1}$ & & & $\begin{array}{l}-0.0721 \\
(-54.88) * * *\end{array}$ & $\begin{array}{l}0.2883 \\
(88.02)^{* * *}\end{array}$ & & & & \\
\hline$C C_{-} C R_{\mathrm{t}-1}$ & & & & & $\begin{array}{l}-0.0035 \\
(-7.31)^{* * *}\end{array}$ & $\begin{array}{l}-0.0228 \\
(-4.45)^{* * *}\end{array}$ & & \\
\hline$C C_{-} A C M_{\mathrm{t}-1}$ & & & & & & & $\begin{array}{l}-0.0376 \\
(-1.62)\end{array}$ & $\begin{array}{l}0.5323 \\
(119.81)^{* * *}\end{array}$ \\
\hline Campbell $_{\mathrm{t}-1}$ & \begin{tabular}{|l}
0.3353 \\
$(86.81)^{* * *}$
\end{tabular} & $\begin{array}{l}-0.4505 \\
(-13.36)^{* * *}\end{array}$ & $\begin{array}{l}0.4035 \\
(102.64)^{* * *}\end{array}$ & $\begin{array}{l}-0.1588 \\
(-16.29)^{* * *}\end{array}$ & \begin{tabular}{|l}
0.3261 \\
$(84.80)^{* * *}$ \\
\end{tabular} & $\begin{array}{l}-0.6585 \\
(-16.07)^{* * *}\end{array}$ & \begin{tabular}{|l}
0.3241 \\
$(84.42)^{* * *}$
\end{tabular} & $\begin{array}{l}-0.0076 \\
(-10.44)^{* * *}\end{array}$ \\
\hline $\operatorname{Ln}(M V)_{t}$ & $\begin{array}{l}-0.0315 \\
(-54.20)^{* * *}\end{array}$ & $\begin{array}{l}-0.2663 \\
(-55.09)^{* * *}\end{array}$ & $\begin{array}{l}-0.0579 \\
(-78.07)^{* * *}\end{array}$ & \begin{tabular}{l|}
-0.3824 \\
$(-210.63)^{* * *}$
\end{tabular} & $\begin{array}{l}-0.0294 \\
(-51.18)^{* * *}\end{array}$ & $\begin{array}{l}0.0070 \\
(1.21)\end{array}$ & $\begin{array}{l}-0.0294 \\
(-51.12)^{* * *}\end{array}$ & $\begin{array}{l}0.0009 \\
(9.05)^{* * *}\end{array}$ \\
\hline Leverage $_{t}$ & $\begin{array}{l}0.4599 \\
(66.42)^{* * *}\end{array}$ & $\begin{array}{l}0.4018 \\
(6.80)^{* * *}\end{array}$ & $\begin{array}{l}0.4722 \\
(70.79)^{* * *}\end{array}$ & $\begin{array}{l}0.8396 \\
(52.10)^{* * *}\end{array}$ & $\begin{array}{l}0.4603 \\
(66.18)^{* * *}\end{array}$ & $\begin{array}{l}-0.1020 \\
(-1.41)\end{array}$ & $\begin{array}{l}0.4610 \\
(66.23)^{* * *}\end{array}$ & $\begin{array}{l}0.0077 \\
(5.96)^{* * *}\end{array}$ \\
\hline$R O A_{t}$ & $\begin{array}{l}-0.9714 \\
(-73.62) * * *\end{array}$ & $\begin{array}{l}-6.7584 \\
(-59.29)^{* * *}\end{array}$ & $\begin{array}{l}-0.8700 \\
(-67.69)^{* * *}\end{array}$ & $\begin{array}{l}-0.7316 \\
(-23.31)^{* * *}\end{array}$ & $\begin{array}{l}-0.9720 \\
(-73.23)^{* * *}\end{array}$ & $\begin{array}{l}-8.1852 \\
(-58.44)^{* * *}\end{array}$ & $\begin{array}{l}-0.9665 \\
(-72.86)^{* * *}\end{array}$ & $\begin{array}{l}-0.0727 \\
(-29.26)^{* * *}\end{array}$ \\
\hline$S T D \_R_{e} t_{t}$ & $\begin{array}{l}0.1608 \\
(36.82)^{* * *}\end{array}$ & & $\begin{array}{l}0.1480 \\
(35.41)^{* * *}\end{array}$ & & $\begin{array}{l}0.1569 \\
(35.79)^{* * *}\end{array}$ & & $\begin{array}{l}0.1567 \\
(35.70)^{* * *}\end{array}$ & \\
\hline $\mathrm{Cash}_{t}$ & $\begin{array}{l}-0.3607 \\
(-37.00)^{* * *}\end{array}$ & & $\begin{array}{l}-0.3421 \\
(-36.75)^{* * *}\end{array}$ & & $\begin{array}{l}-0.3627 \\
(-37.05)^{* * *}\end{array}$ & & $\begin{array}{l}-0.3665 \\
(-37.42)^{* * *}\end{array}$ & \\
\hline$\Delta \operatorname{Cash}_{t}$ & $\begin{array}{l}-0.1209 \\
(-8.27)^{* * *}\end{array}$ & & $\begin{array}{l}-0.1017 \\
(-7.27)^{* * *}\end{array}$ & & $\begin{array}{l}-0.1235 \\
(-8.41)^{* * *}\end{array}$ & & $\begin{array}{l}-0.1227 \\
(-8.35)^{* * *}\end{array}$ & \\
\hline Rate $_{t}$ & $\begin{array}{l}-0.0478 \\
(-0.19)\end{array}$ & & $\begin{array}{l}-0.2909 \\
(-1.20)\end{array}$ & & $\begin{array}{l}-0.0326 \\
(-0.13)\end{array}$ & & $\begin{array}{l}-0.0475 \\
(-0.19)\end{array}$ & \\
\hline Inten_RD $t$ & $\begin{array}{l}-0.0010 \\
(-1.95)^{* *}\end{array}$ & $\begin{array}{l}-0.0089 \\
(-1.88)^{*}\end{array}$ & $\begin{array}{l}-0.0011 \\
(-2.21)^{* *}\end{array}$ & $\begin{array}{l}-0.0022 \\
(-1.69)^{*}\end{array}$ & $\begin{array}{l}-0.0011 \\
(-1.97)^{* *}\end{array}$ & $\begin{array}{l}-0.0094 \\
(-1.61)\end{array}$ & $\begin{array}{l}-0.0011 \\
(-1.97)^{* *}\end{array}$ & $\begin{array}{l}-0.0003 \\
(-2.55)^{* *}\end{array}$ \\
\hline $\begin{array}{l}\text { Year and Ind Dum } \\
F \text {-statistic }\end{array}$ & Yes & Yes & $\begin{array}{l}\text { Yes } \\
3,013.92 \\
* * *\end{array}$ & Yes & Yes & Yes & Yes & Yes \\
\hline $\begin{array}{l}\text { Sample size } \\
\text { Sys. weighted } \mathrm{R}^{2}\end{array}$ & \multicolumn{2}{|c|}{\begin{tabular}{|l|}
34,890 \\
0.5300
\end{tabular}} & \multicolumn{2}{|c|}{\begin{tabular}{|l|}
34,890 \\
0.8111 \\
\end{tabular}} & \multicolumn{2}{|c|}{$\begin{array}{l}34,890 \\
0.5043 \\
\end{array}$} & \multicolumn{2}{|c|}{$\begin{array}{l}34,890 \\
0.5471\end{array}$} \\
\hline \multicolumn{9}{|c|}{ 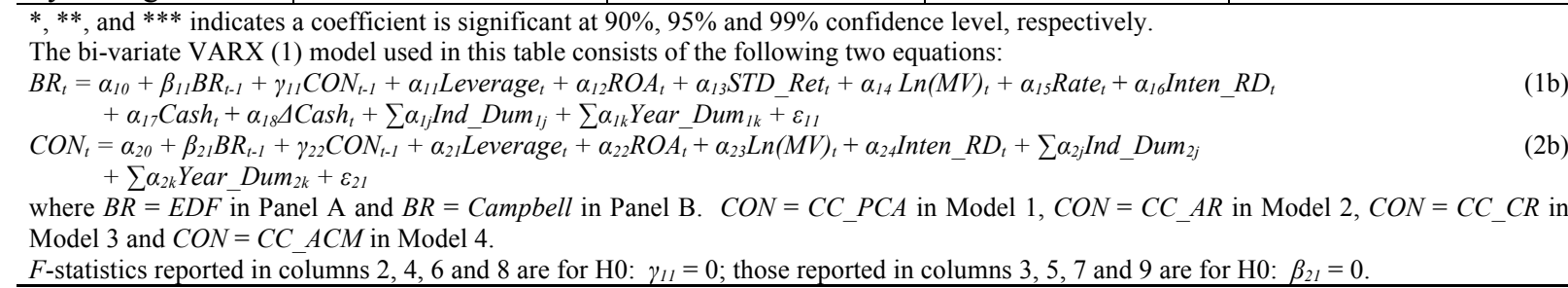 } \\
\hline
\end{tabular}

Panel A of Table B.1 reveals that all four measures of conditional conservatism, $C C_{-} P C A_{t-1}, C C_{-} A R_{t-1}, C C_{-} C R_{t-1}$ and $C C_{-} A C M_{t-1}$, are negatively associated with subsequent bankruptcy risk as measured by $E D F_{t}$, and Panel $\mathrm{B}$ reveals the same pattern for Campbell $l_{t-1}$. For the null hypothesis that the predictor coefficients for $E D F_{t}$ and Campbell $_{t}$ are equal to zero, $F$-statistics are all significant beyond the $90 \%$ confidence level except for $C C_{-} A C M_{t-I}$ in Panel B. These findings suggest that conditional conservatism reduces subsequent bankruptcy risk, consistent with the cash enhancing and informational properties of conditional conservatism as predicted by hypothesis $\mathrm{H} 2 \mathrm{~b}$. Table B.1 further shows that bankruptcy risk metrics $E D F_{t-1}$ and Campbell $t_{t-1}$ are uniformly negatively associated with subsequent conditional conservatism measured by $C C_{-} P C A_{t}, C C_{-} A R_{t}, C C_{-} C R_{t}$ and $C C_{-} A C M_{t}$. These findings suggest that prior bankruptcy risk lowers subsequent conditional conservatism, consistent with hypothesis $\mathrm{H} 2 \mathrm{~b}$. For the null hypothesis that the predictor coefficients for $C_{-} P C A_{t}, C C_{-} A R_{t}, C C_{-} C R_{t}$ and $C C_{-} A C M_{t}$ are equal to zero, $F$-statistics are all significant beyond the $99 \%$ confidence level. These findings support hypothesis $\mathrm{H} 2 \mathrm{~b}$ in suggesting that bankruptcy risk reduces subsequent conditional conservatism, and they are consistent with the notion that although it mitigates subsequent bankruptcy risk, conditional conservatism is resisted by managers whose career motives dominate their disciplinary concerns, as predicted. 